\title{
Diastereoselective Formal [5+2] Cycloaddition of Diazo Arylidene Succinimides-Derived Rhodium Carbenes and Aldehydes: A Route to 2-Benzoxepines
}

\author{
Anna Inyutina, Grigory Kantin, Dmitry Dar'in* and Mikhail Krasavin* \\ Saint Petersburg State University, Saint Petersburg, 199034 Russian Federation \\ E-mails: d.dariin@spbu.ru, $\underline{\text { m.krasavin@spbu.ru }}$ \\ http://www.krasavin-group.org/
}

Table of Contents

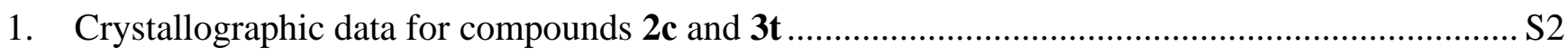

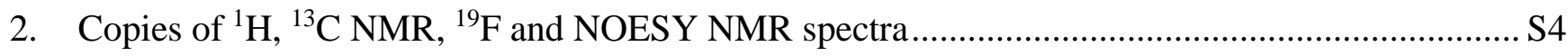




\section{Crystallographic data for compounds $2 \mathrm{c}$ and $3 \mathrm{t}$}

X-ray Single Crystal analysis was performed on Rigaku XtaLAB Synergy-S diffractometer with monochromated $\mathrm{CuK} \alpha$ radiation. Crystal growth was performed by slow evaporation of solution in $n$ hexane/DCM mixture $(2: 1)$ at $5^{\circ} \mathrm{C}$. The crystal was kept at $100 \mathrm{~K}$ during data collection. Using Olex $2^{1}$, the structure was solved with the SHELXT structure solution program using Intrinsic Phasing and refined with the SHELXL ${ }^{2,3}$ refinement package using Least Squares minimization. CCDC 2076285 (2c) and CCDC 2092543 (3t) contain the supplementary crystallographic data for this paper. These data can be obtained free of charge from The Cambridge Crystallographic Data Centre via https://www.ccdc.cam.ac.uk/.

\begin{tabular}{|c|c|}
\hline \multicolumn{2}{|c|}{ Table S1. Crystal data and ORTEP representation for 2c (2076285) } \\
\hline Empirical Formula & $\mathrm{C}_{26} \mathrm{H}_{21} \mathrm{NO}_{4}$ \\
\hline Formula weight & 411.44 \\
\hline Temperature, $\mathbf{K}$ & 100.15 \\
\hline Crystal system & monoclinic \\
\hline Space group & $\mathrm{P} 2{ }_{1} / \mathrm{c}$ \\
\hline $\mathbf{a} / \AA ̊$ & $9.40960(10)$ \\
\hline $\mathbf{b} / \AA$ & $20.9797(2)$ \\
\hline $\mathbf{c} / \AA$ & $10.56750(10)$ \\
\hline$\alpha / \AA$ & 90 \\
\hline$\beta / \AA$ & $105.4800(10)$ \\
\hline$\gamma / \AA$ & 90 \\
\hline Volume $/ \AA^{3}$ & $2010.46(4)$ \\
\hline $\mathbf{Z}$ & 4 \\
\hline$\rho_{\text {calcg}} \mathbf{g} / \mathrm{cm}^{3}$ & 1.359 \\
\hline $\boldsymbol{\mu} / \mathbf{m m}^{-1}$ & 0.744 \\
\hline $\mathbf{F}(\mathbf{0 0 0})$ & 864 \\
\hline Crystal size $/ \mathrm{mm}^{3}$ & $0.16 \times 0.14 \times 0.12$ \\
\hline Radiation & $\mathrm{CuK} \alpha(\lambda=1.54184)$ \\
\hline $2 \Theta$ range for data collection $/^{\circ}$ & 8.43 to 154.018 \\
\hline Index ranges & $-11 \leq \mathrm{h} \leq 11,-26 \leq \mathrm{k} \leq 18,-11 \leq 1 \leq 13$ \\
\hline Reflections collected & 13882 \\
\hline Independent reflections & $4099[$ Rint $=0.0357$, Rsigma $=0.0339]$ \\
\hline Data/restraints/parameters & $4099 / 0 / 281$ \\
\hline Goodness-of-fit on $\mathbf{F}^{2}$ & 1.112 \\
\hline Final $R$ indexes $[I>=2 \sigma(I)]$ & $\mathrm{R} 1=0.0498, \mathrm{wR} 2=0.1230$ \\
\hline Final $\mathbf{R}$ indexes [all data] & $\mathrm{R} 1=0.0527, \mathrm{wR} 2=0.1247$ \\
\hline Largest diff. peak/hole / e $\AA^{-3}$ & $0.24 /-0.32$ \\
\hline
\end{tabular}

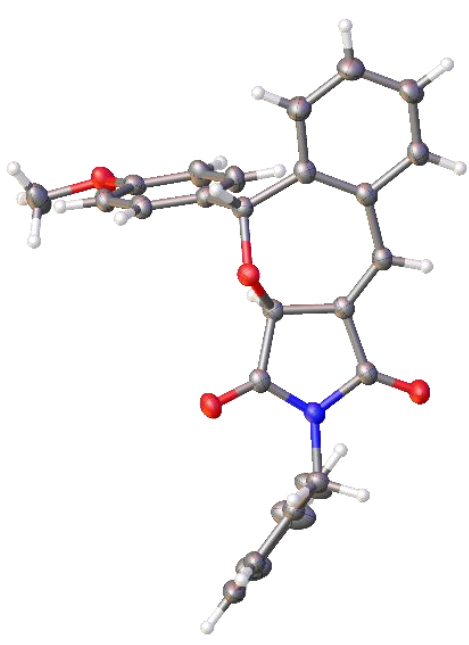

Figure S1. ORTEP representation of compound 2c (thermal ellipsoids are shown at $50 \%$ probability) 


\begin{tabular}{|c|c|}
\hline \multicolumn{2}{|c|}{ Table S2. Crystal data and ORTEP representation for $3 \mathrm{t}$ (2092543) } \\
\hline Empirical Formula & $\mathrm{C}_{43} \mathrm{H}_{31} \mathrm{ClN}_{4} \mathrm{O}_{5}$ \\
\hline Formula weight & 719.17 \\
\hline Temperature, $\mathrm{K}$ & 100.15 \\
\hline Crystal system & monoclinic \\
\hline Space group & $\mathrm{P} 2{ }_{1} / \mathrm{n}$ \\
\hline $\mathbf{a} / \AA$ & $11.4105(3)$ \\
\hline $\mathbf{b} / \AA$ & $15.8118(4)$ \\
\hline $\mathrm{c} / \AA$ & $19.6546(7)$ \\
\hline$\alpha / \AA$ & 90 \\
\hline $\bar{\beta} / \AA$ & 90 \\
\hline$\gamma / \AA$ & 90 \\
\hline Volume $/ \AA^{3}$ & $3546.09(18)$ \\
\hline $\mathbf{Z}$ & 4 \\
\hline$\rho_{\text {calcg}} / \mathbf{c m}^{3}$ & 1.347 \\
\hline $\boldsymbol{\mu} / \mathbf{m m}^{-1}$ & 1.392 \\
\hline $\mathbf{F ( 0 0 0 )}$ & 1496.0 \\
\hline Crystal size $/ \mathbf{m m}^{3}$ & $0.17 \times 0.13 \times 0.1$ \\
\hline Radiation & $\mathrm{CuK} \alpha(\lambda=1.54184)$ \\
\hline $2 \Theta$ range for data collection $/{ }^{\circ}$ & 7.176 to 156.152 \\
\hline Index ranges & $\begin{array}{l}-14 \leq \mathrm{h} \leq 14,-19 \leq \mathrm{k} \leq 17,-24 \leq 1 \\
\leq 24\end{array}$ \\
\hline Reflections collected & 95365 \\
\hline Independent reflections & $\begin{array}{l}7378\left[R_{\text {int }}=0.1077, R_{\text {sigma }}=\right. \\
0.0353]\end{array}$ \\
\hline Data/restraints/parameters & $7378 / 0 / 480$ \\
\hline Goodness-of-fit on $\mathbf{F}^{2}$ & 1.061 \\
\hline Final $R$ indexes $[I>=2 \sigma(I)]$ & $\mathrm{R} 1=0.0601, \mathrm{wR} 2=0.1541$ \\
\hline Final $\mathbf{R}$ indexes [all data] & $\mathrm{R} 1=0.0714, \mathrm{wR} 2=0.1614$ \\
\hline Largest diff. peak/hole / e $\AA^{-3}$ & $0.59 /-0.33$ \\
\hline
\end{tabular}

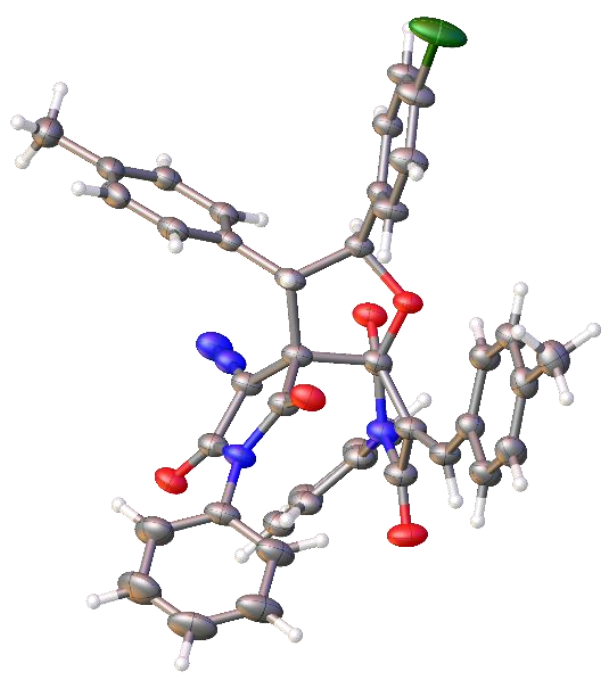

Figure S2. ORTEP representation of compound $\mathbf{3 t}$ (thermal ellipsoids are shown at $50 \%$ probability)

1. Dolomanov, O. V; Bourhis, L. J.; Gildea, R. J.; Howard, J. A. K.; Puschmann, H. OLEX2: A Complete Structure Solution, Refinement and Analysis Program. J. Appl. Crystallogr. 2009, 42, 339-341.

2. Sheldrick, G. M. A Short History of SHELX. Acta Crystallogr. Sect. A 2008, 64, 112-122.

3. Sheldrick, G. M. Crystal Structure Refinement with SHELXL. Acta Crystallogr. Sect. C 2015, 71, 3-8. 


\section{Copies of ${ }^{1} \mathrm{H},{ }^{13} \mathrm{C}$ NMR, ${ }^{19} \mathrm{~F}$ and NOESY NMR spectra}

Copies of ${ }^{1} \mathrm{H}\left(400.13 \mathrm{MHz}, \mathrm{CDCl}_{3}\right)$ and ${ }^{13} \mathrm{C}\left\{{ }^{1} \mathrm{H}\right\}\left(100.61 \mathrm{MHz}, \mathrm{CDCl}_{3}\right)$ spectra of $\mathbf{1 g}$

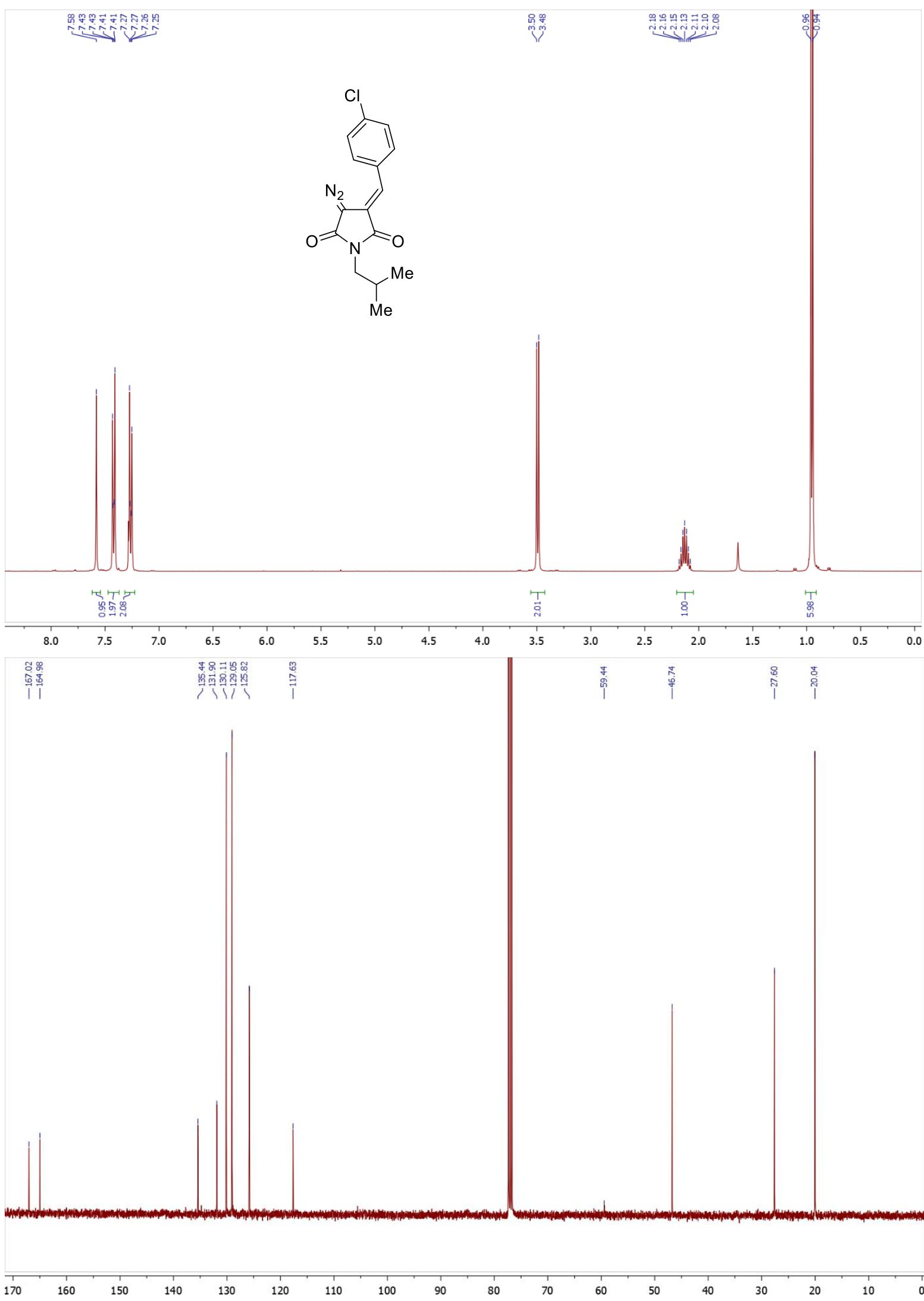


Copies of ${ }^{1} \mathrm{H}\left(400.13 \mathrm{MHz}, \mathrm{CDCl}_{3}\right)$ and ${ }^{13} \mathrm{C}\left\{{ }^{1} \mathrm{H}\right\}\left(100.61 \mathrm{MHz}, \mathrm{CDCl}_{3}\right)$ spectra of $2 \mathrm{a}$

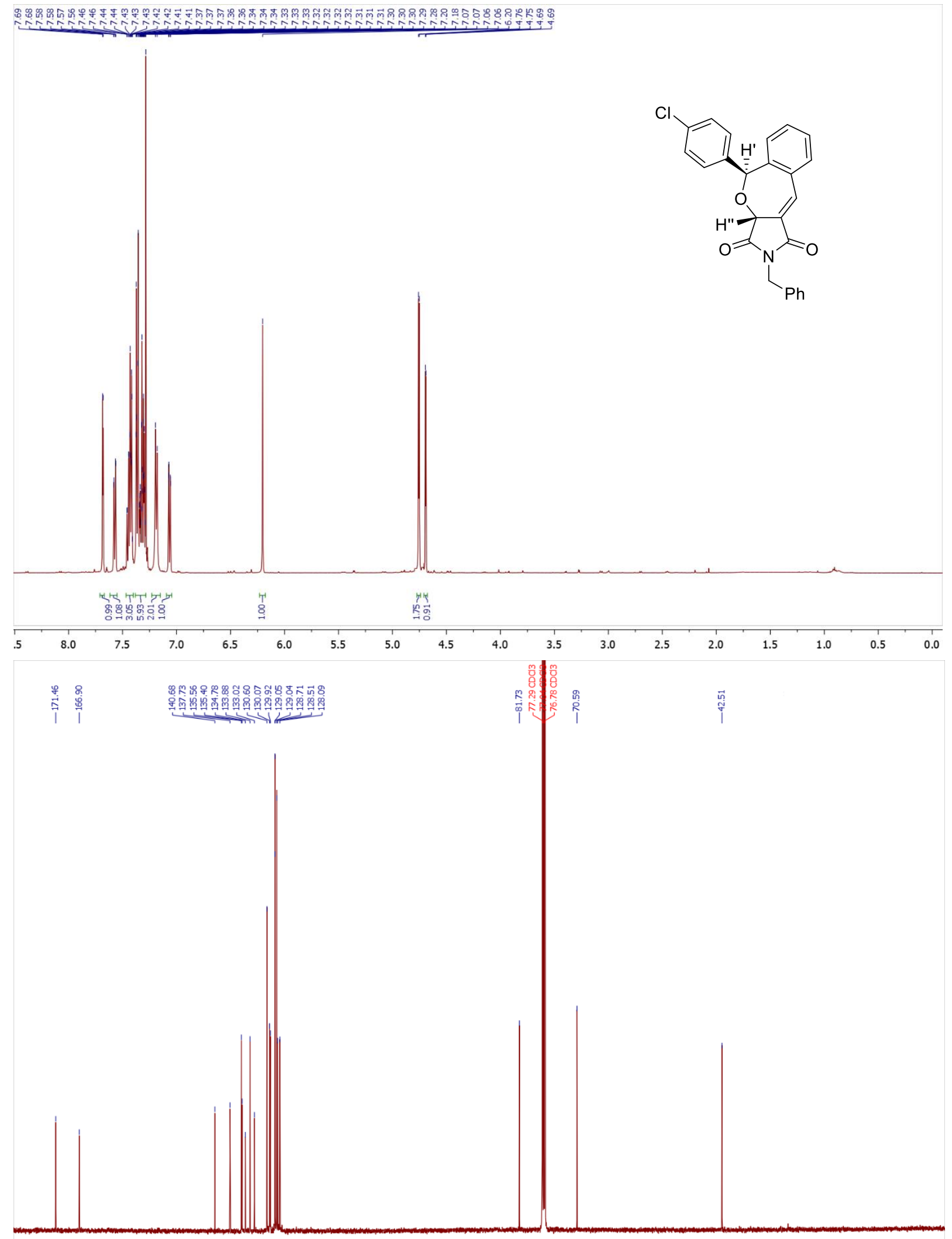

\begin{tabular}{|c|c|c|c|c|c|c|c|c|c|c|c|c|c|c|c|c|}
\hline 170 & 160 & 150 & 140 & 130 & 120 & 110 & 100 & 90 & 80 & 70 & 60 & 50 & 40 & 30 & 20 & 10 \\
\hline
\end{tabular}


Copy of NOESY spectrum of $\mathbf{2 a}$

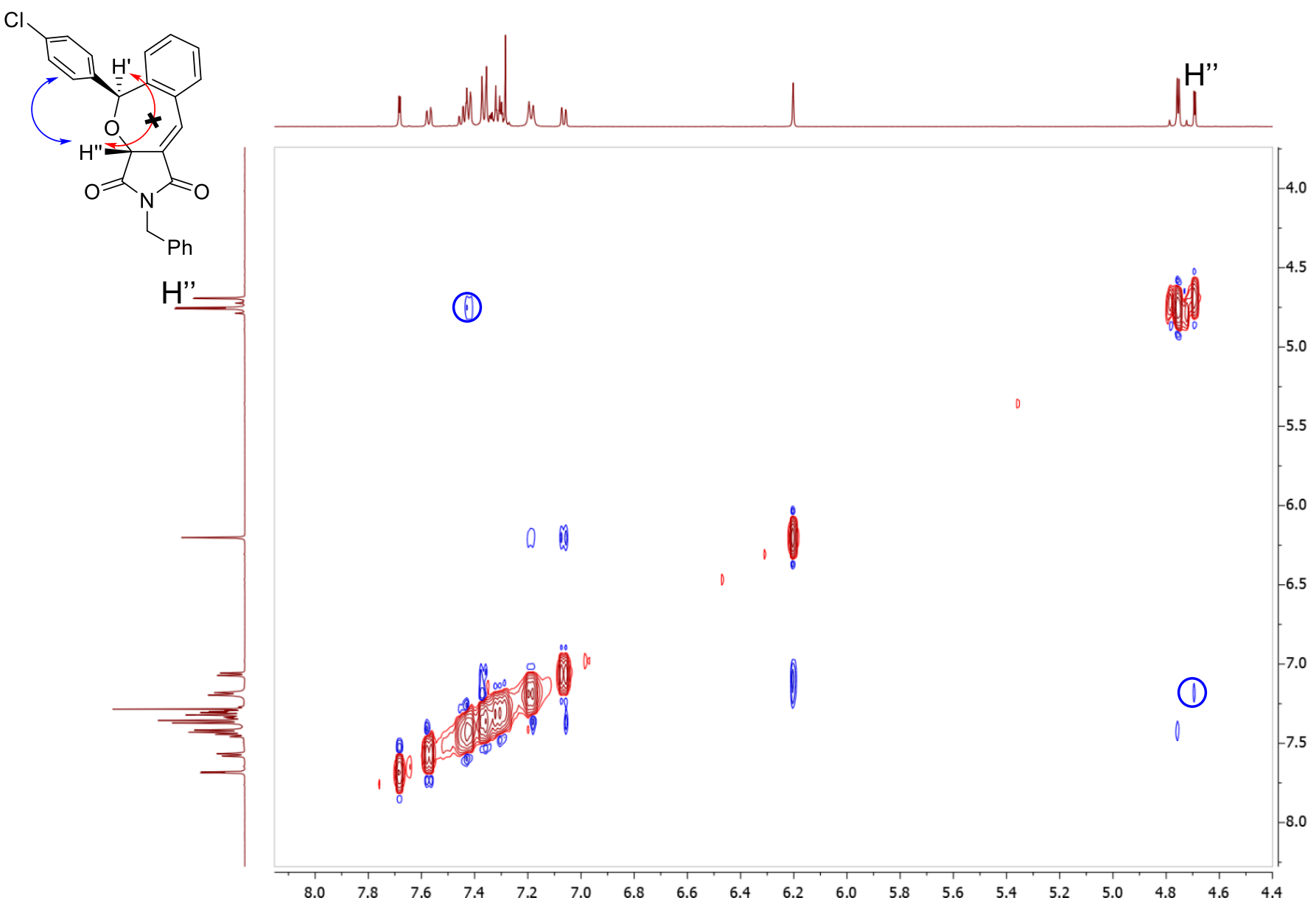


Copies of ${ }^{1} \mathrm{H}\left(400.13 \mathrm{MHz}, \mathrm{CDCl}_{3}\right)$ and ${ }^{13} \mathrm{C}\left\{{ }^{1} \mathrm{H}\right\}\left(100.61 \mathrm{MHz}, \mathrm{CDCl}_{3}\right)$ spectra of 3a
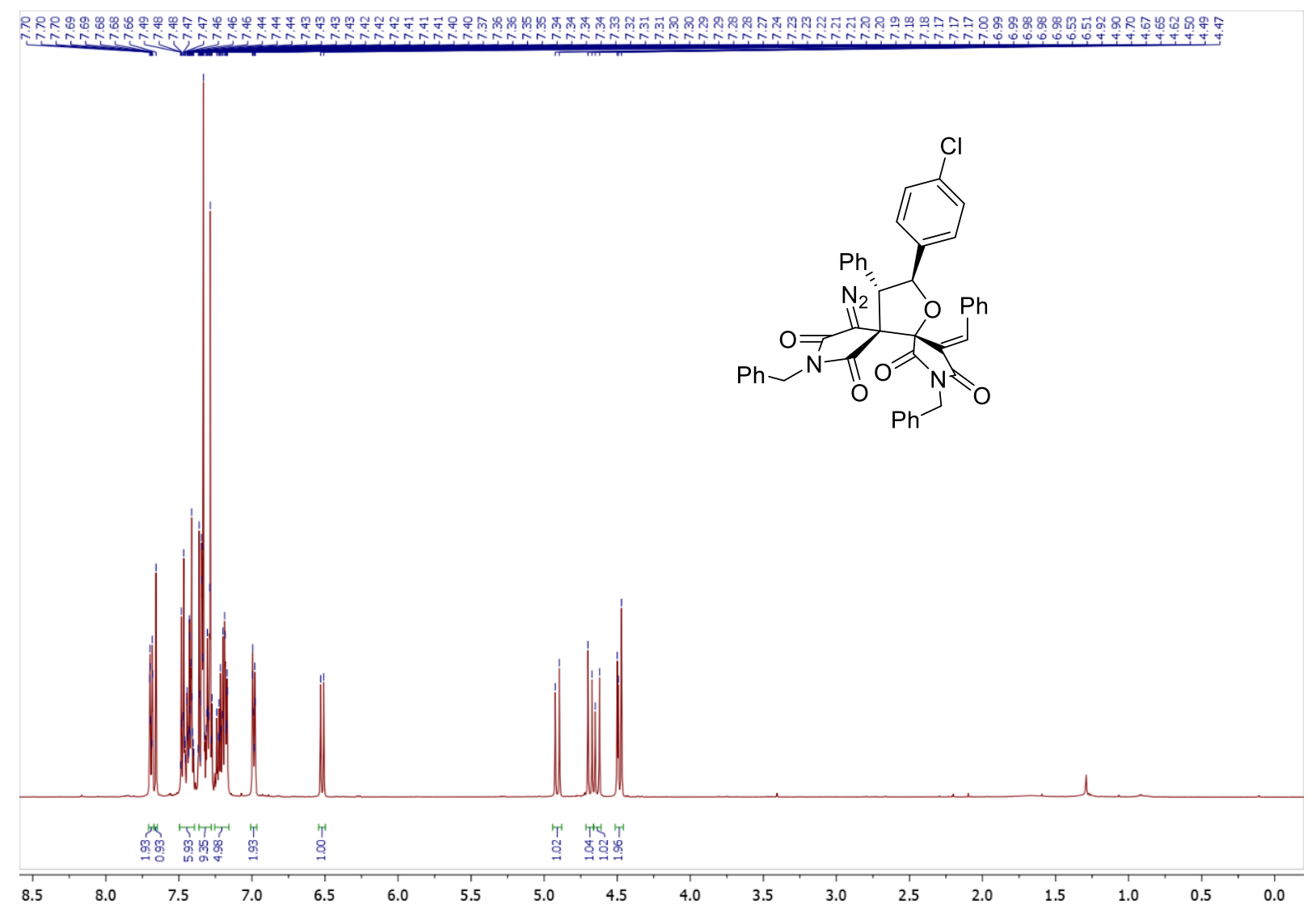

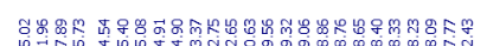

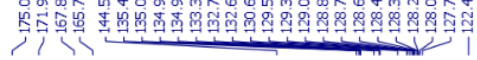
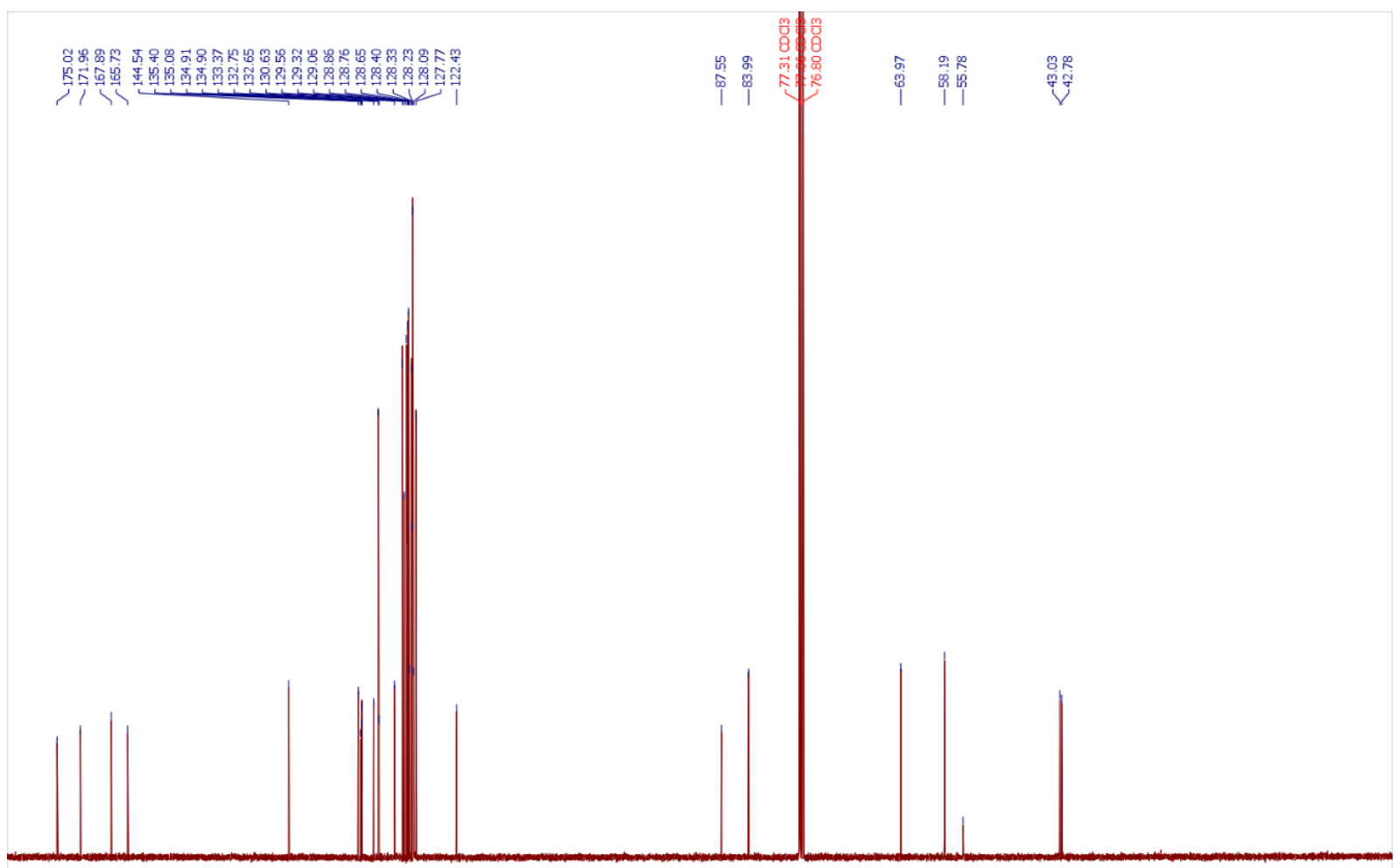
Copies of ${ }^{1} \mathrm{H}\left(400.13 \mathrm{MHz}, \mathrm{CDCl}_{3}\right)$ and ${ }^{13} \mathrm{C}\left\{{ }^{1} \mathrm{H}\right\}\left(100.61 \mathrm{MHz}, \mathrm{CDCl}_{3}\right)$ spectra of $\mathbf{2 b}$
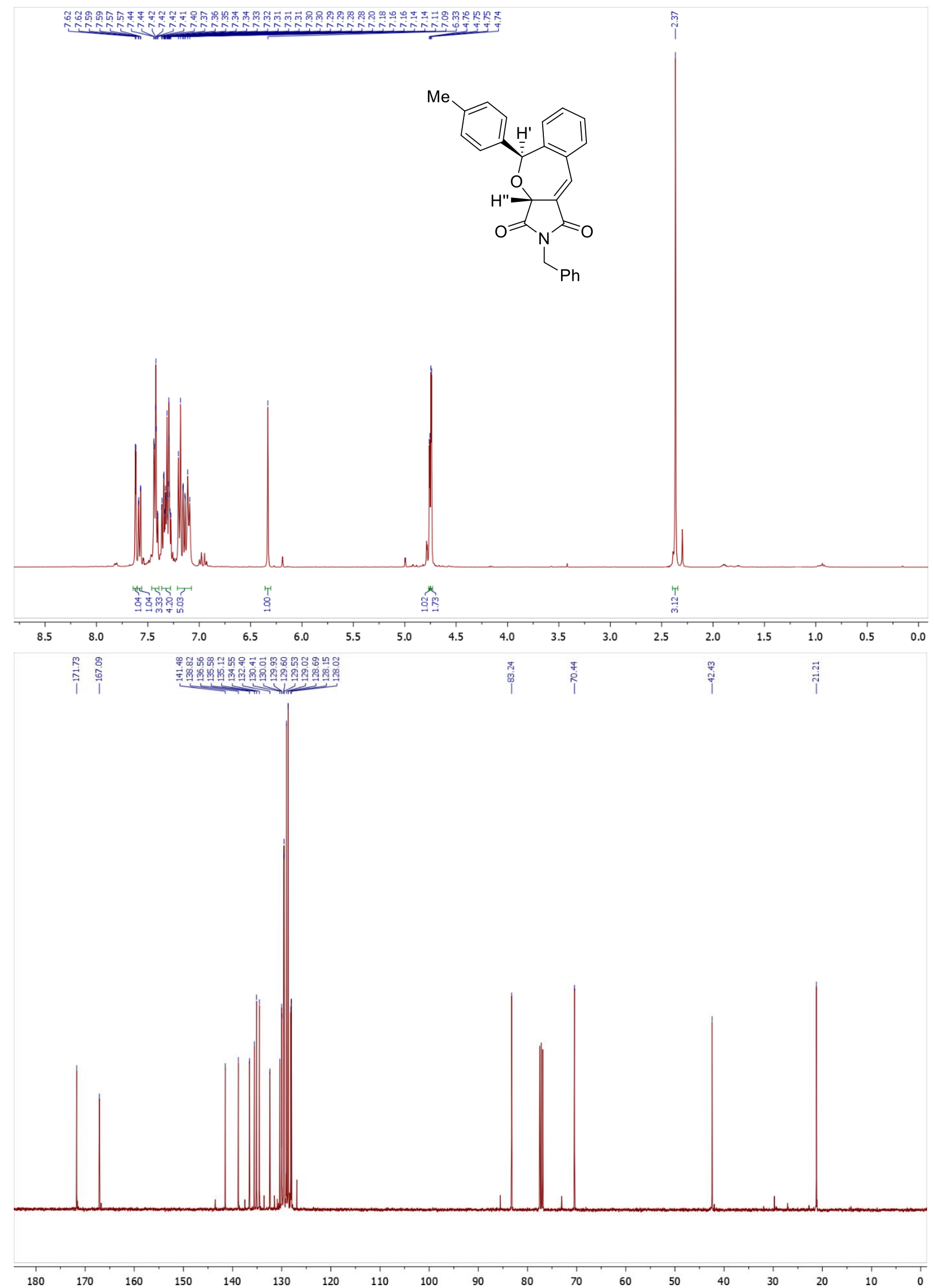
Copy of NOESY spectrum of $\mathbf{2 b}$

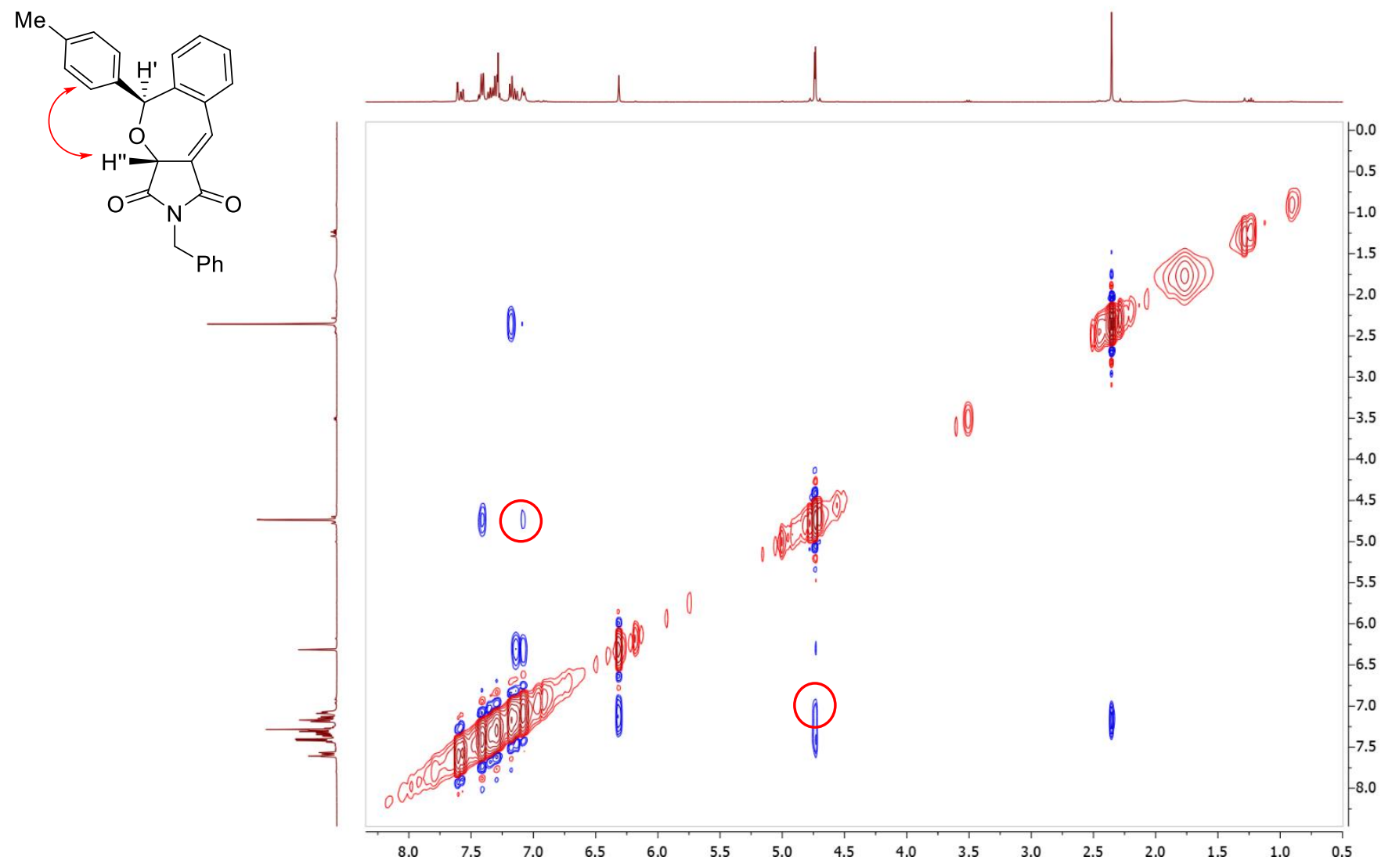


Copies of ${ }^{1} \mathrm{H}\left(400.13 \mathrm{MHz}, \mathrm{CDCl}_{3}\right)$ and ${ }^{13} \mathrm{C}\left\{{ }^{1} \mathrm{H}\right\}\left(100.61 \mathrm{MHz}, \mathrm{CDCl}_{3}\right)$ spectra of $\mathbf{2 c}$

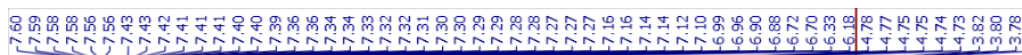
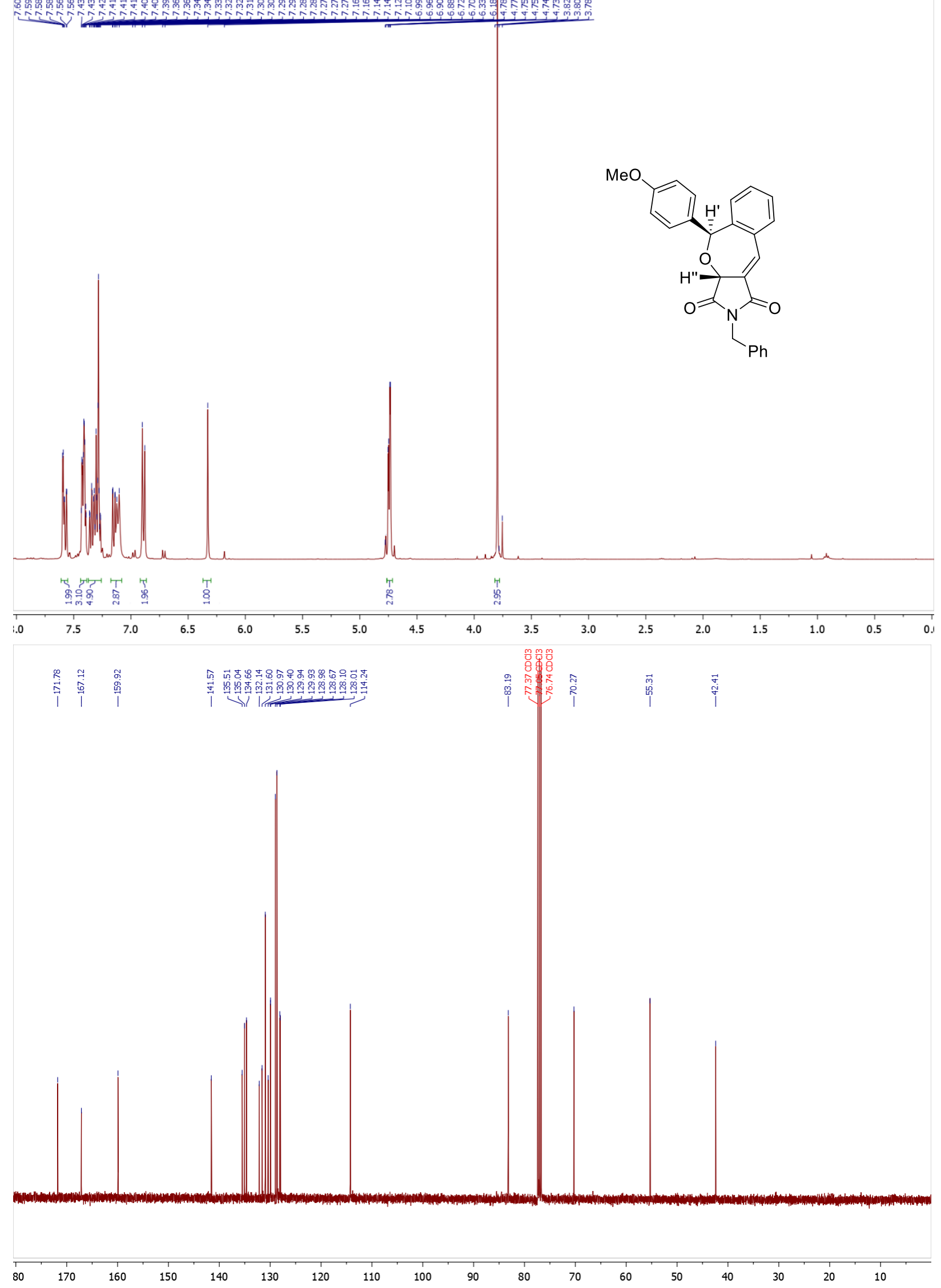


\section{Copy of NOESY spectrum of $\mathbf{2 c}$}

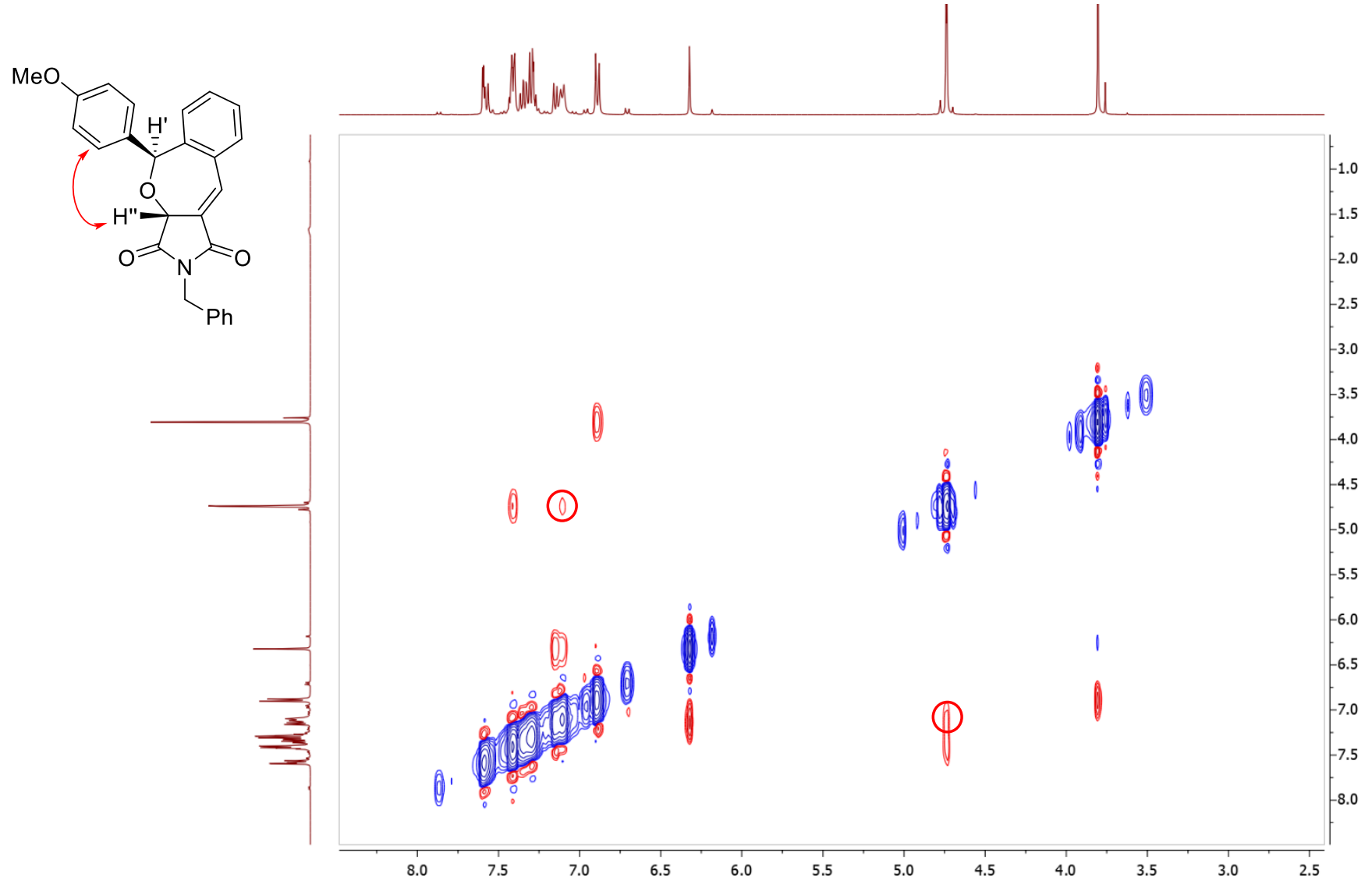


Copies of ${ }^{1} \mathrm{H}\left(400.13 \mathrm{MHz}, \mathrm{CDCl}_{3}\right)$ and ${ }^{13} \mathrm{C}\left\{{ }^{1} \mathrm{H}\right\}\left(100.61 \mathrm{MHz}, \mathrm{CDCl}_{3}\right)$ spectra of $\mathbf{3 d}$

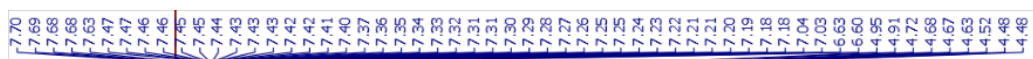
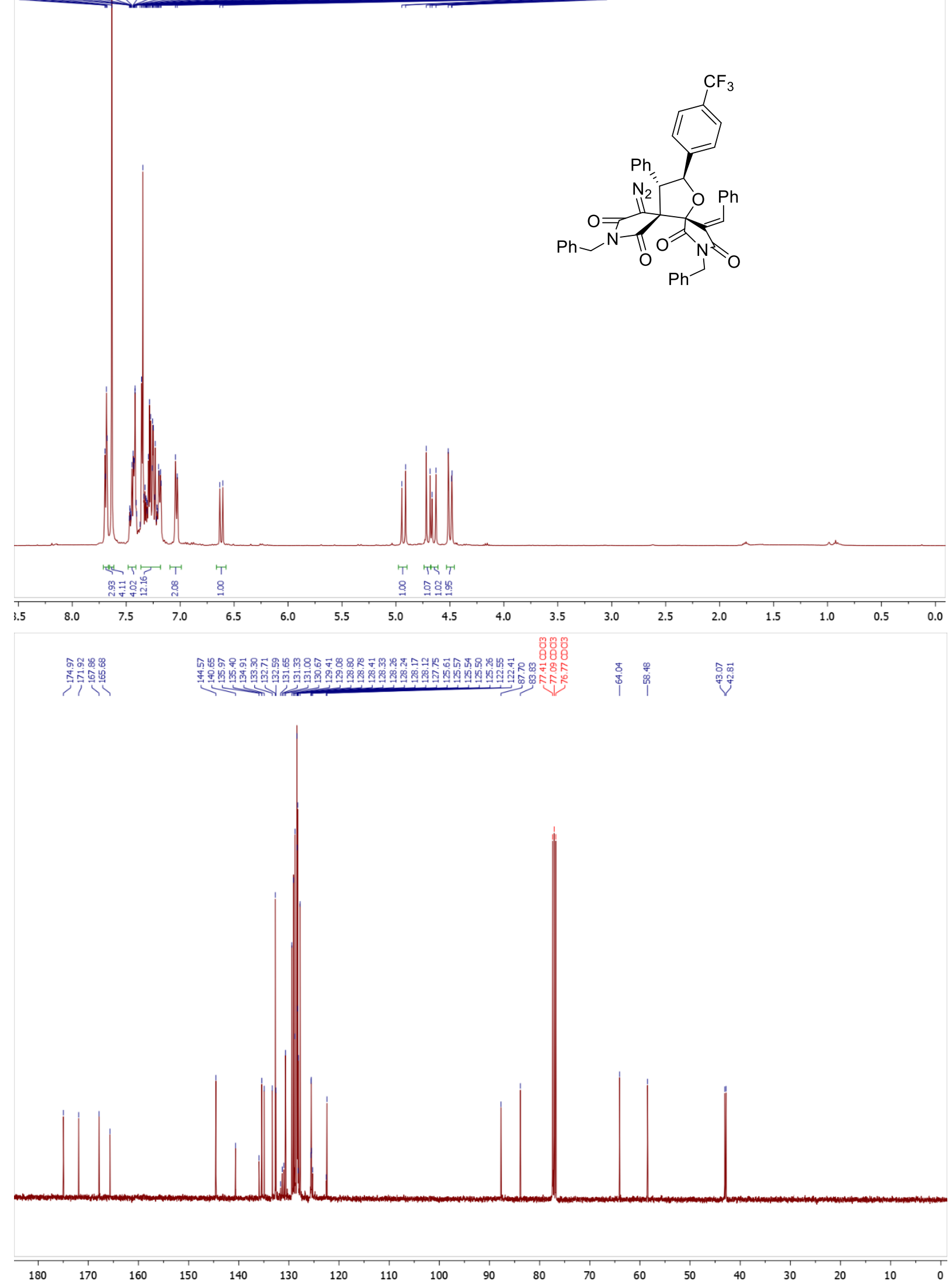
Copy of ${ }^{19} \mathrm{~F}\left\{{ }^{1} \mathrm{H}\right\}\left(376.50 \mathrm{MHz}, \mathrm{CDCl}_{3}\right)$ spectrum of $\mathbf{3 d}$

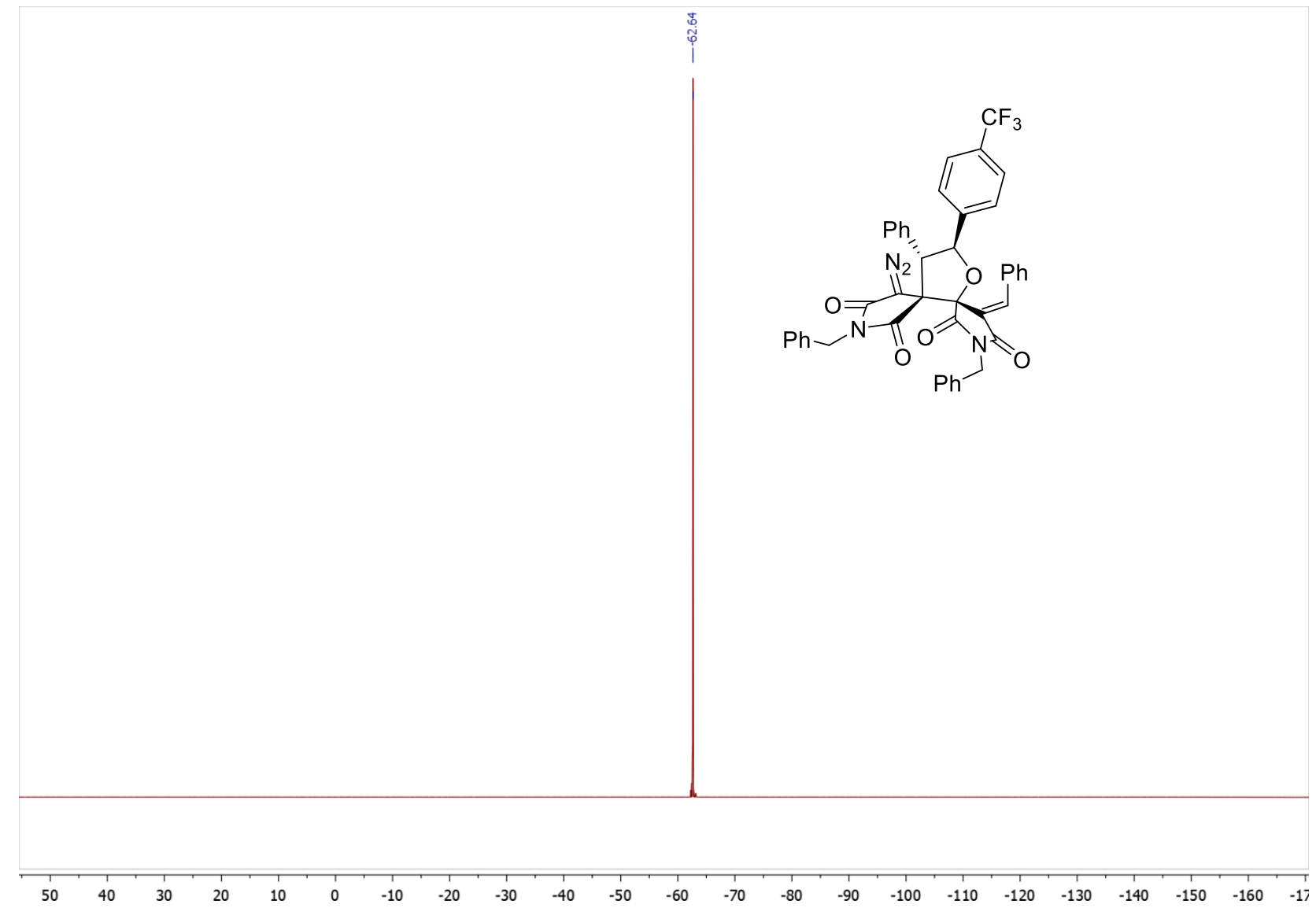


Copies of ${ }^{1} \mathrm{H}\left(400.13 \mathrm{MHz}, \mathrm{CDCl}_{3}\right)$ and ${ }^{13} \mathrm{C}\left\{{ }^{1} \mathrm{H}\right\}\left(100.61 \mathrm{MHz}, \mathrm{CDCl}_{3}\right)$ spectra of $\mathbf{3 e}$

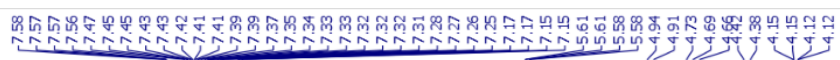
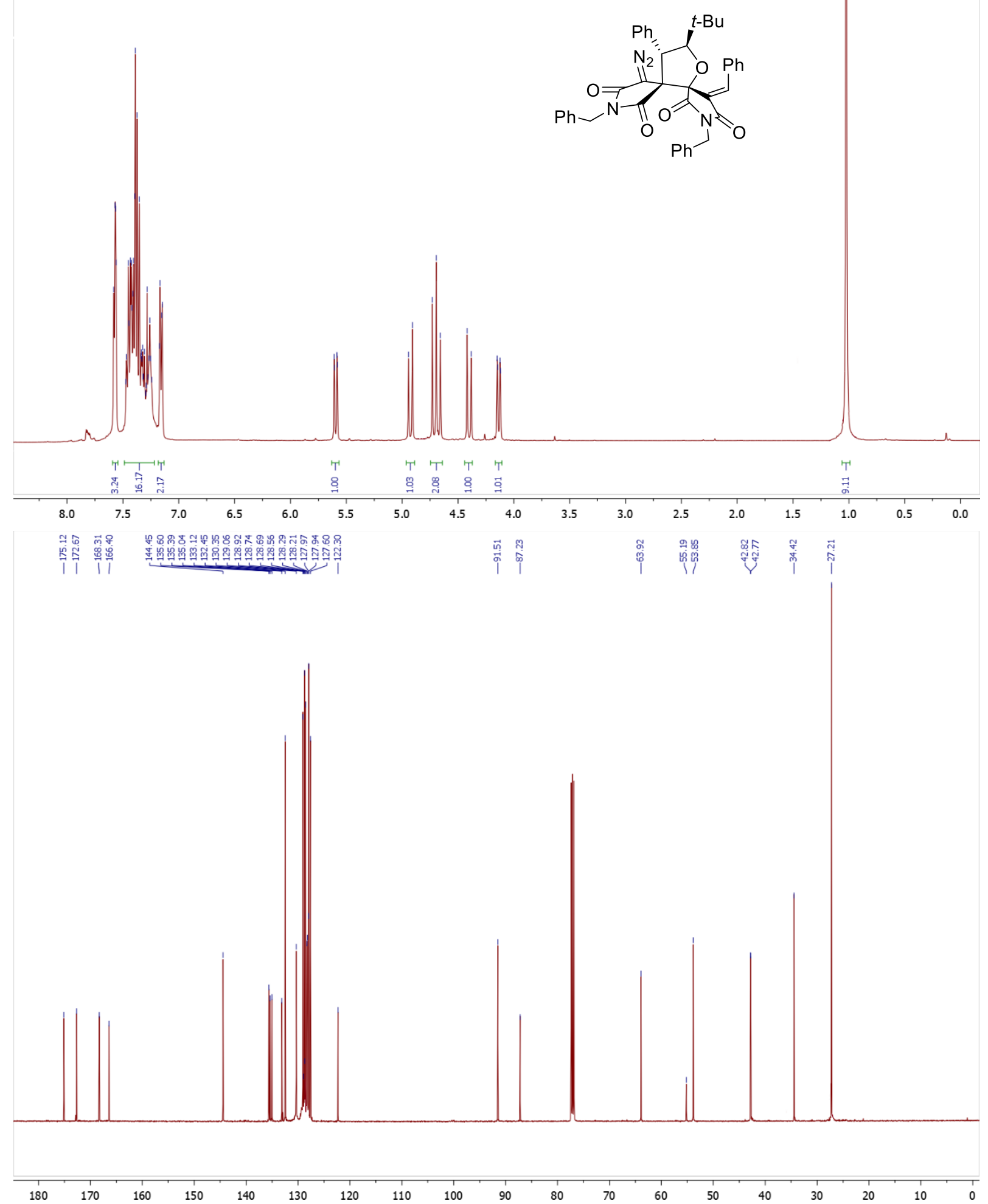
Copy of NOESY spectrum of $\mathbf{3 e}$

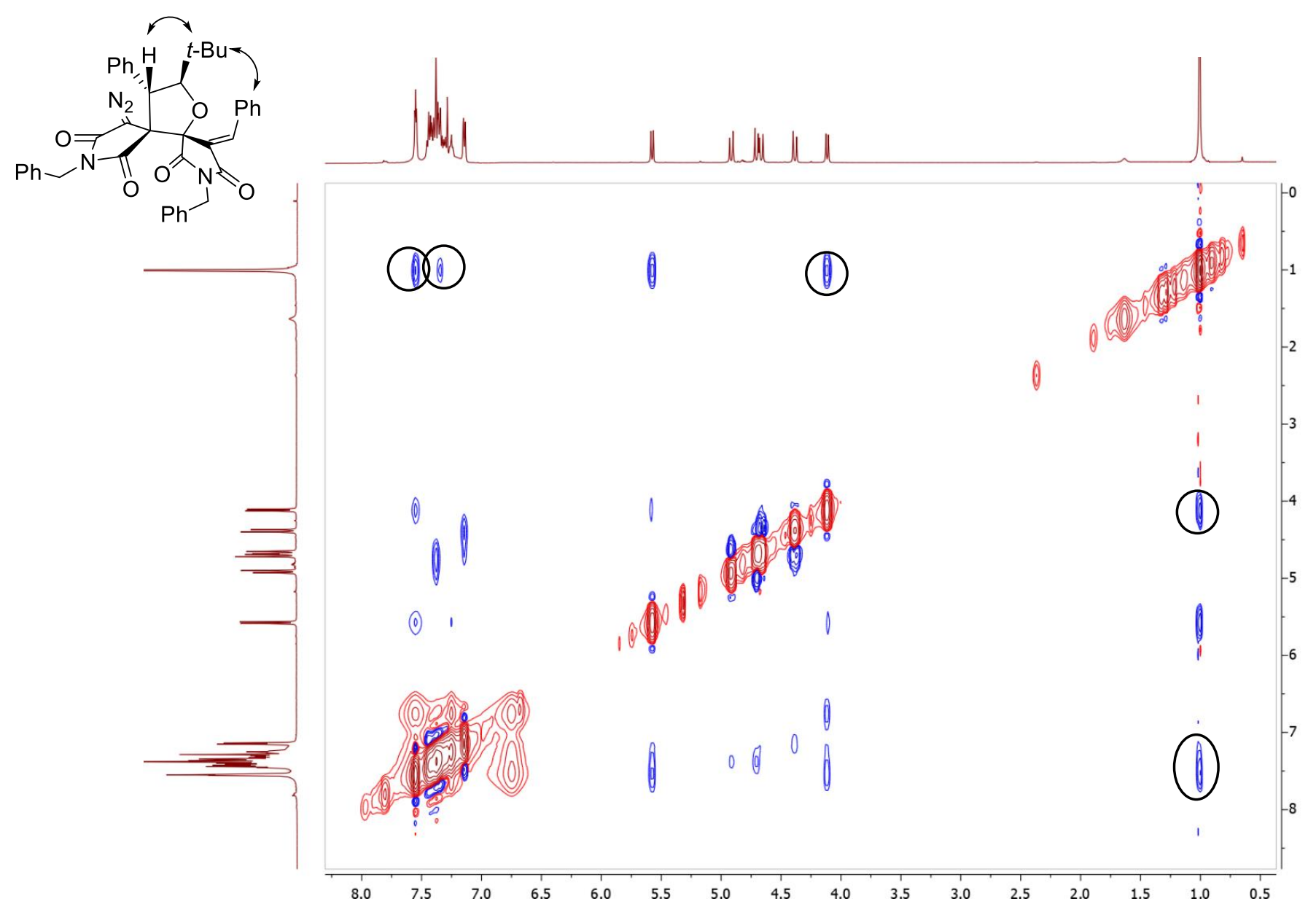


Copies of ${ }^{1} \mathrm{H}\left(400.13 \mathrm{MHz}, \mathrm{CDCl}_{3}\right)$ and ${ }^{13} \mathrm{C}\left\{{ }^{1} \mathrm{H}\right\}\left(100.61 \mathrm{MHz}, \mathrm{CDCl}_{3}\right)$ spectra of $2 \mathbf{f}$

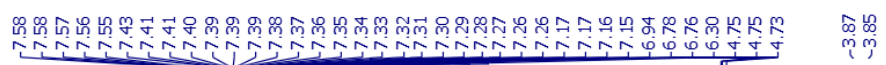
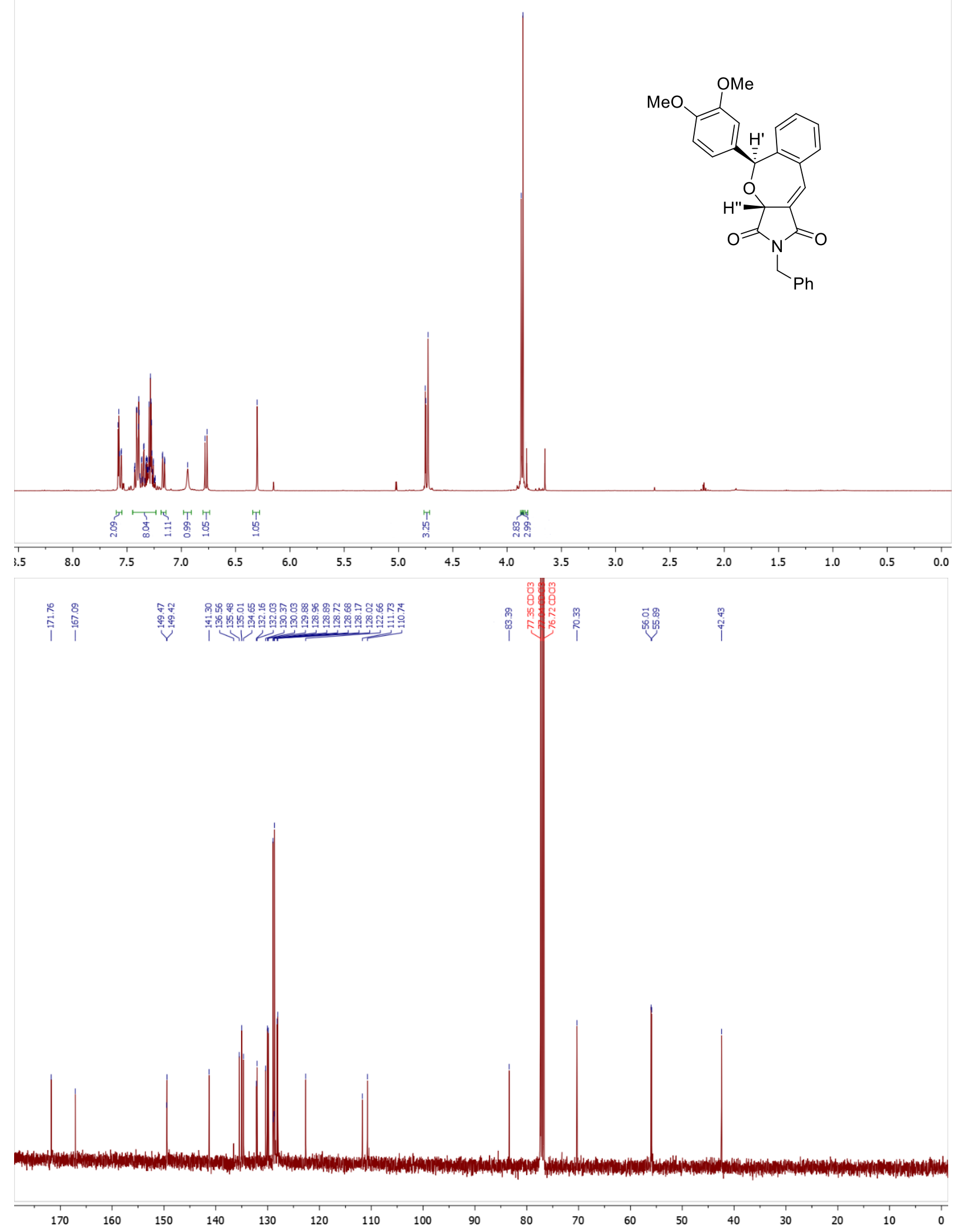
Copies of ${ }^{1} \mathrm{H}\left(400.13 \mathrm{MHz}, \mathrm{CDCl}_{3}\right)$ and ${ }^{13} \mathrm{C}\left\{{ }^{1} \mathrm{H}\right\}\left(100.61 \mathrm{MHz}, \mathrm{CDCl}_{3}\right)$ spectra of $2 \mathrm{~g}$

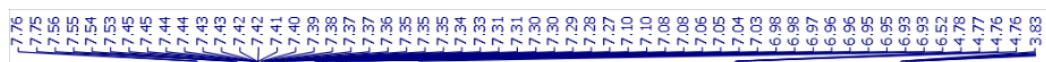

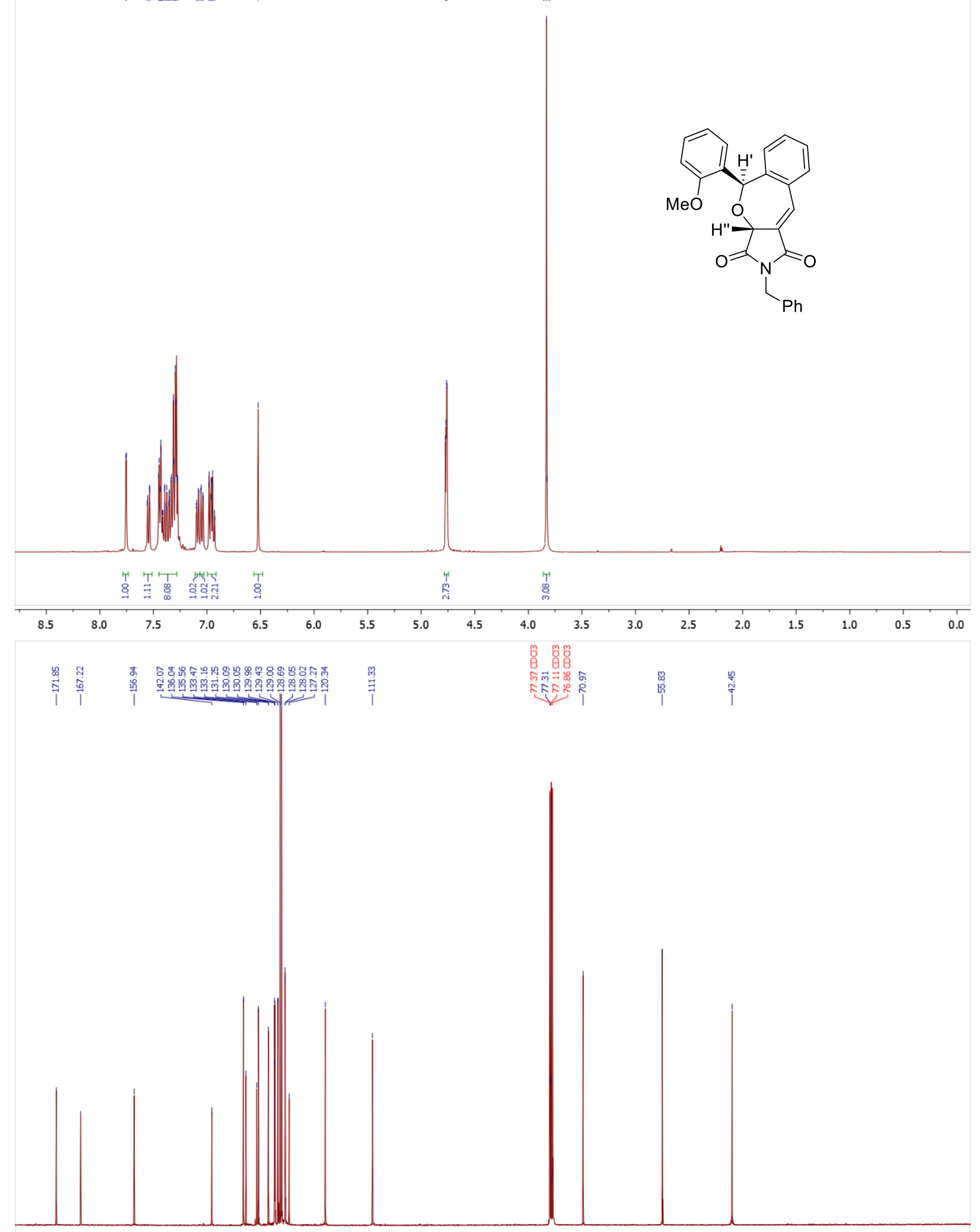

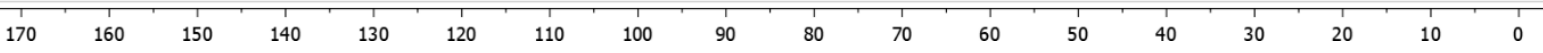


Copies of ${ }^{1} \mathrm{H}\left(400.13 \mathrm{MHz}, \mathrm{CDCl}_{3}\right)$ and ${ }^{13} \mathrm{C}\left\{{ }^{1} \mathrm{H}\right\}\left(100.61 \mathrm{MHz}, \mathrm{CDCl}_{3}\right)$ spectra of $\mathbf{2 h}$

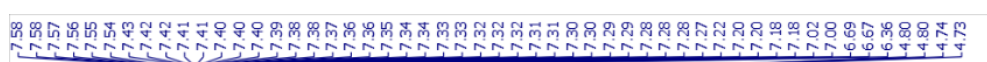

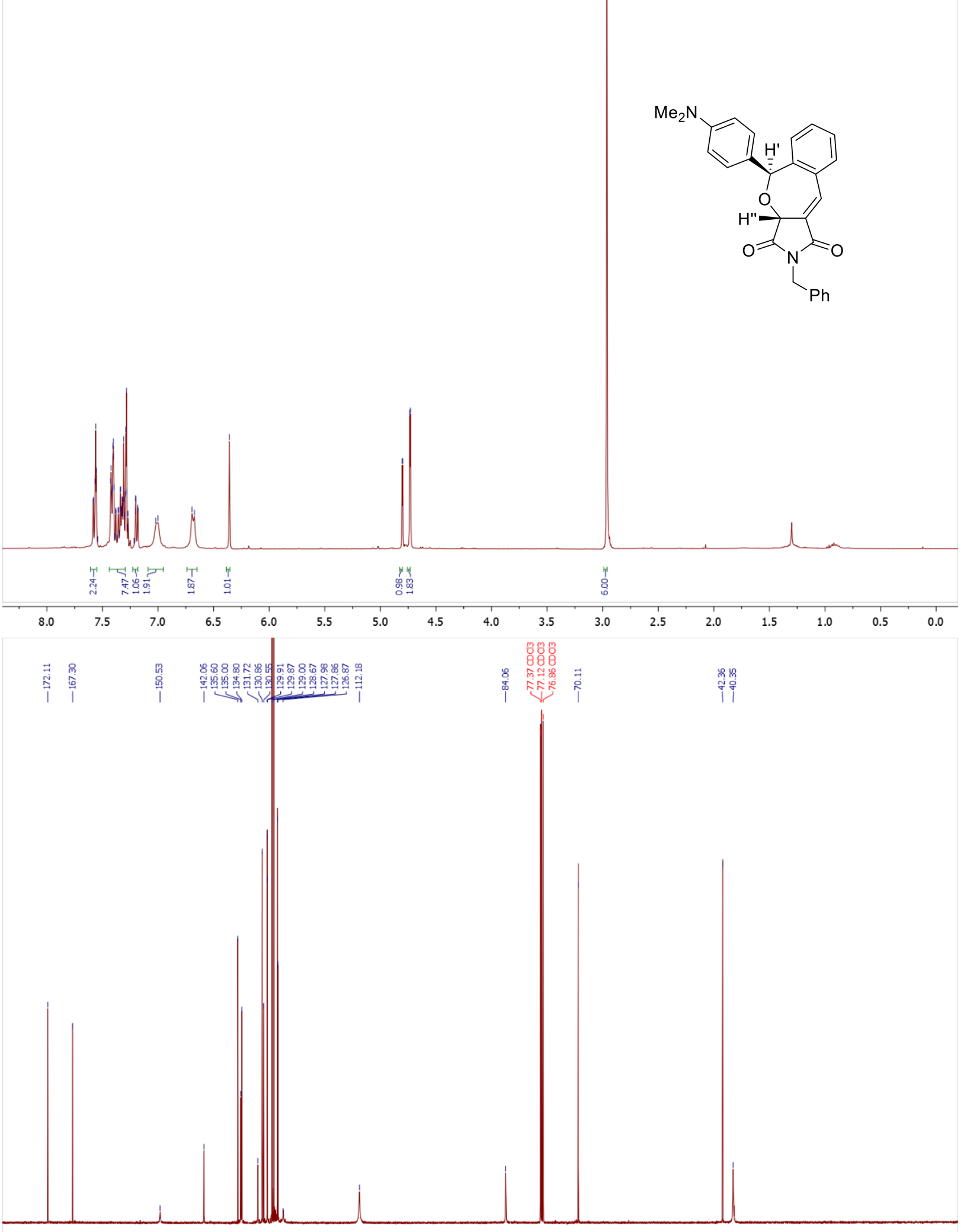


Copies of ${ }^{1} \mathrm{H}\left(400.13 \mathrm{MHz}, \mathrm{CDCl}_{3}\right)$ and ${ }^{13} \mathrm{C}\left\{{ }^{1} \mathrm{H}\right\}\left(100.61 \mathrm{MHz}, \mathrm{CDCl}_{3}\right)$ spectra of $2 \mathbf{i}$

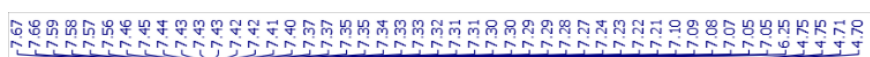

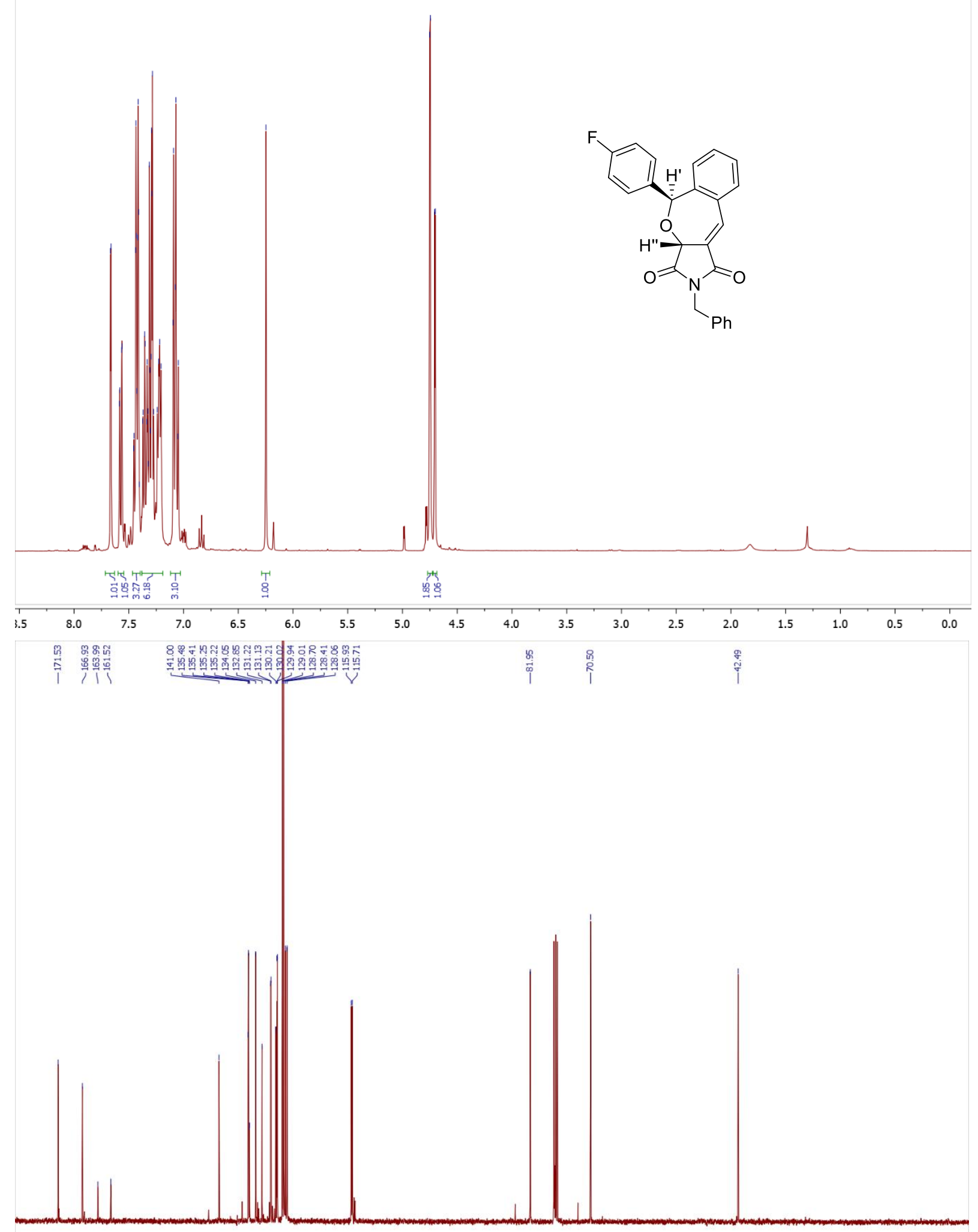

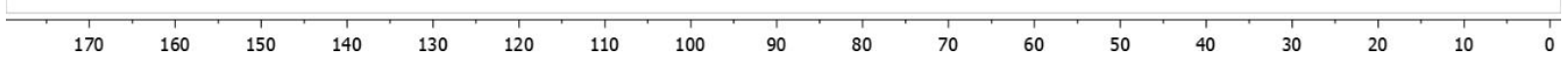


Copy of ${ }^{19} \mathrm{~F}\left\{{ }^{1} \mathrm{H}\right\}\left(376.50 \mathrm{MHz}, \mathrm{CDCl}_{3}\right)$ spectrum and NOESY spectrum of $\mathbf{2 i}$

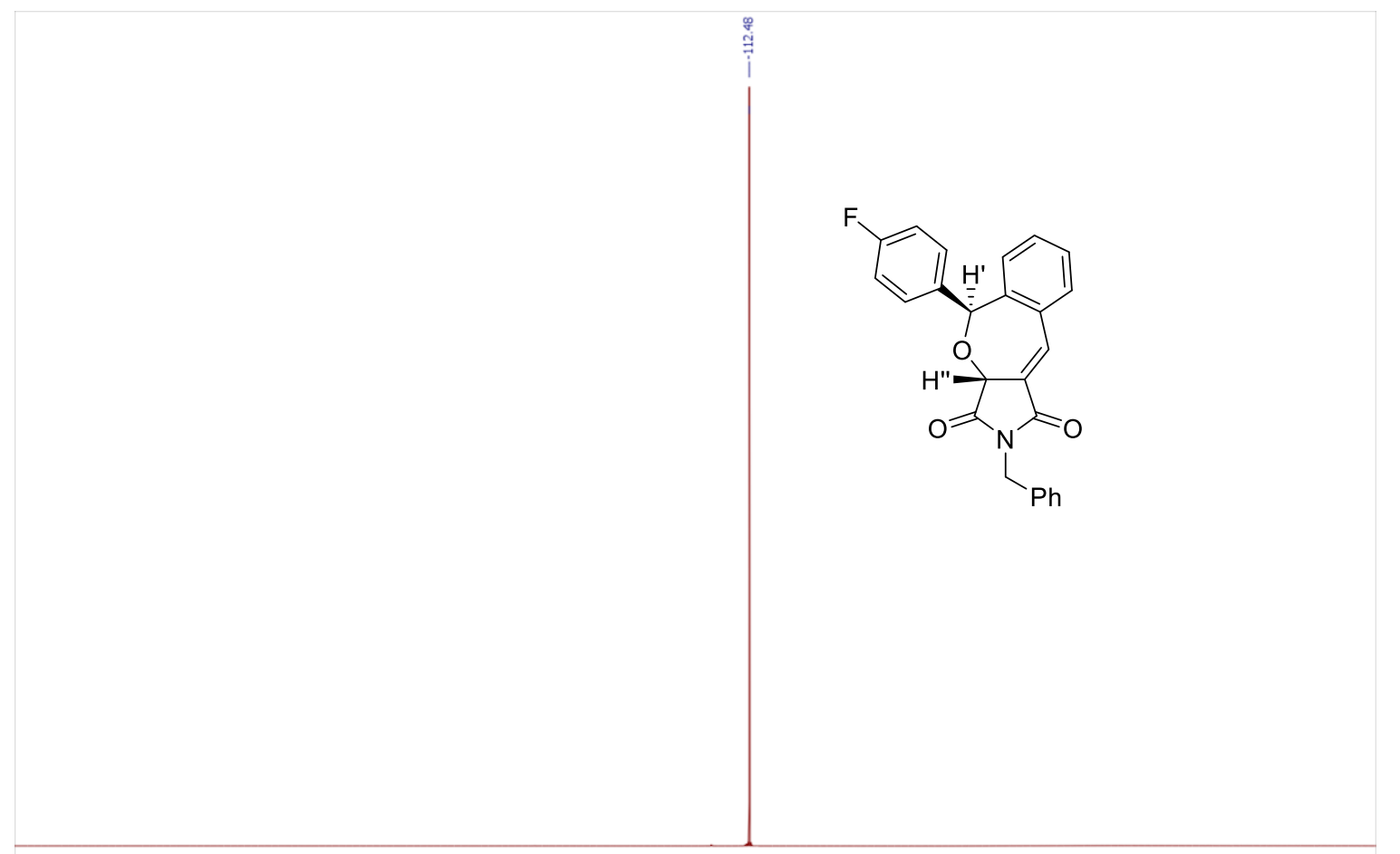

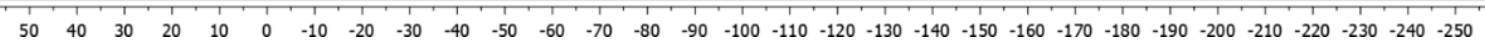

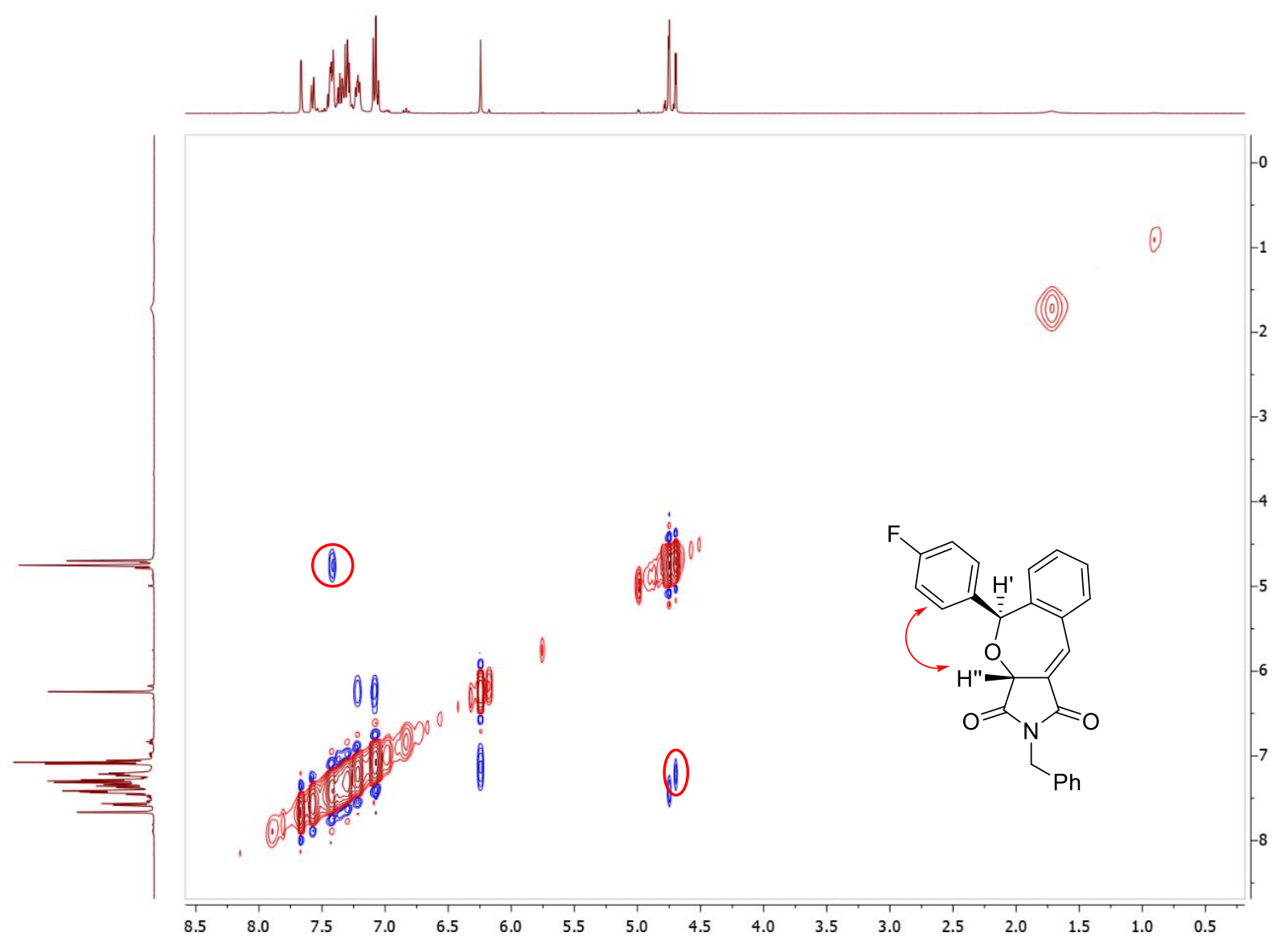


Copies of ${ }^{1} \mathrm{H}\left(400.13 \mathrm{MHz}, \mathrm{CDCl}_{3}\right)$ and ${ }^{13} \mathrm{C}\left\{{ }^{1} \mathrm{H}\right\}\left(100.61 \mathrm{MHz}, \mathrm{CDCl}_{3}\right)$ spectra of $\mathbf{2} \mathbf{j}$
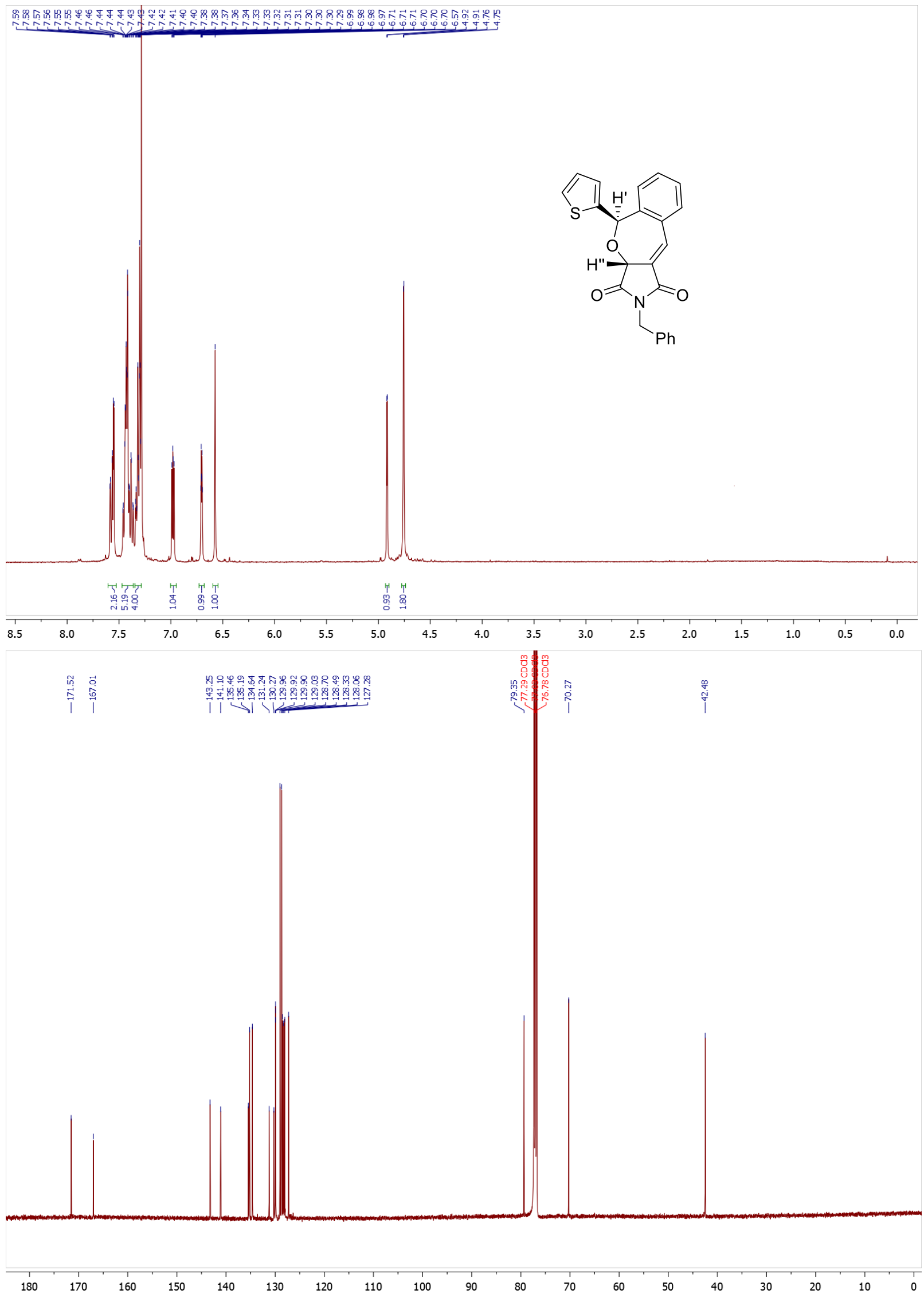
Copies of ${ }^{1} \mathrm{H}\left(400.13 \mathrm{MHz}, \mathrm{CDCl}_{3}\right)$ and ${ }^{13} \mathrm{C}\left\{{ }^{1} \mathrm{H}\right\}\left(100.61 \mathrm{MHz}, \mathrm{CDCl}_{3}\right)$ spectra of $2 \mathbf{k}$
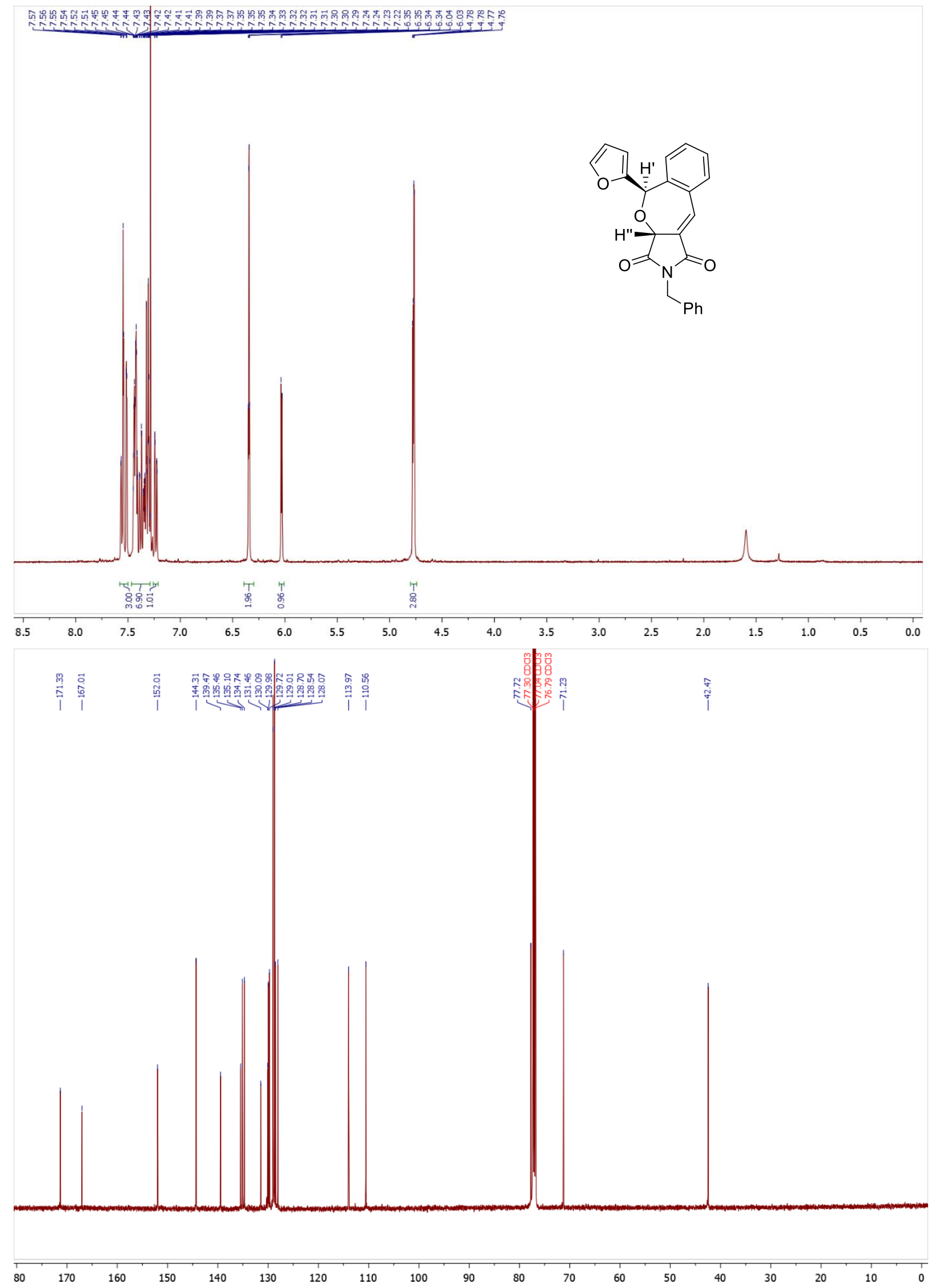
Copy of NOESY spectrum of $\mathbf{2} \mathbf{k}$

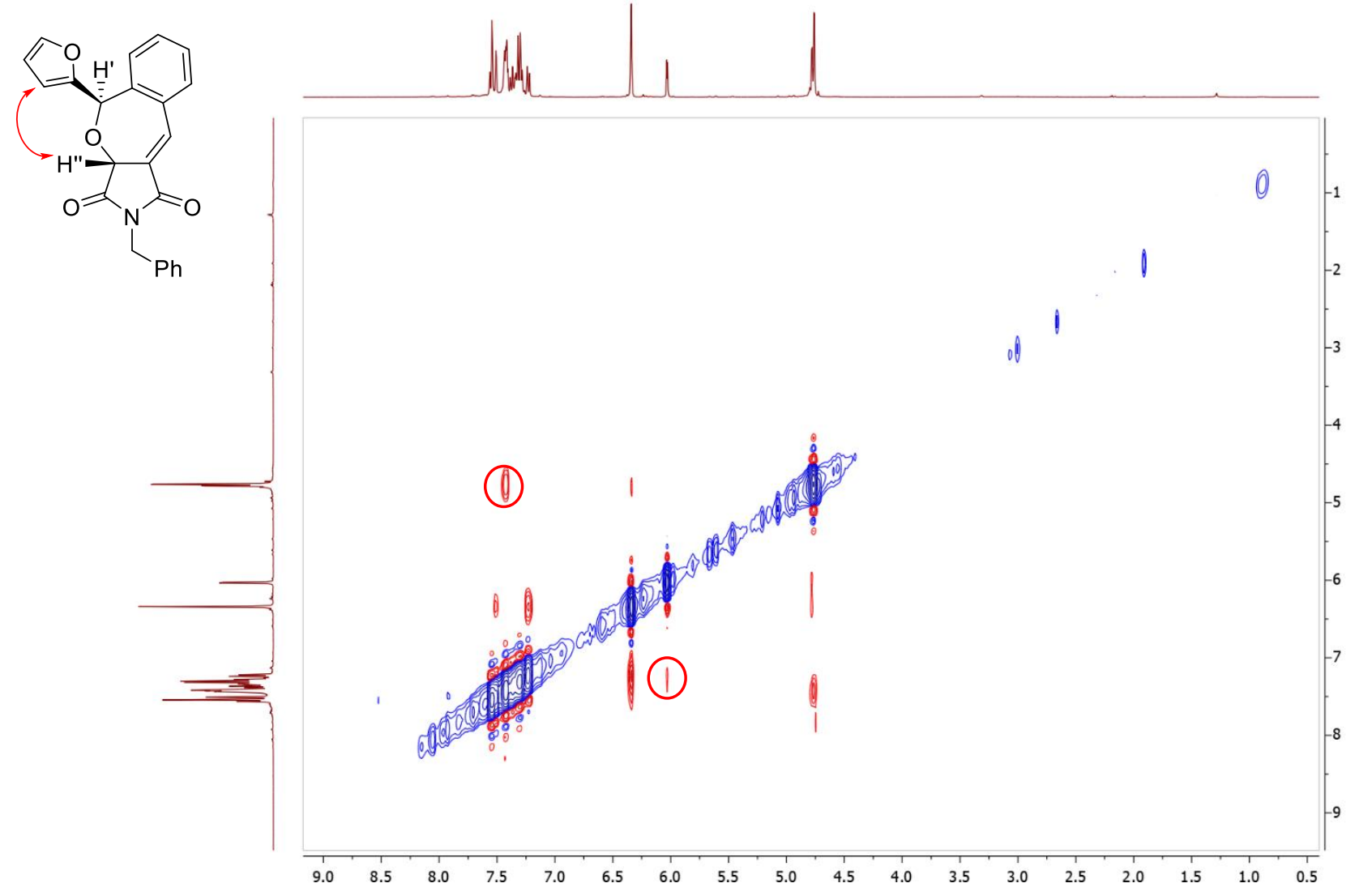


Copies of ${ }^{1} \mathrm{H}\left(400.13 \mathrm{MHz}, \mathrm{CDCl}_{3}\right)$ and ${ }^{13} \mathrm{C}\left\{{ }^{1} \mathrm{H}\right\}\left(100.61 \mathrm{MHz}, \mathrm{CDCl}_{3}\right)$ spectra of $2 \mathbf{l}$

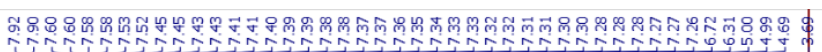
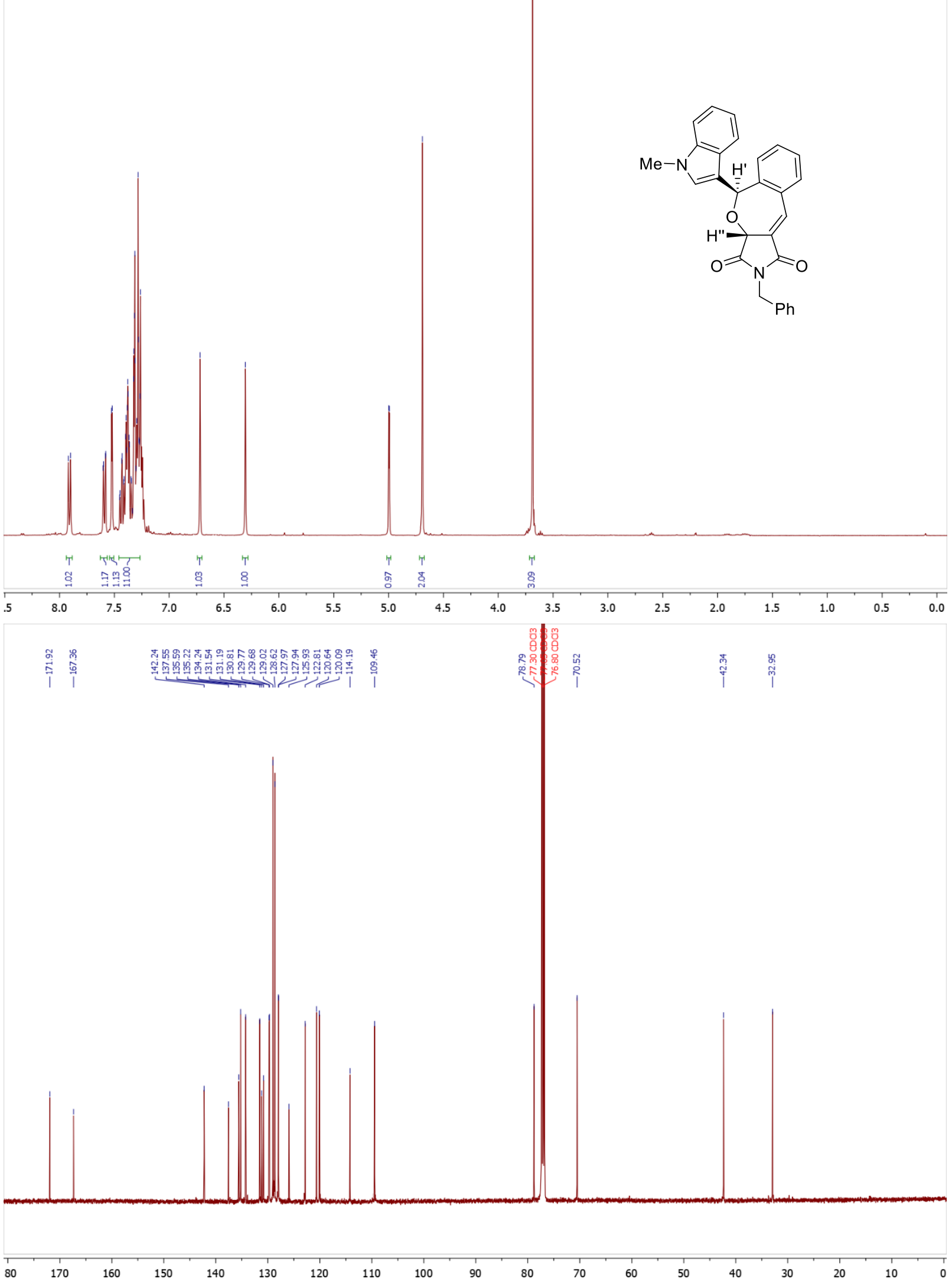
Copy of NOESY spectrum of $\mathbf{2 l}$

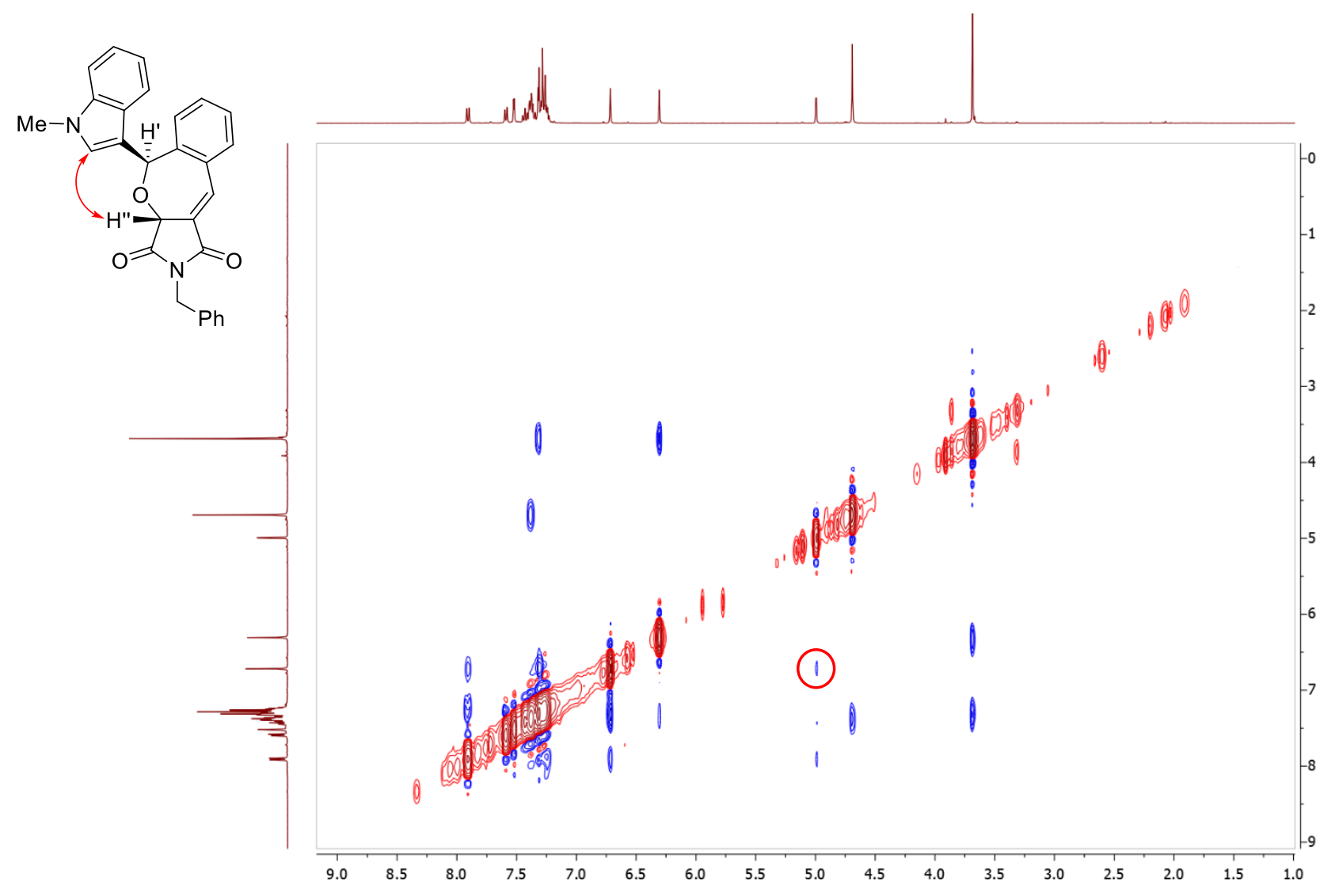


Copies of ${ }^{1} \mathrm{H}\left(400.13 \mathrm{MHz}, \mathrm{CDCl}_{3}\right)$ and ${ }^{13} \mathrm{C}\left\{{ }^{1} \mathrm{H}\right\}\left(100.61 \mathrm{MHz}, \mathrm{CDCl}_{3}\right)$ spectra of $\mathbf{2 m}$

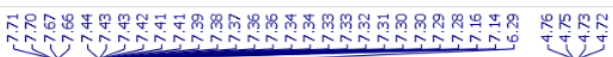
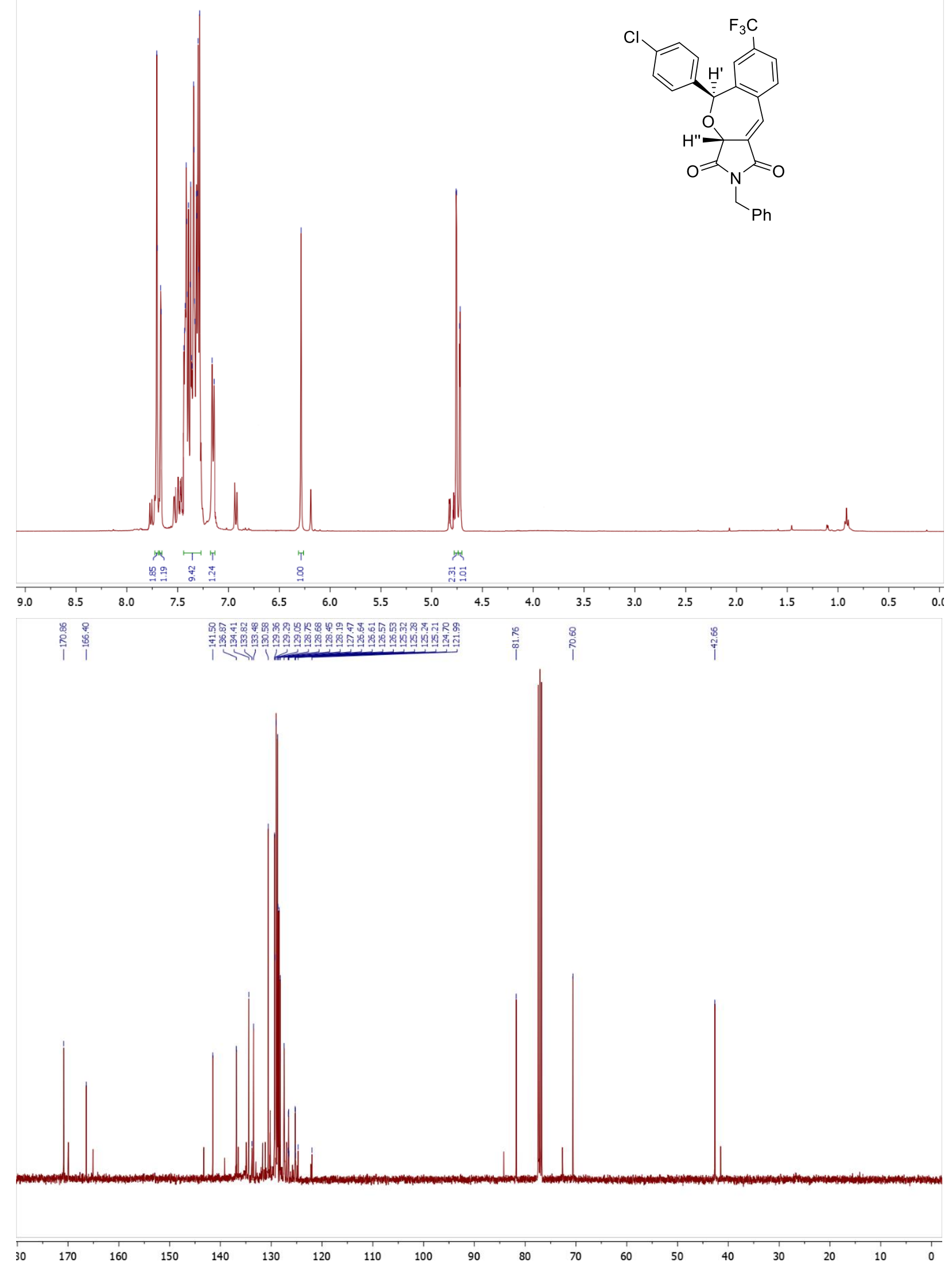
Copy of ${ }^{19} \mathrm{~F}\left\{{ }^{1} \mathrm{H}\right\}\left(376.50 \mathrm{MHz}, \mathrm{CDCl}_{3}\right)$ spectrum and NOESY spectrum of $\mathbf{2} \mathbf{m}$
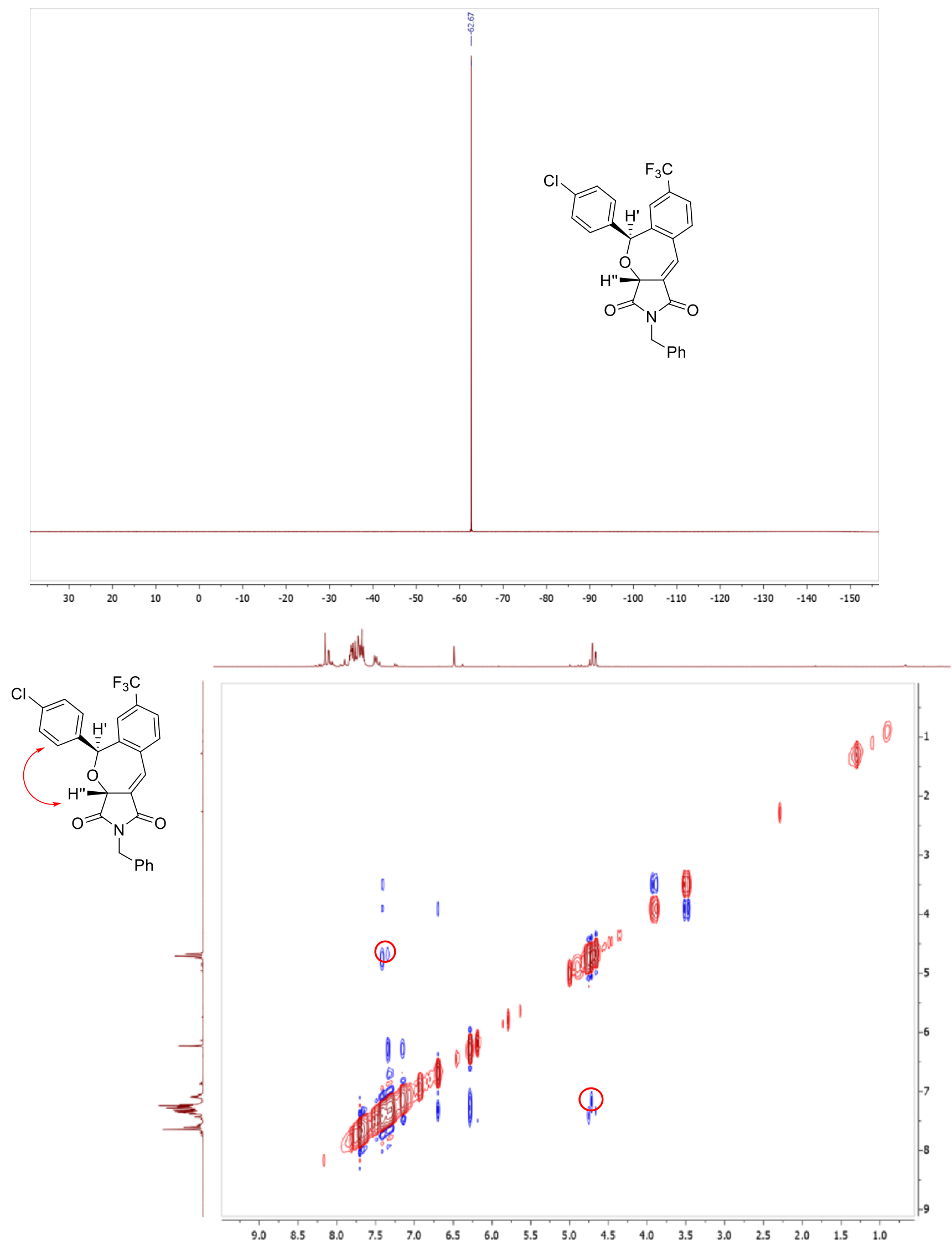
Copies of ${ }^{1} \mathrm{H}\left(400.13 \mathrm{MHz}, \mathrm{CDCl}_{3}\right)$ and ${ }^{13} \mathrm{C}\left\{{ }^{1} \mathrm{H}\right\}\left(100.61 \mathrm{MHz}, \mathrm{CDCl}_{3}\right)$ spectra of $\mathbf{3 m}$
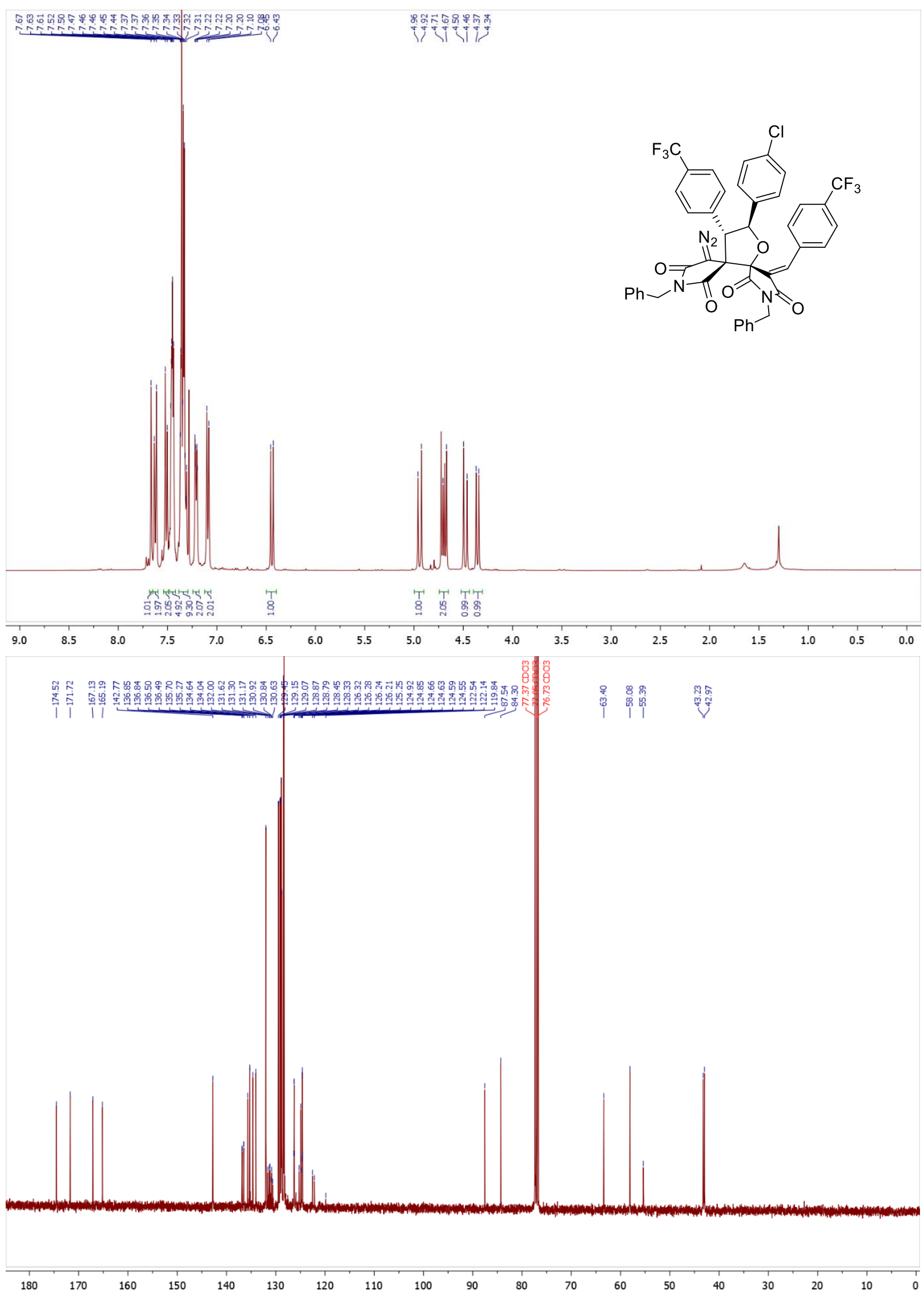
Copy of ${ }^{19} \mathrm{~F}\left\{{ }^{1} \mathrm{H}\right\}\left(376.50 \mathrm{MHz}, \mathrm{CDCl}_{3}\right)$ spectrum of $\mathbf{3 m}$

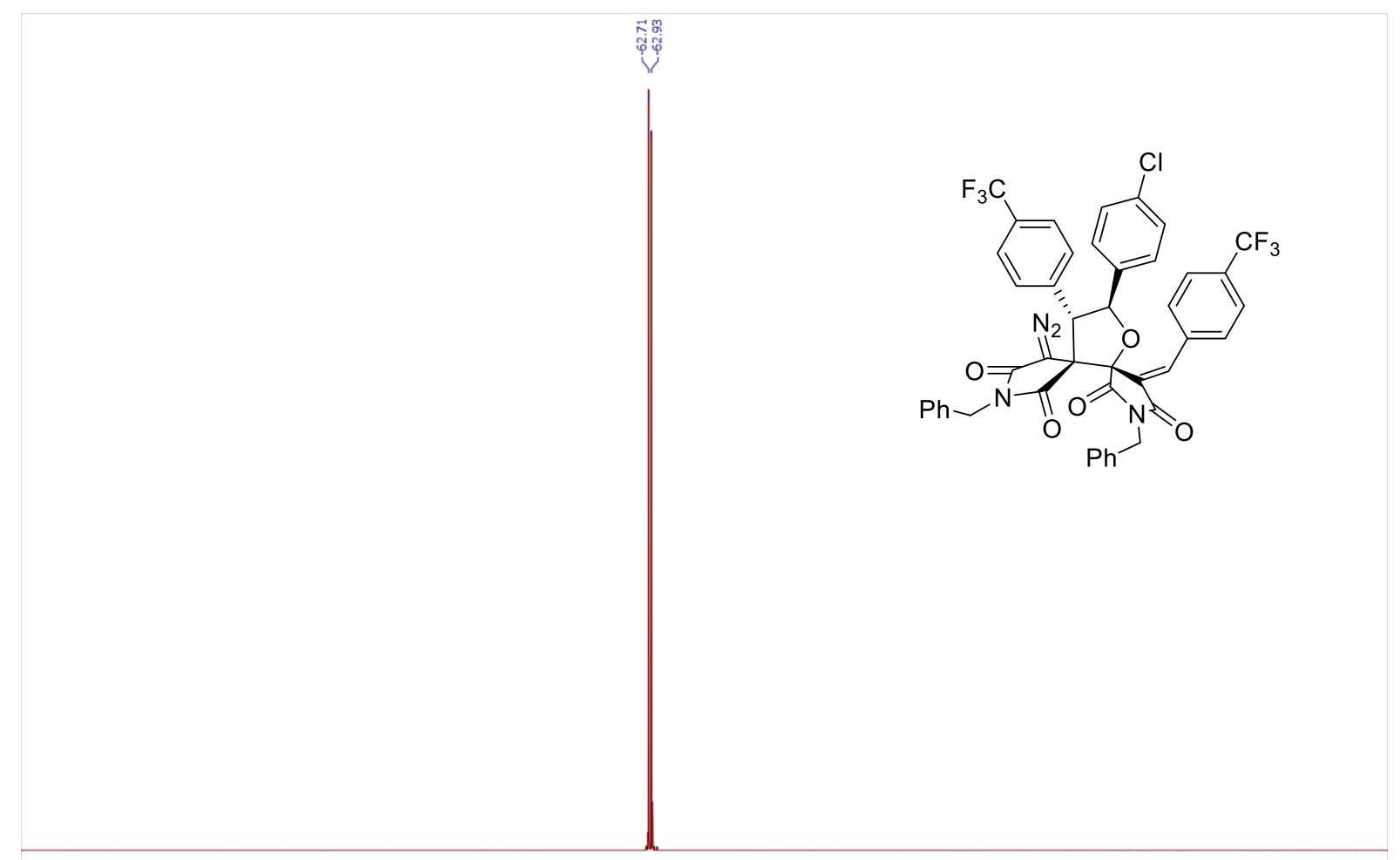

\begin{tabular}{lllllllllllllllllllllllllllllll}
\hline 10 & -15 & -20 & -25 & -30 & -35 & -40 & -45 & -50 & -55 & -60 & -65 & -70 & -75 & -80 & -85 & -90 & -95 & -100 & -105 & -110 & -115 & -120 & -1
\end{tabular}


Copies of ${ }^{1} \mathrm{H}\left(400.13 \mathrm{MHz}, \mathrm{CDCl}_{3}\right)$ and ${ }^{13} \mathrm{C}\left\{{ }^{1} \mathrm{H}\right\}\left(100.61 \mathrm{MHz}, \mathrm{CDCl}_{3}\right)$ spectra of $2 \mathbf{n}$
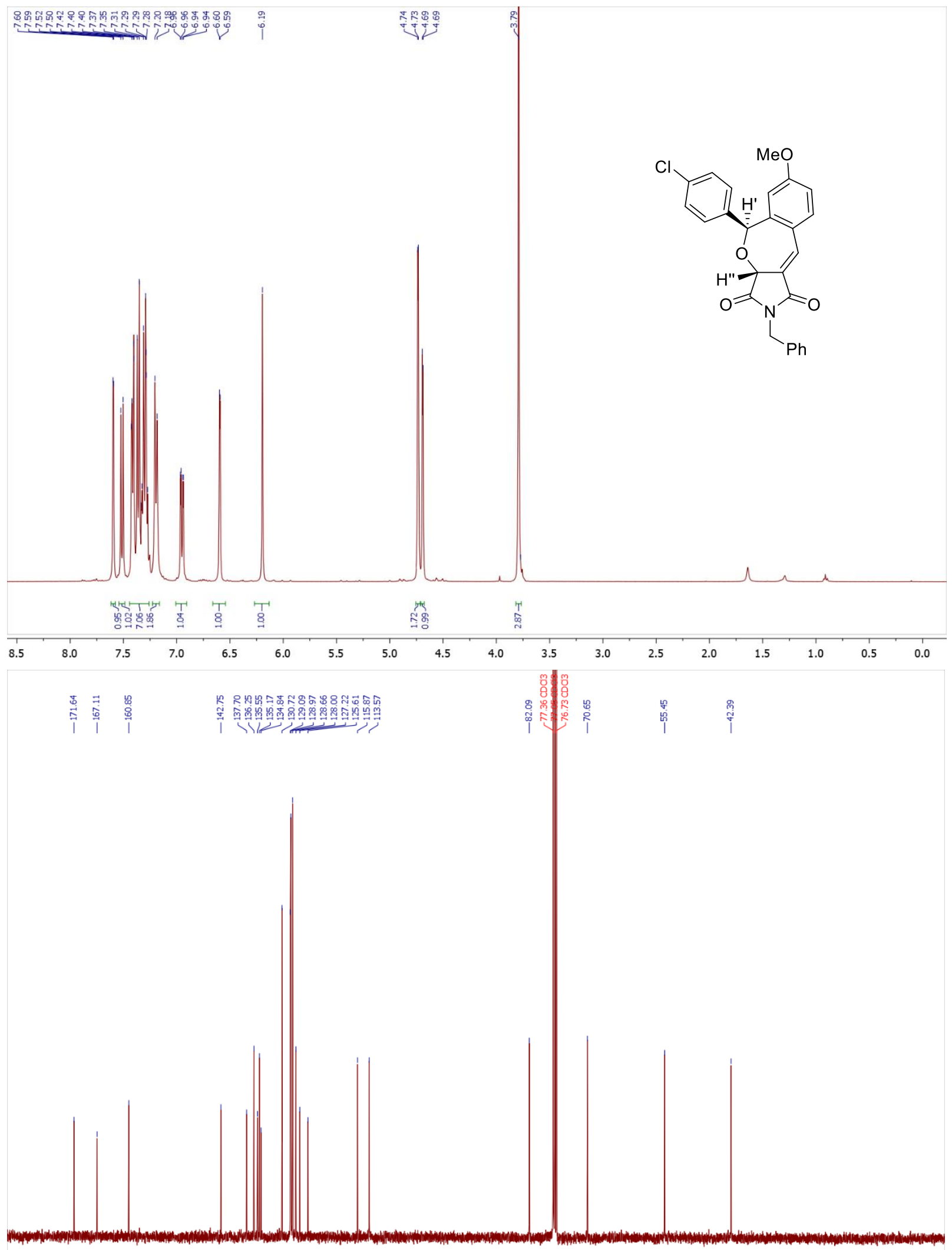

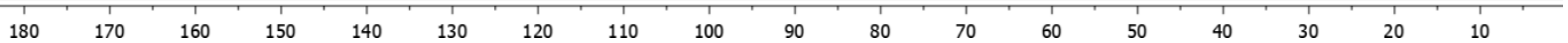


Copies of ${ }^{1} \mathrm{H}\left(400.13 \mathrm{MHz}, \mathrm{CDCl}_{3}\right)$ and ${ }^{13} \mathrm{C}\left\{{ }^{1} \mathrm{H}\right\}\left(100.61 \mathrm{MHz}, \mathrm{CDCl}_{3}\right)$ spectra of $3 \mathbf{n}$
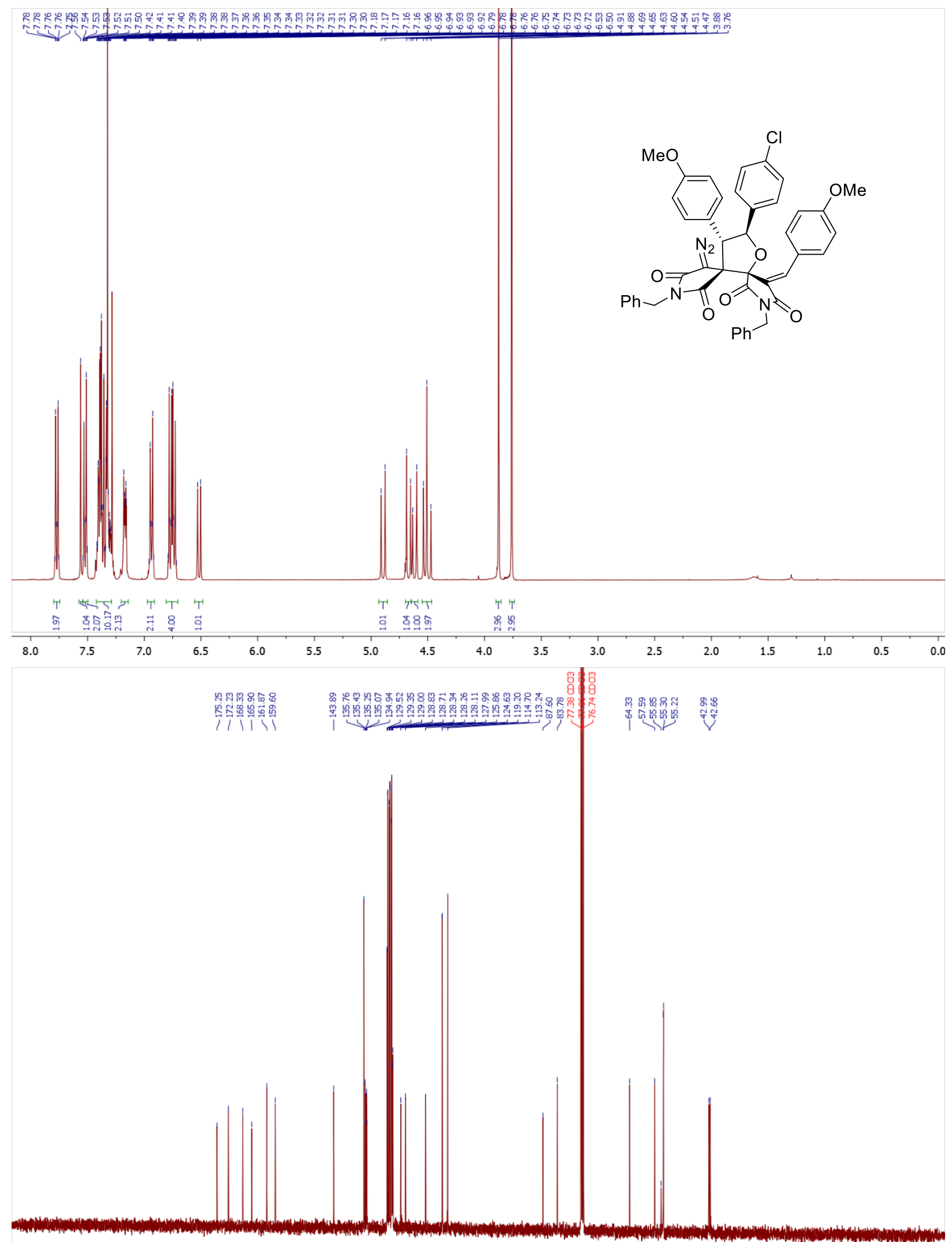

\begin{tabular}{llllllllllllllllllllllllllllll}
\hline 30 & 220 & 210 & 200 & 190 & 180 & 170 & 160 & 150 & 140 & 130 & 120 & 110 & 100 & 90 & 80 & 70 & 60 & 50 & 40 & 30 & 20 & 10 & 0 & -10 & -2
\end{tabular} 
Copies of ${ }^{1} \mathrm{H}\left(400.13 \mathrm{MHz}, \mathrm{CDCl}_{3}\right)$ and ${ }^{13} \mathrm{C}\left\{{ }^{1} \mathrm{H}\right\}\left(100.61 \mathrm{MHz}, \mathrm{CDCl}_{3}\right)$ spectra of $2 \mathrm{o}$

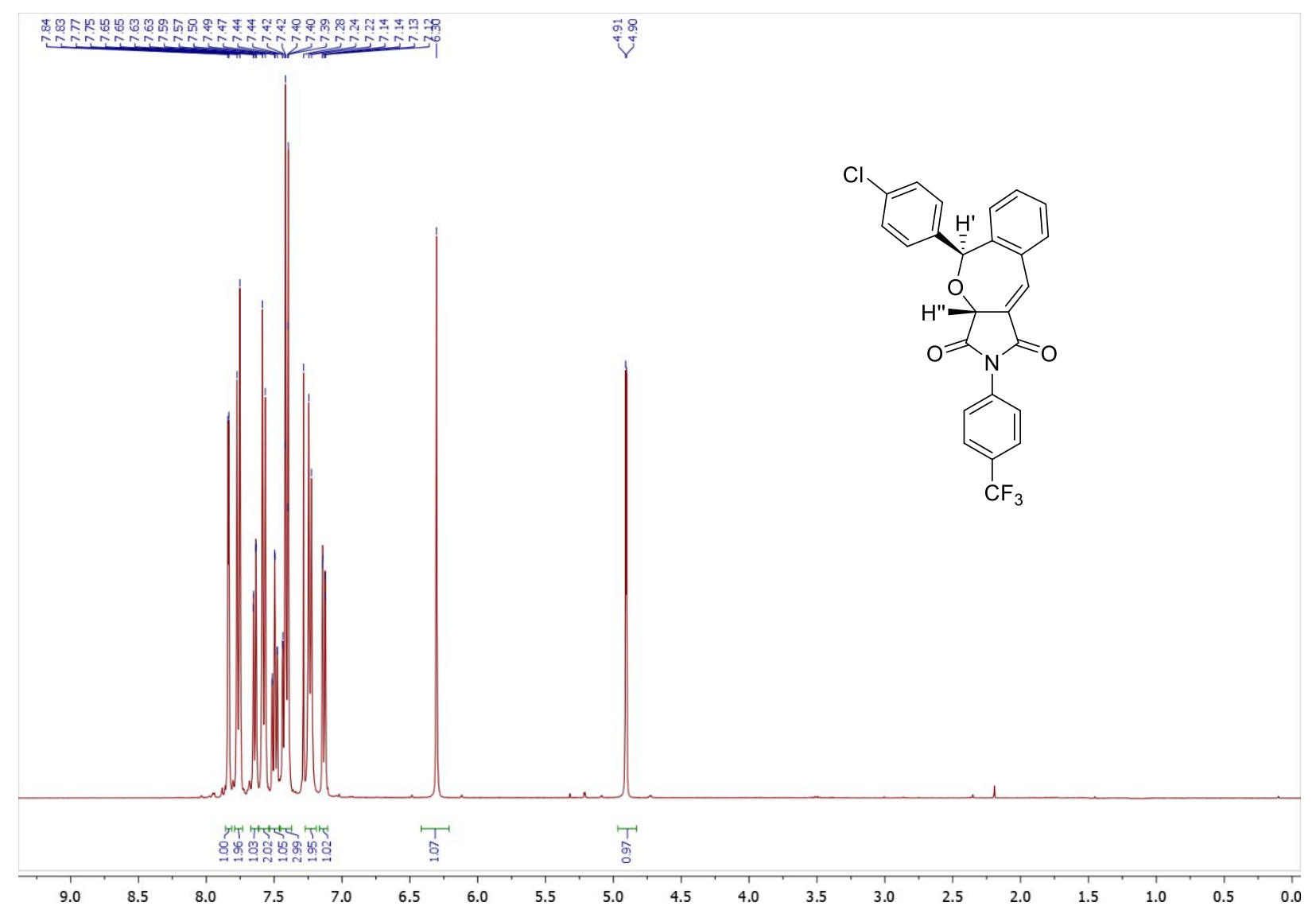

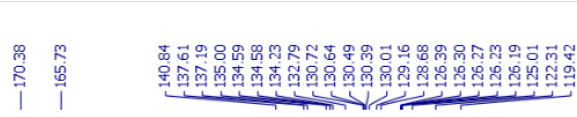
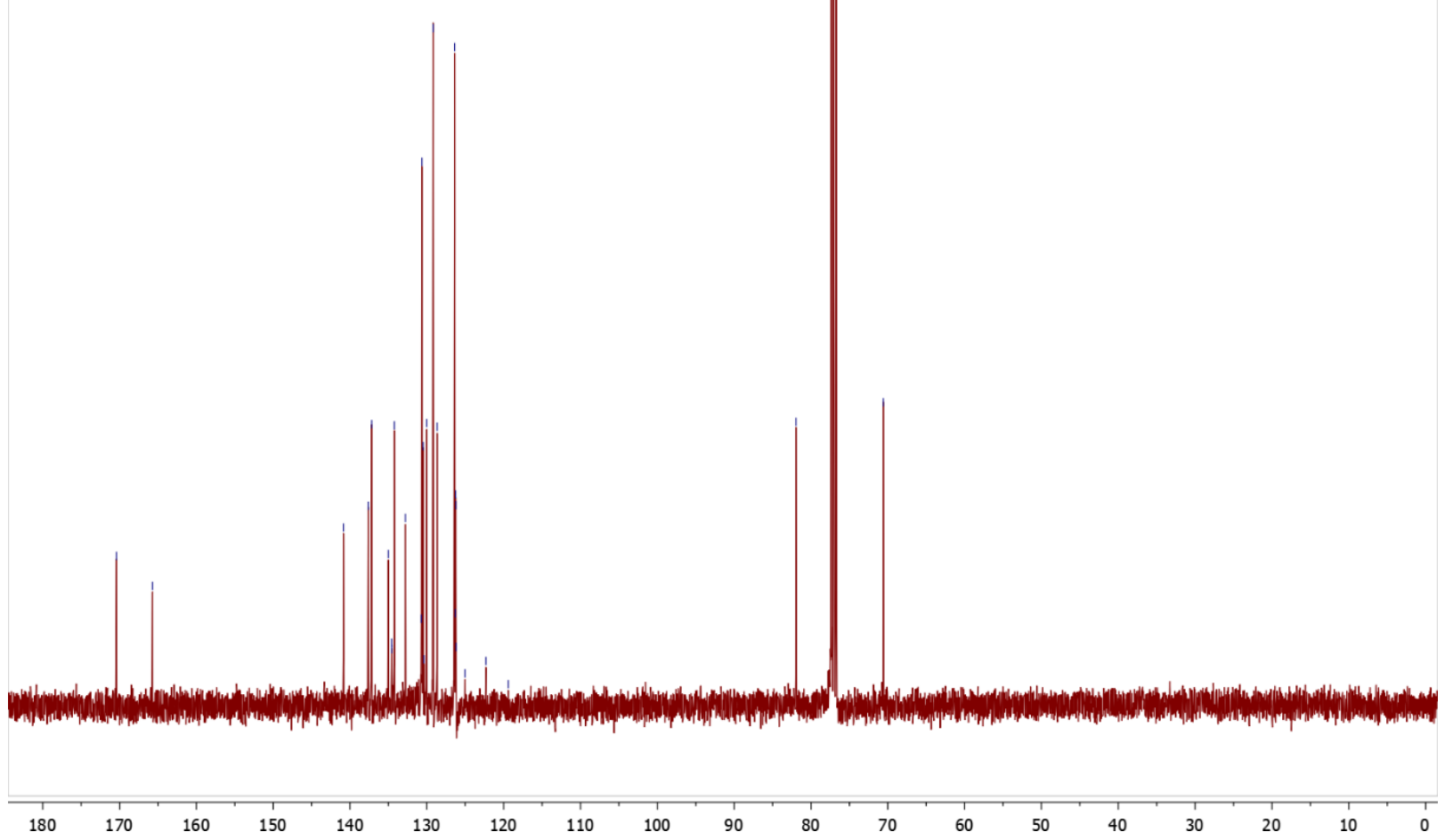
Copy of ${ }^{19} \mathrm{~F}\left\{{ }^{1} \mathrm{H}\right\} \quad\left(376.50 \mathrm{MHz}, \mathrm{CDCl}_{3}\right)$ spectrum of $\mathbf{2 o}$

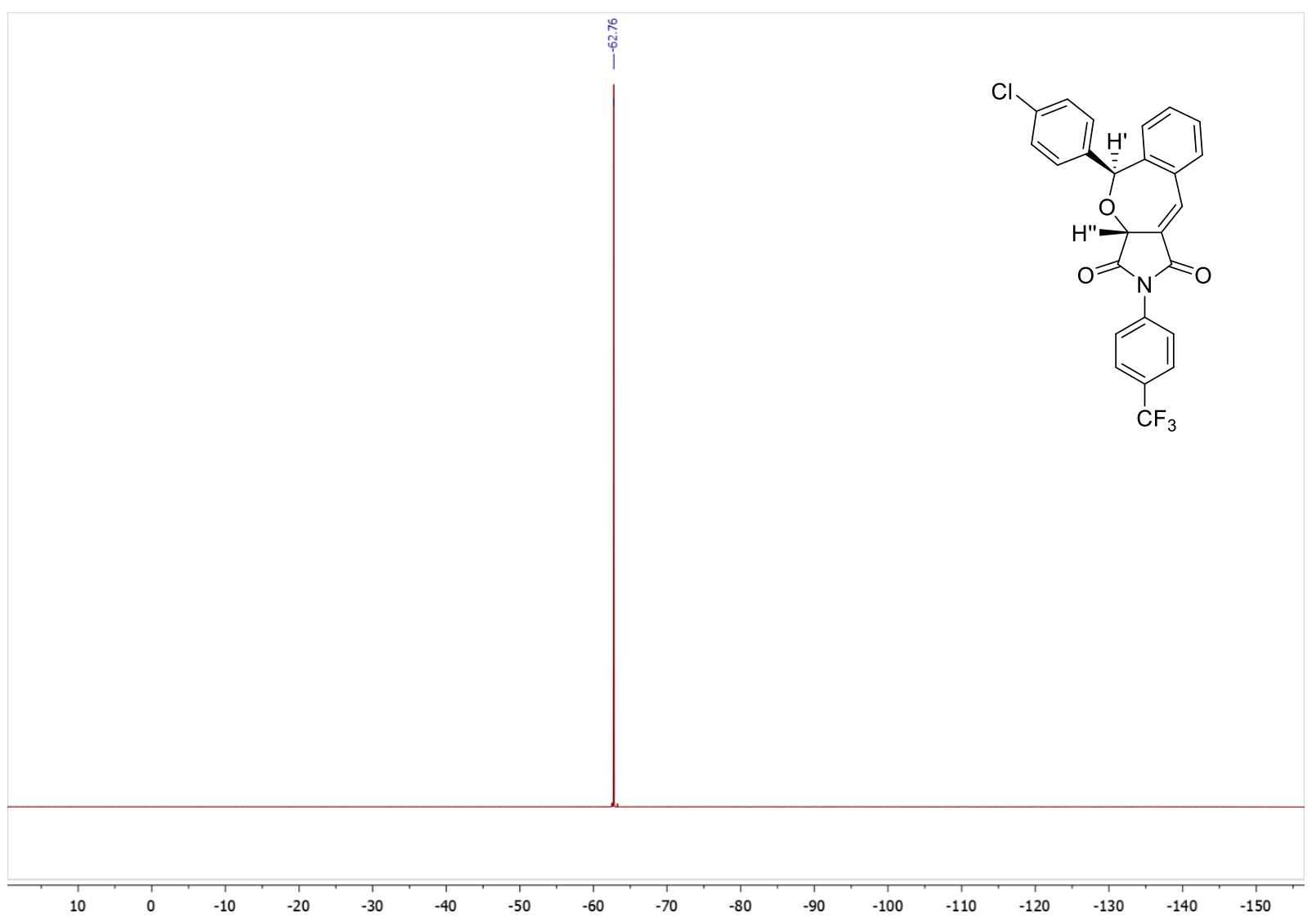


Copies of ${ }^{1} \mathrm{H}\left(400.13 \mathrm{MHz}, \mathrm{CDCl}_{3}\right)$ and ${ }^{13} \mathrm{C}\left\{{ }^{1} \mathrm{H}\right\}\left(100.61 \mathrm{MHz}, \mathrm{CDCl}_{3}\right)$ spectra of $3 \mathbf{o}$

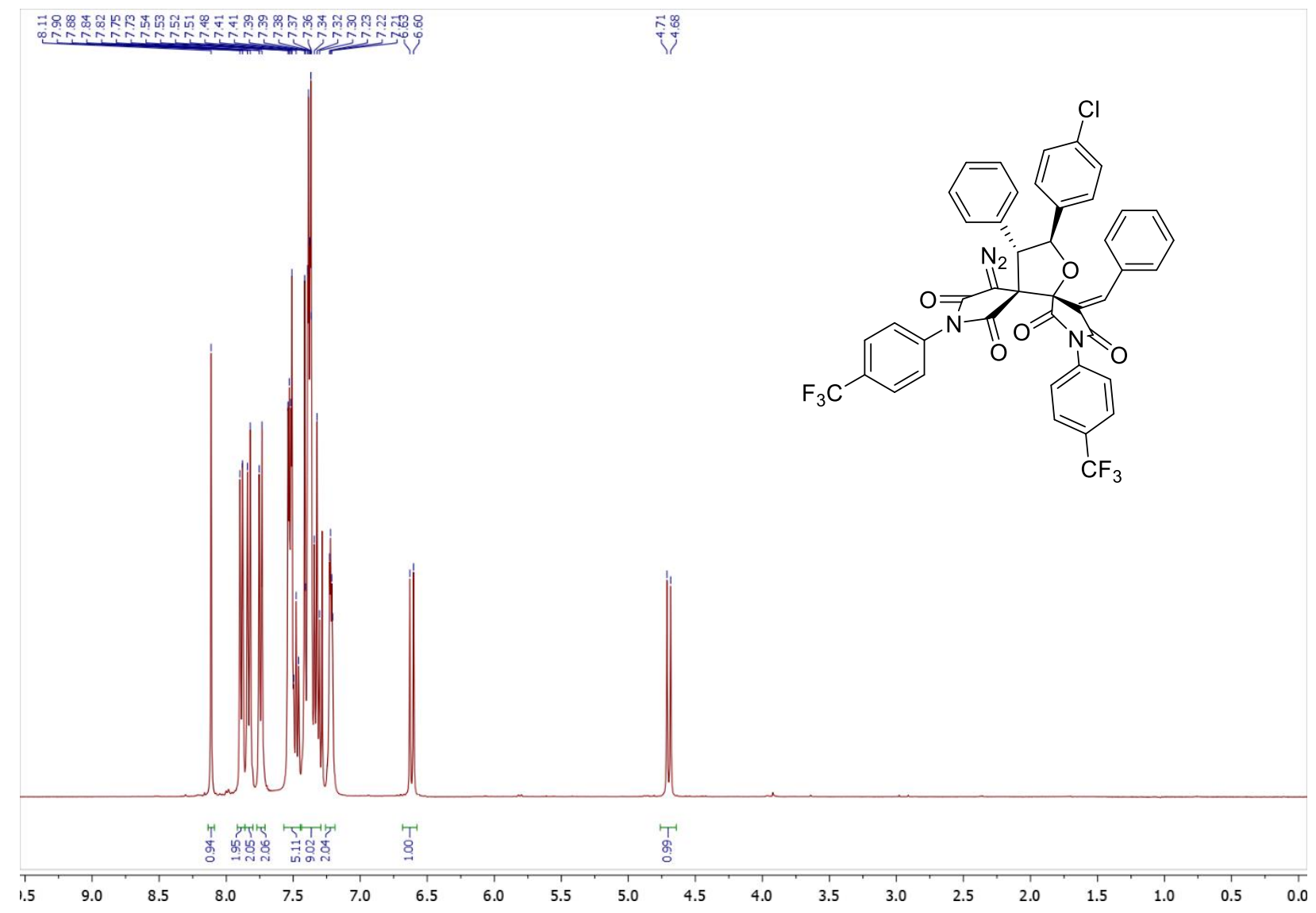

影藉
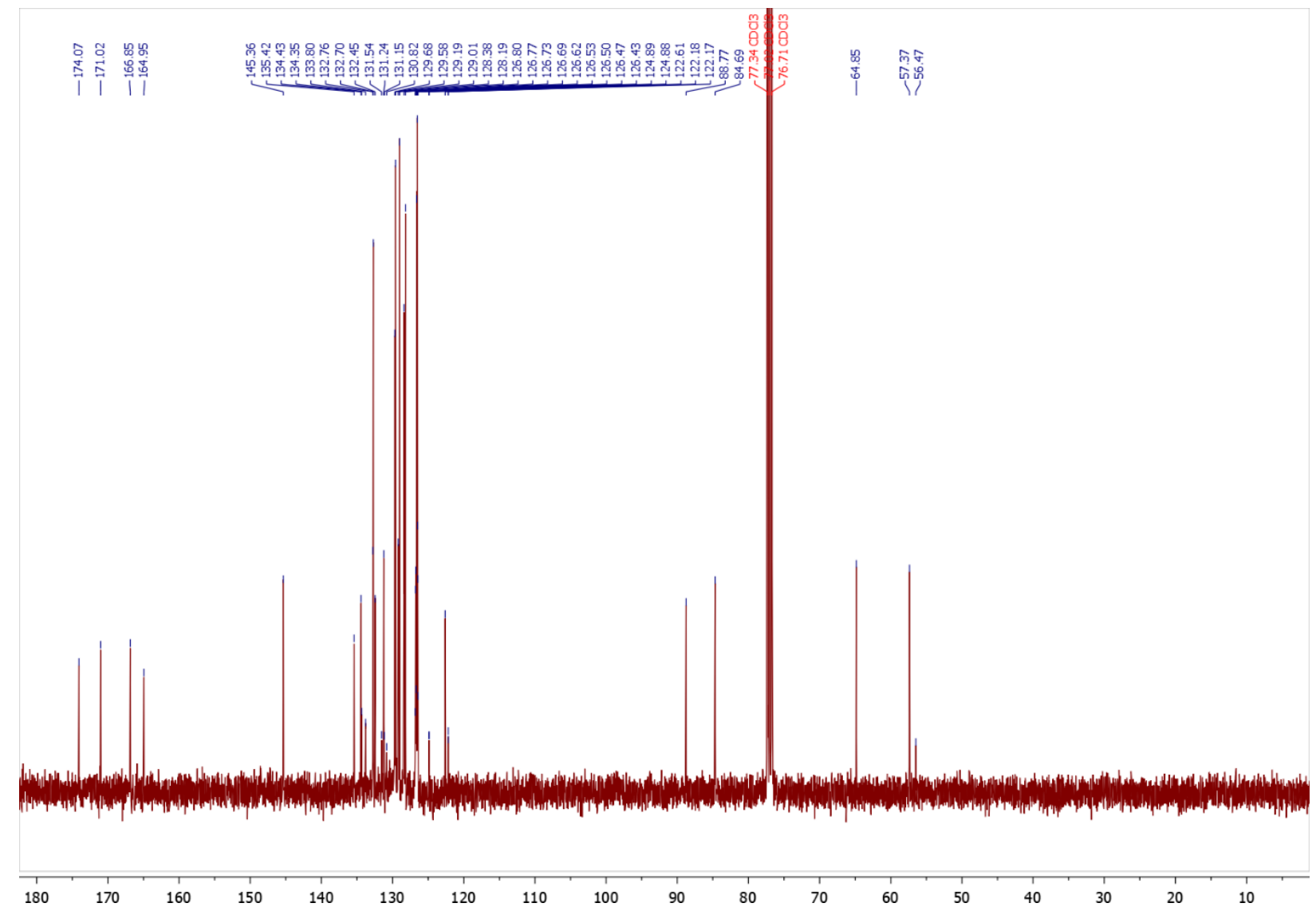
Copy of ${ }^{19} \mathrm{~F}\left\{{ }^{1} \mathrm{H}\right\}\left(376.50 \mathrm{MHz}, \mathrm{CDCl}_{3}\right)$ spectrum of $\mathbf{3 o}$

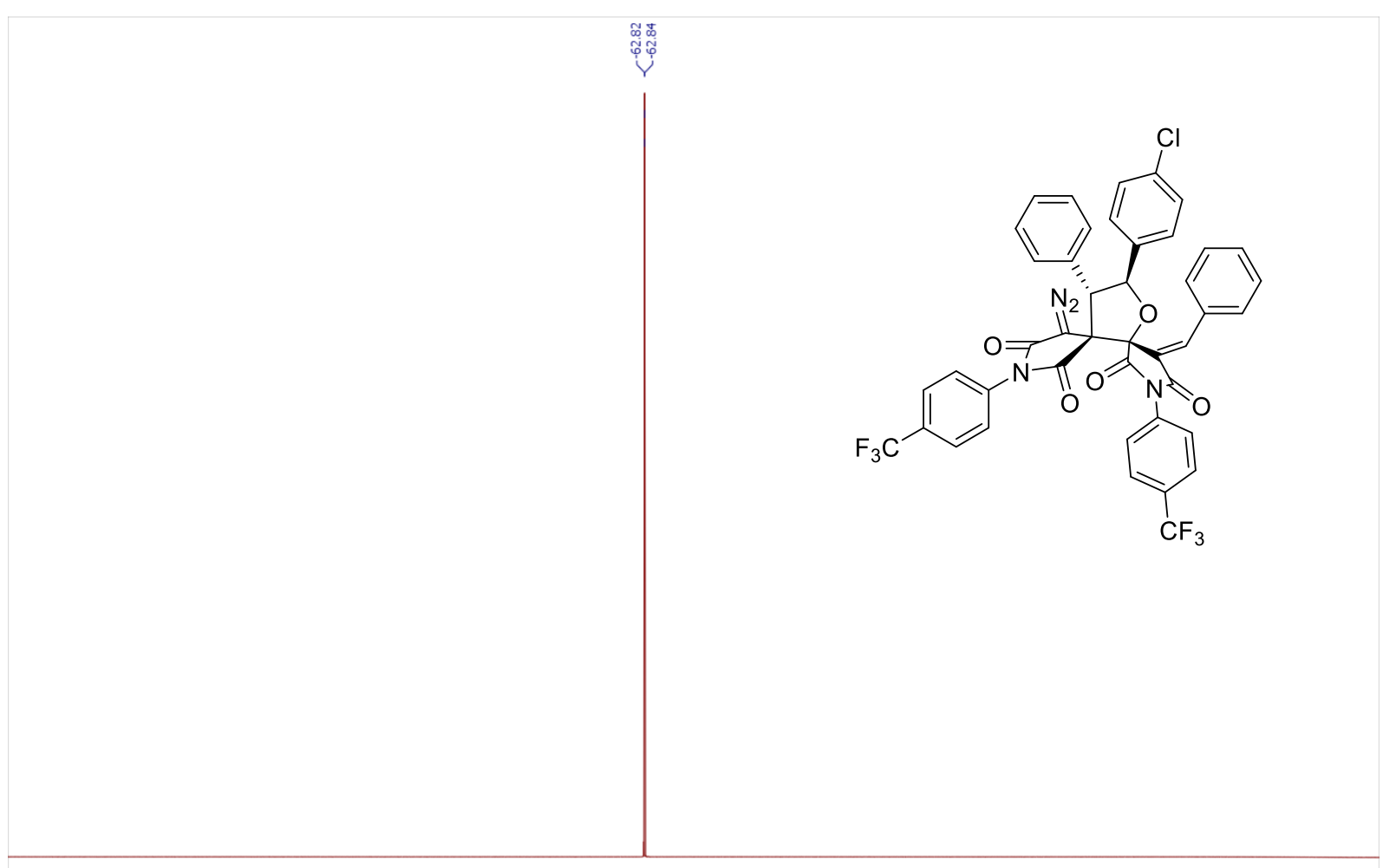

\begin{tabular}{llllllllllllllllllllll}
\hline 0 & 20 & 10 & 0 & -10 & -20 & -30 & -40 & -50 & -60 & -70 & -80 & -90 & -100 & -110 & -120 & -130 & -140 & -150 & -160 & 1
\end{tabular}


Copies of ${ }^{1} \mathrm{H}\left(400.13 \mathrm{MHz}, \mathrm{CDCl}_{3}\right)$ and ${ }^{13} \mathrm{C}\left\{{ }^{1} \mathrm{H}\right\}\left(100.61 \mathrm{MHz}, \mathrm{CDCl}_{3}\right)$ spectra of $\mathbf{2 p}$

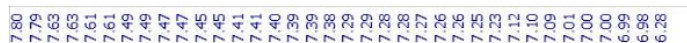
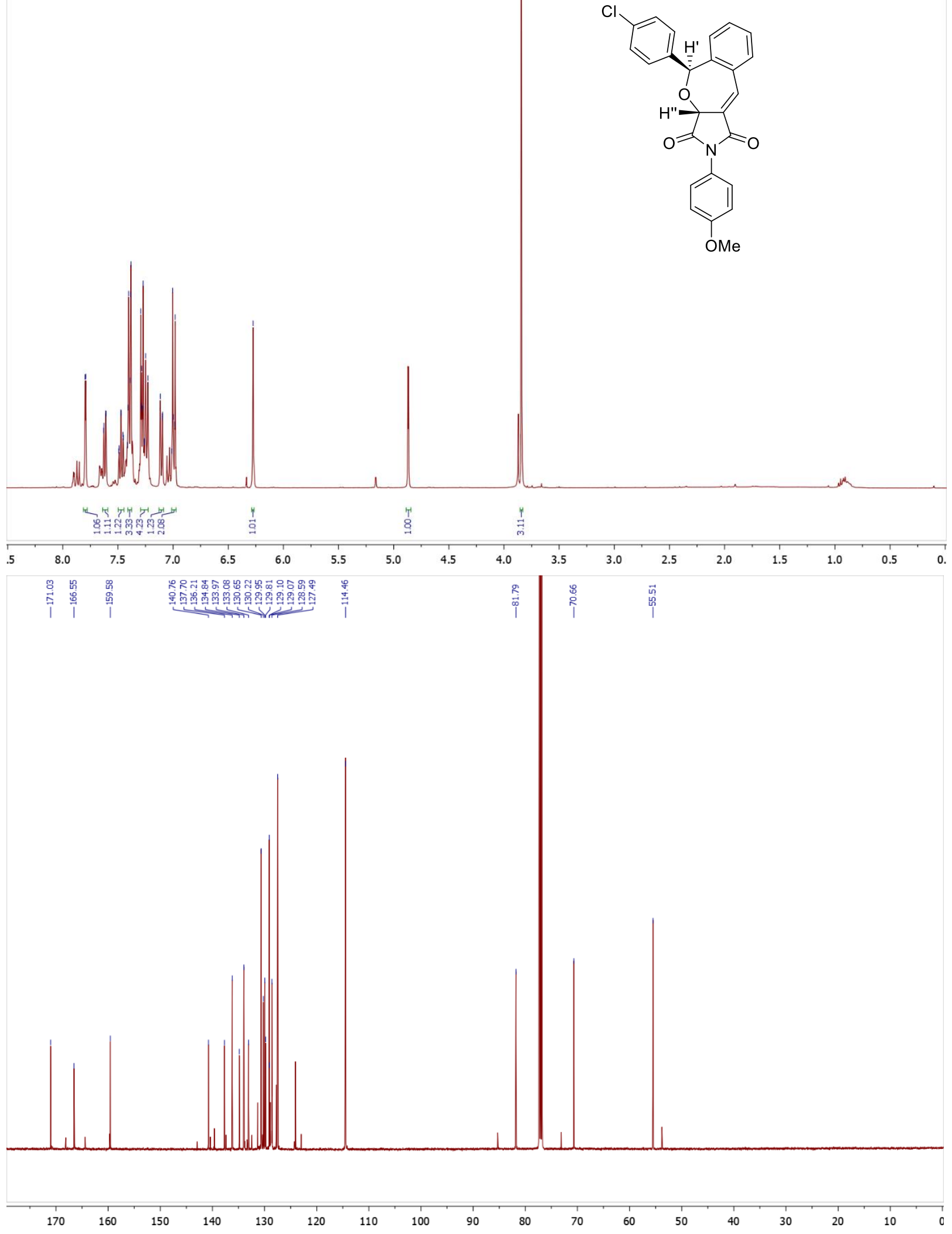

S36 
Copy of NOESY spectrum of $\mathbf{2 p}$

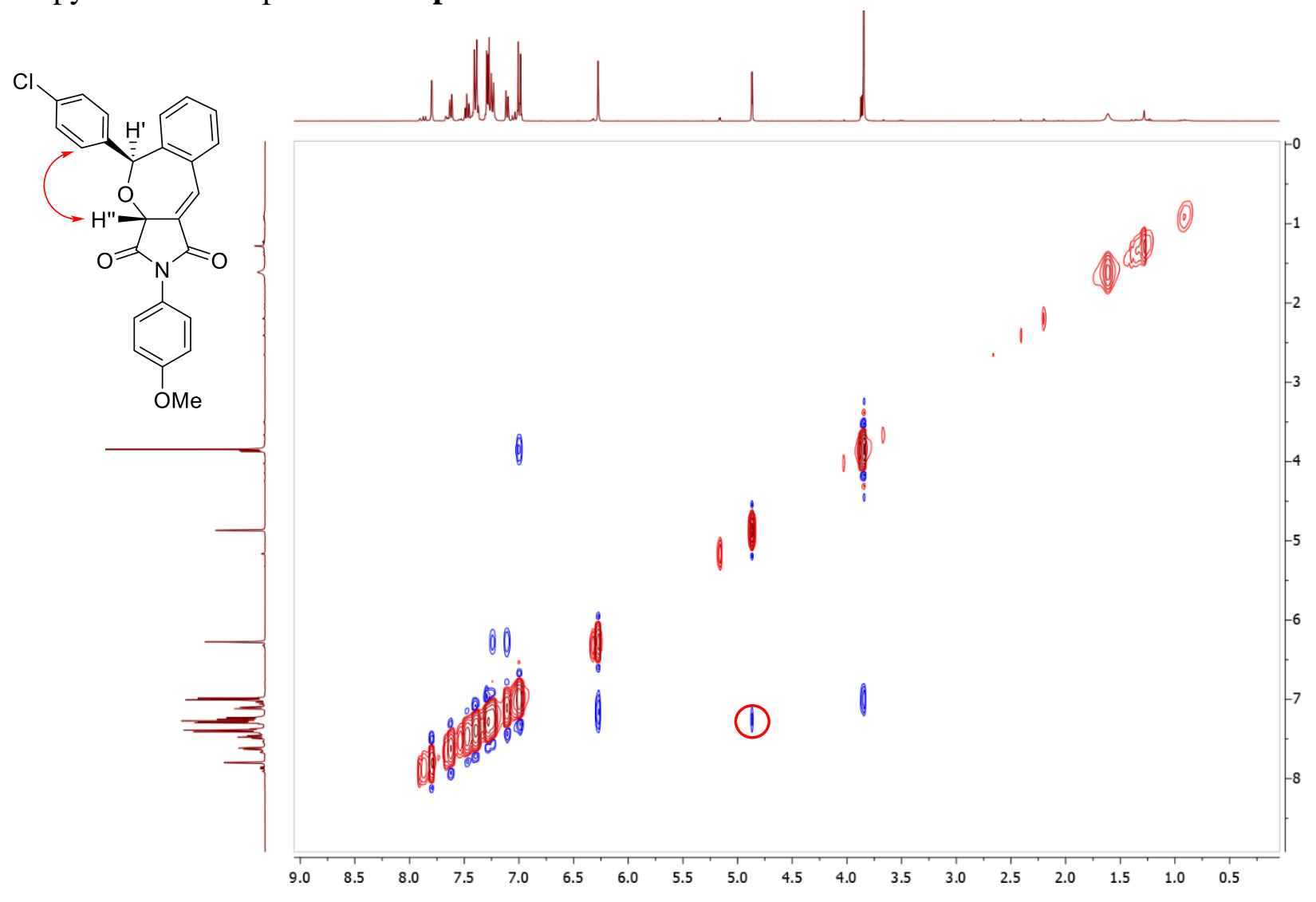

S37 
Copies of ${ }^{1} \mathrm{H}\left(400.13 \mathrm{MHz}, \mathrm{CDCl}_{3}\right)$ and ${ }^{13} \mathrm{C}\left\{{ }^{1} \mathrm{H}\right\}\left(100.61 \mathrm{MHz}, \mathrm{CDCl}_{3}\right)$ spectra of $\mathbf{3 p}$
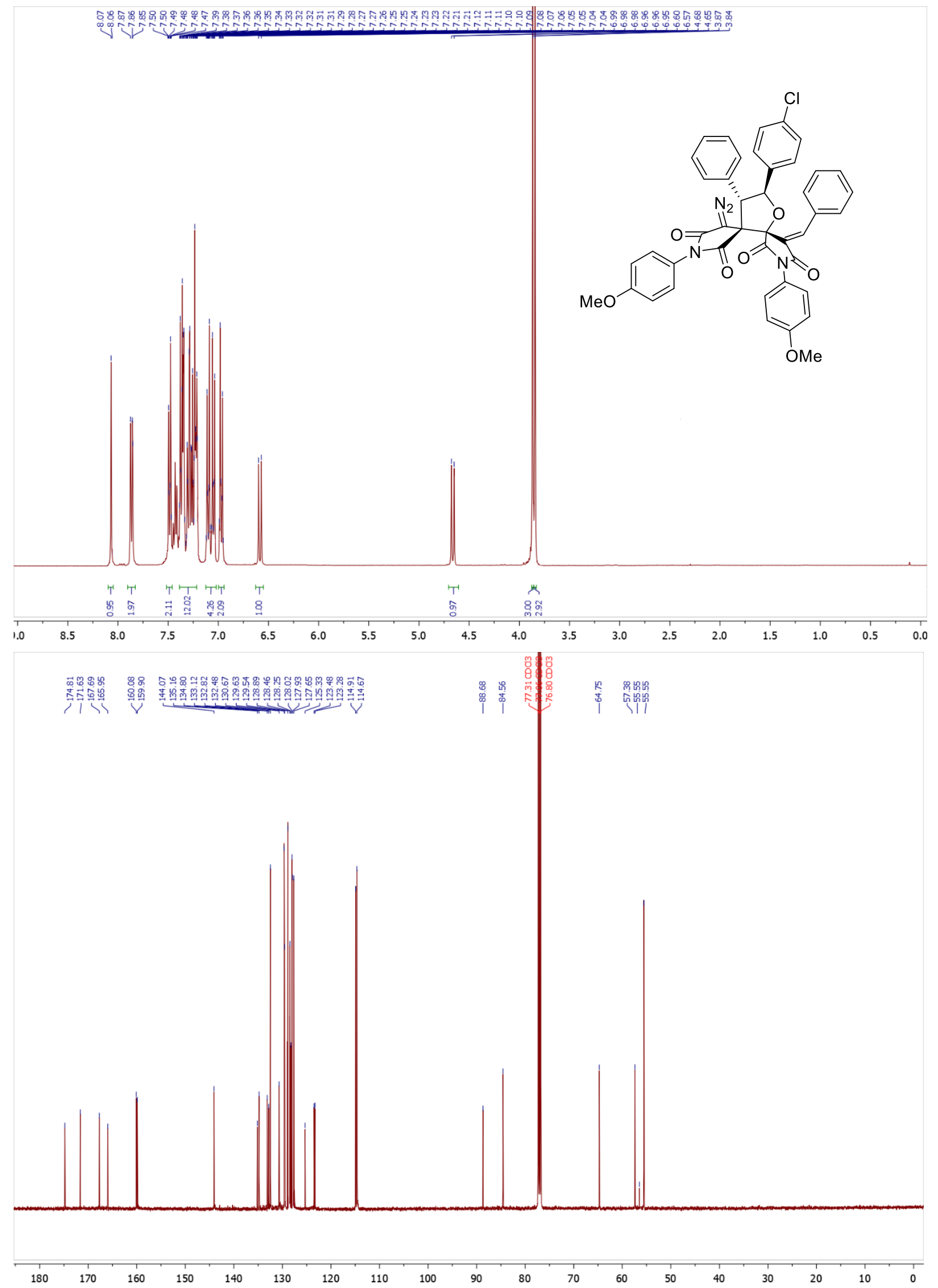
Copies of ${ }^{1} \mathrm{H}\left(400.13 \mathrm{MHz}, \mathrm{CDCl}_{3}\right)$ and ${ }^{13} \mathrm{C}\left\{{ }^{1} \mathrm{H}\right\}\left(100.61 \mathrm{MHz}, \mathrm{CDCl}_{3}\right)$ spectra of $\mathbf{2 q}$
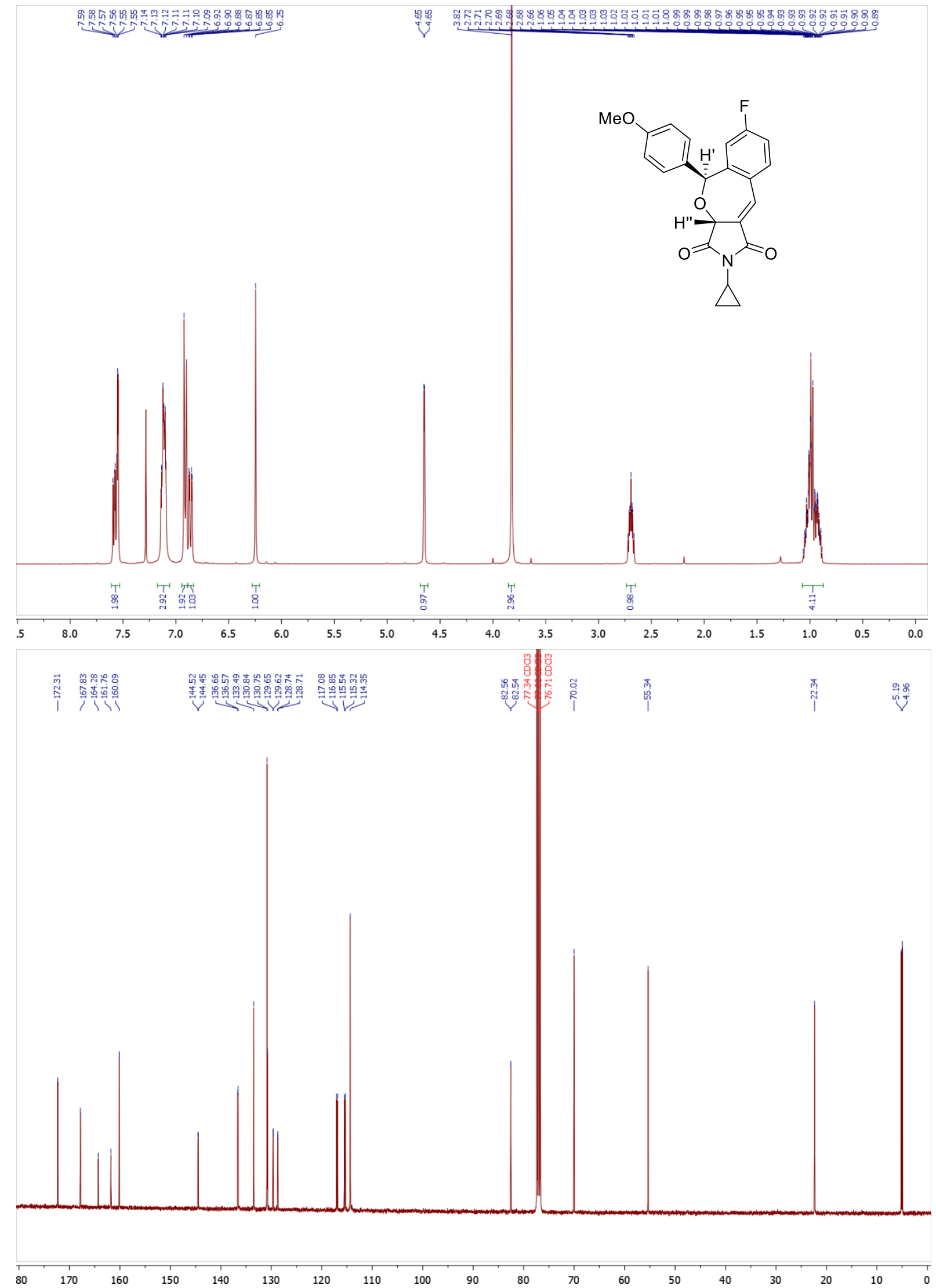
Copies of ${ }^{19} \mathrm{~F}\left\{{ }^{1} \mathrm{H}\right\}\left(376.50 \mathrm{MHz}, \mathrm{CDCl}_{3}\right)$ spectrum and NOESY spectrum of $\mathbf{2 q}$

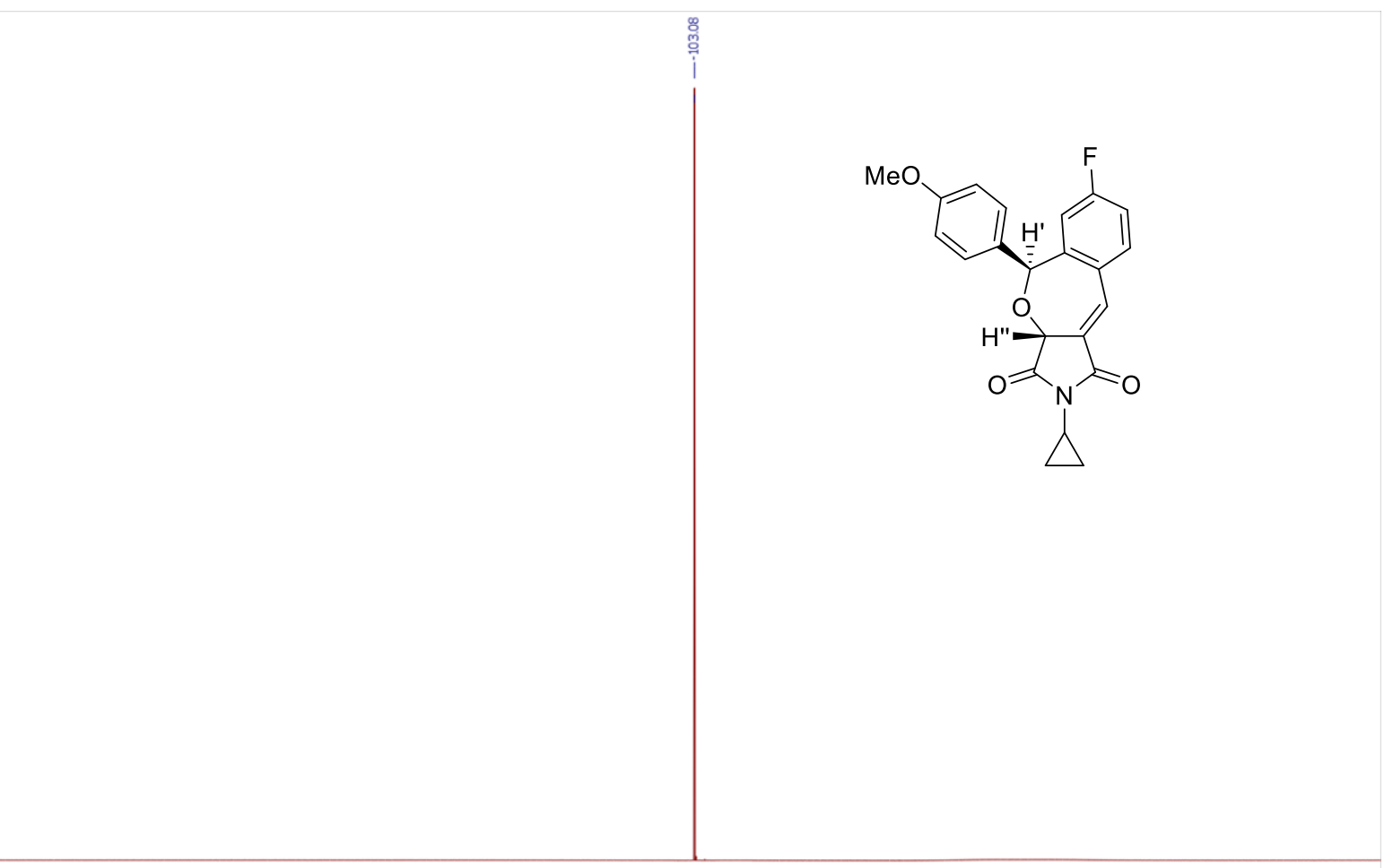

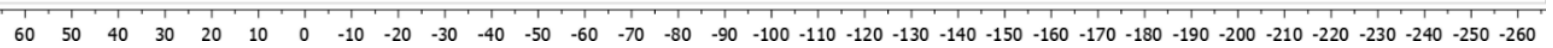
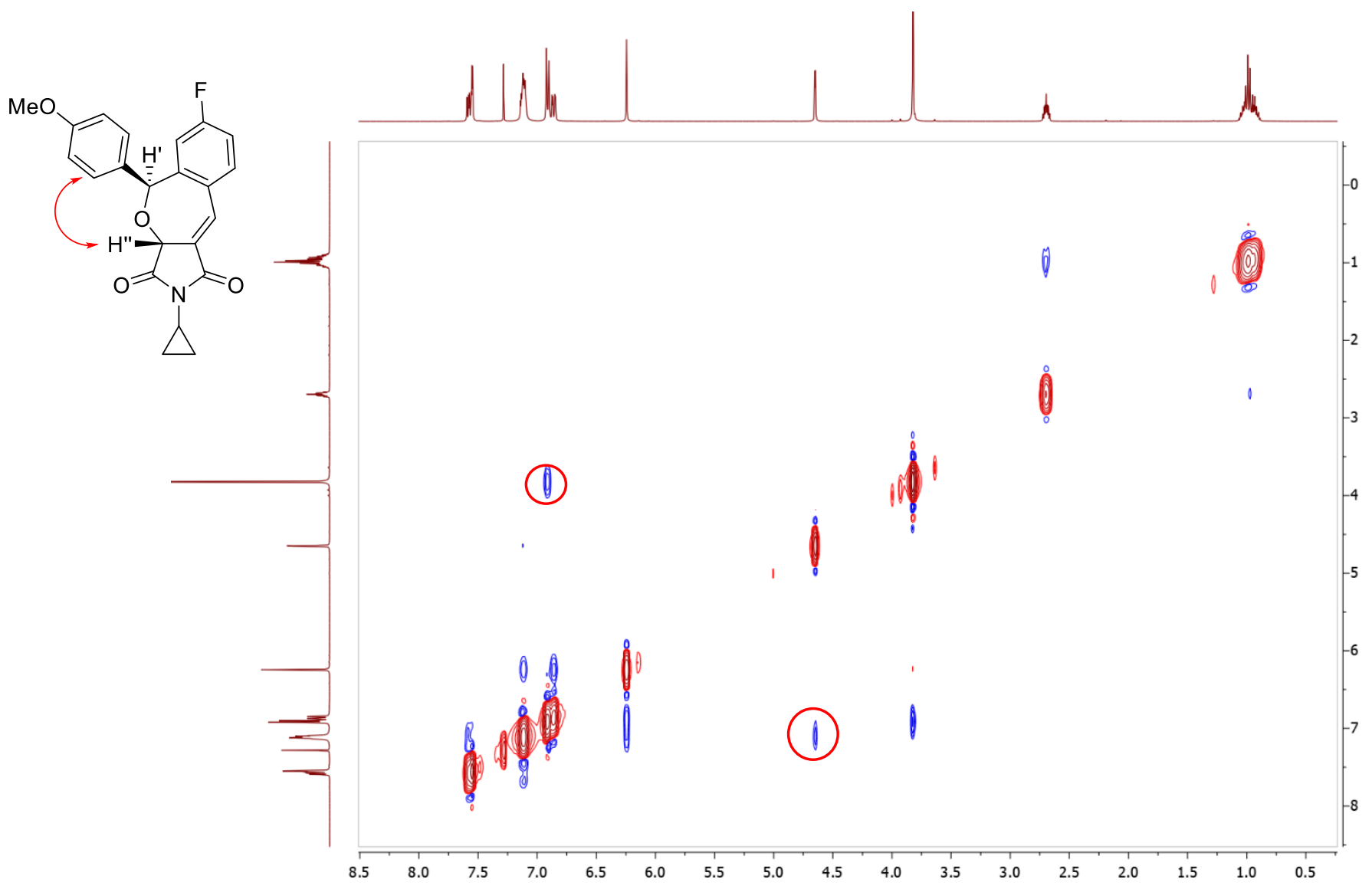
Copies of ${ }^{1} \mathrm{H}\left(400.13 \mathrm{MHz}, \mathrm{CDCl}_{3}\right)$ and ${ }^{13} \mathrm{C}\left\{{ }^{1} \mathrm{H}\right\}\left(100.61 \mathrm{MHz}, \mathrm{CDCl}_{3}\right)$ spectra of $\mathbf{2 r}$
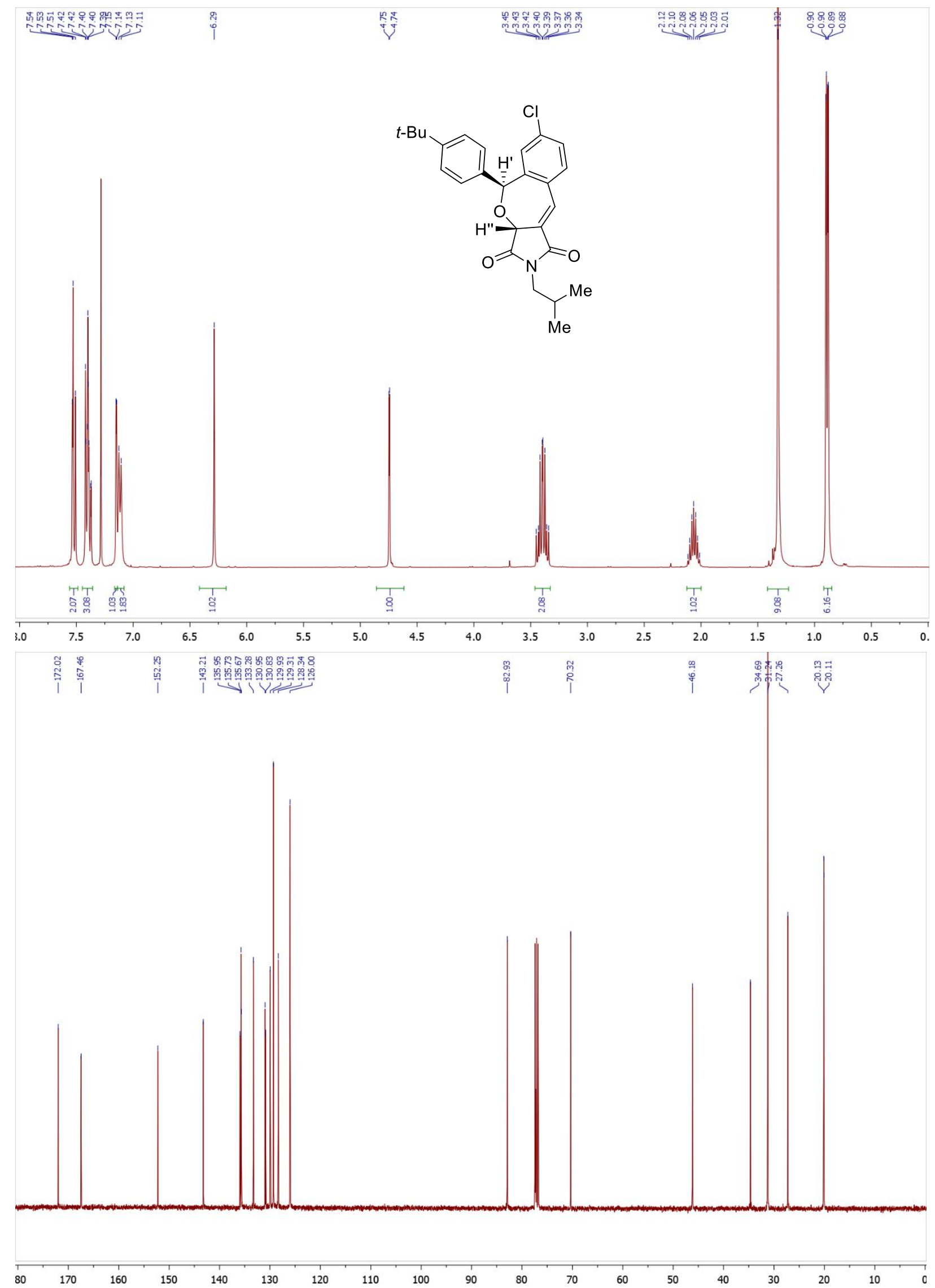
Copy of NOESY spectrum of $\mathbf{2 r}$

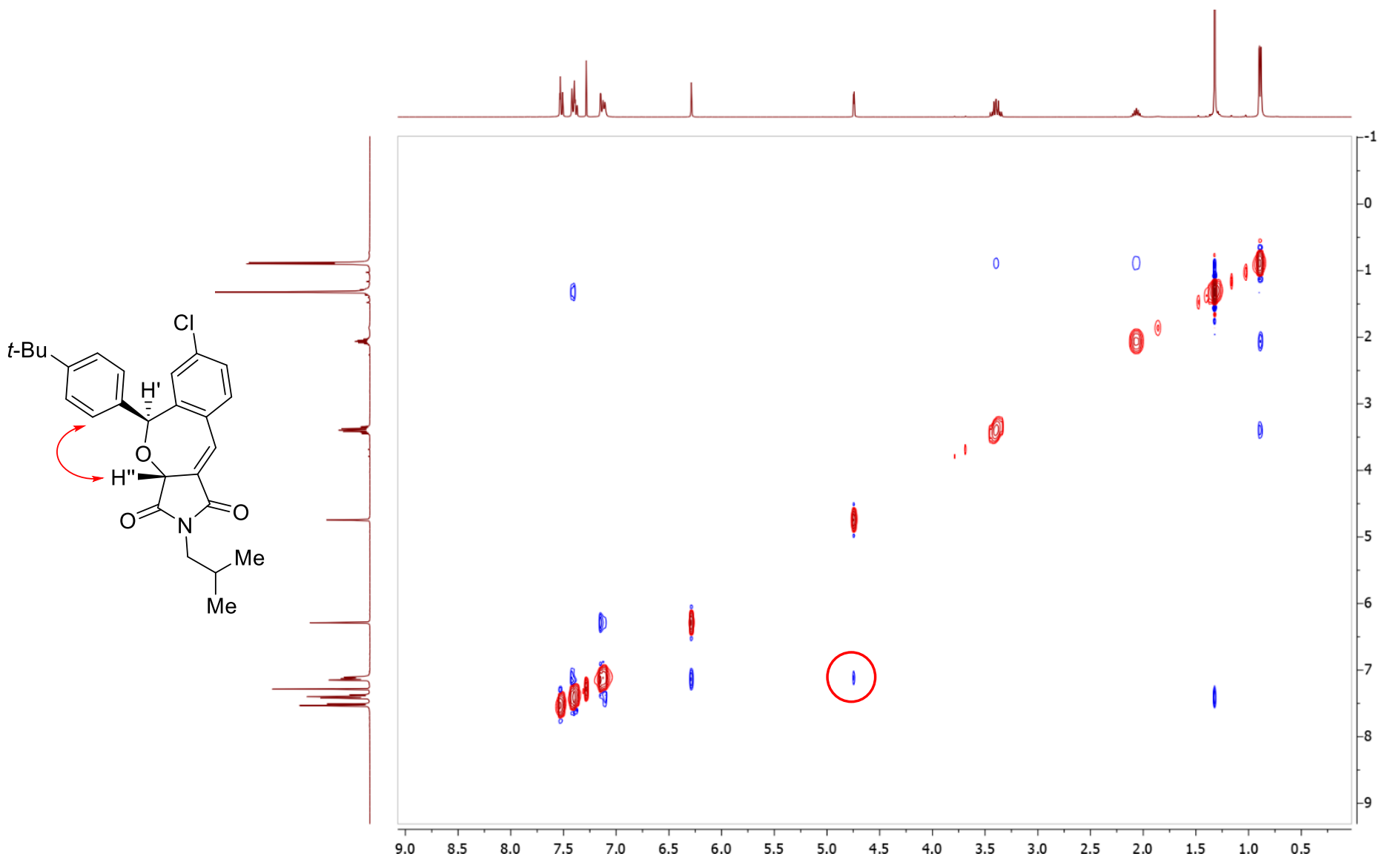


Copies of ${ }^{1} \mathrm{H}\left(400.13 \mathrm{MHz}, \mathrm{CDCl}_{3}\right)$ and ${ }^{13} \mathrm{C}\left\{{ }^{1} \mathrm{H}\right\}\left(100.61 \mathrm{MHz}, \mathrm{CDCl}_{3}\right)$ spectra of $2 \mathrm{~s}$
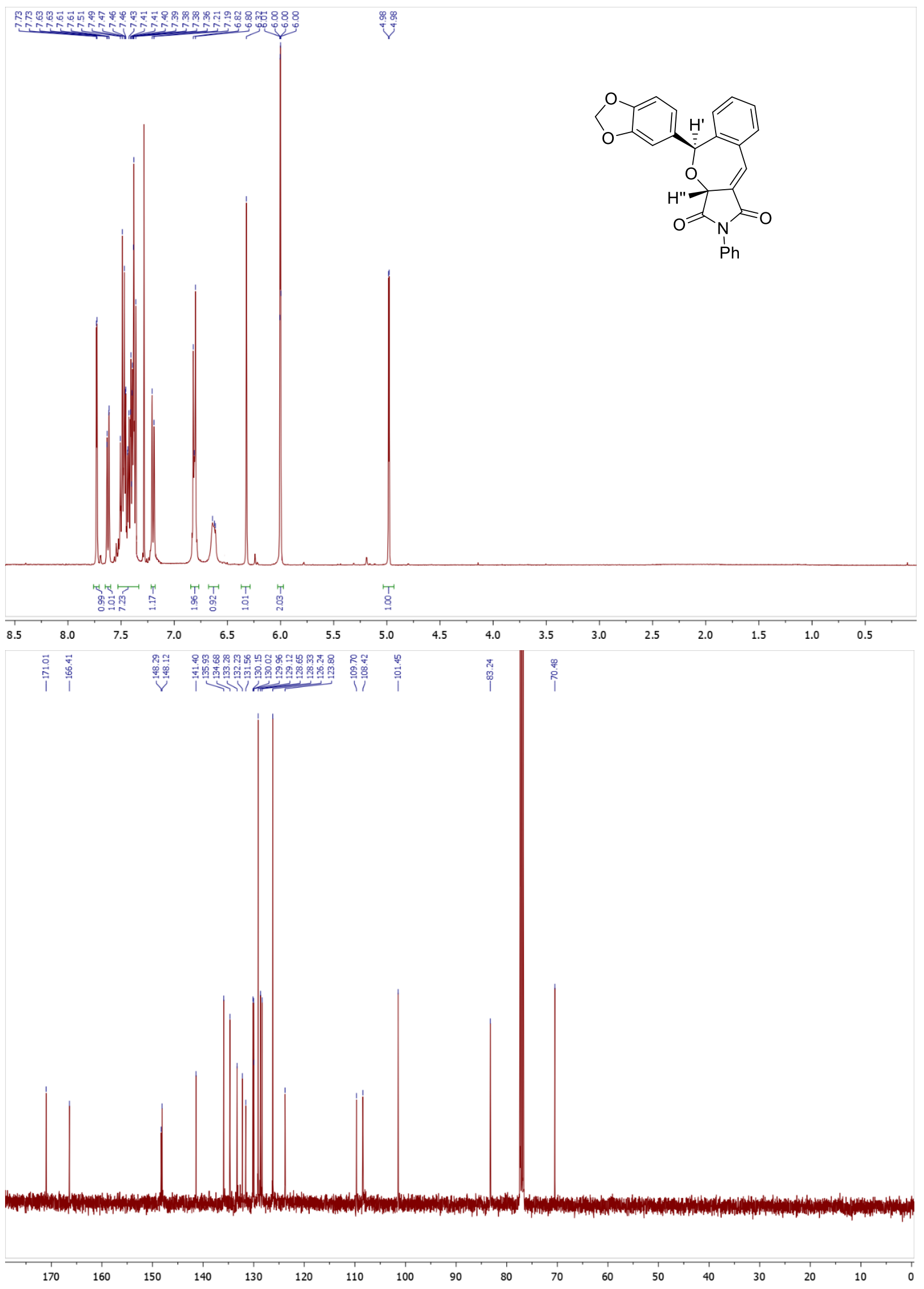
Copies of ${ }^{1} \mathrm{H}\left(400.13 \mathrm{MHz}, \mathrm{CDCl}_{3}\right)$ and ${ }^{13} \mathrm{C}\left\{{ }^{1} \mathrm{H}\right\}\left(100.61 \mathrm{MHz}, \mathrm{CDCl}_{3}\right)$ spectra of $\mathbf{2 t}$

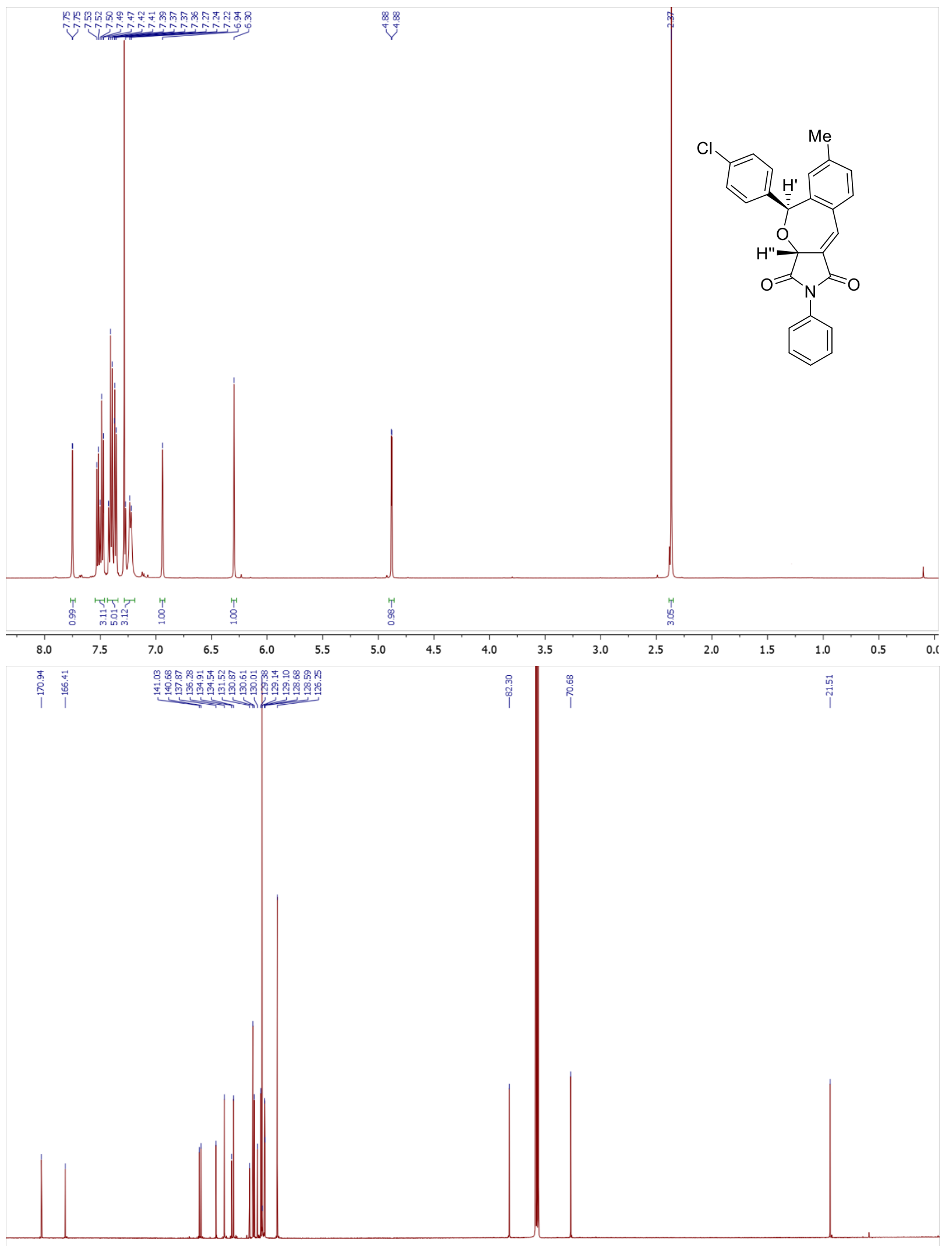

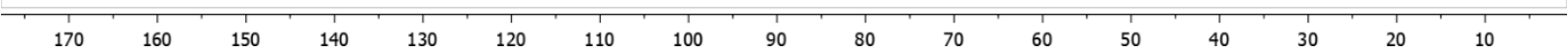


Copy of NOESY spectrum of $\mathbf{2 t}$

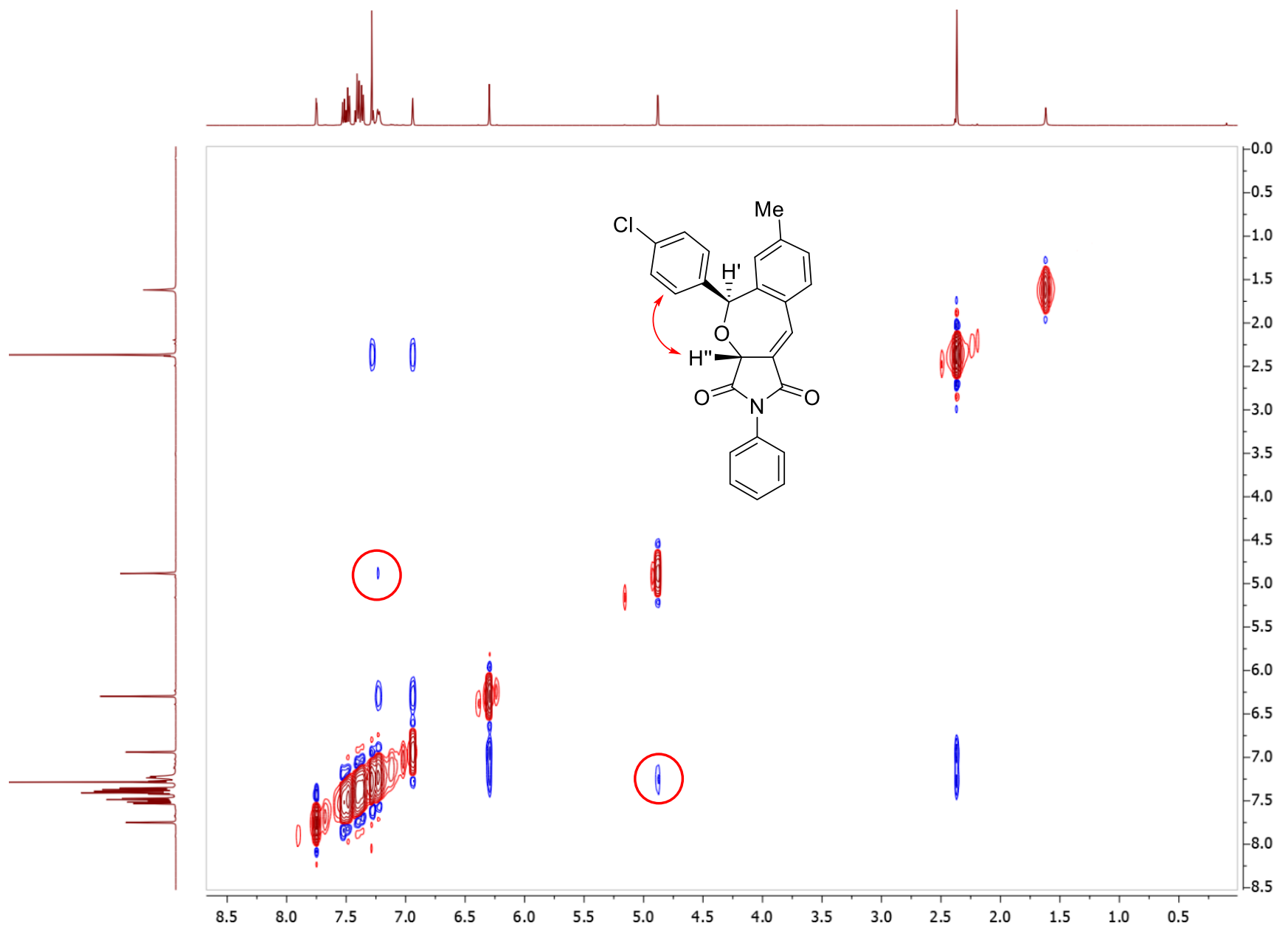


Copies of ${ }^{1} \mathrm{H}\left(400.13 \mathrm{MHz}, \mathrm{CDCl}_{3}\right)$ and ${ }^{13} \mathrm{C}\left\{{ }^{1} \mathrm{H}\right\}\left(100.61 \mathrm{MHz}, \mathrm{CDCl}_{3}\right)$ spectra of $\mathbf{3 t}$

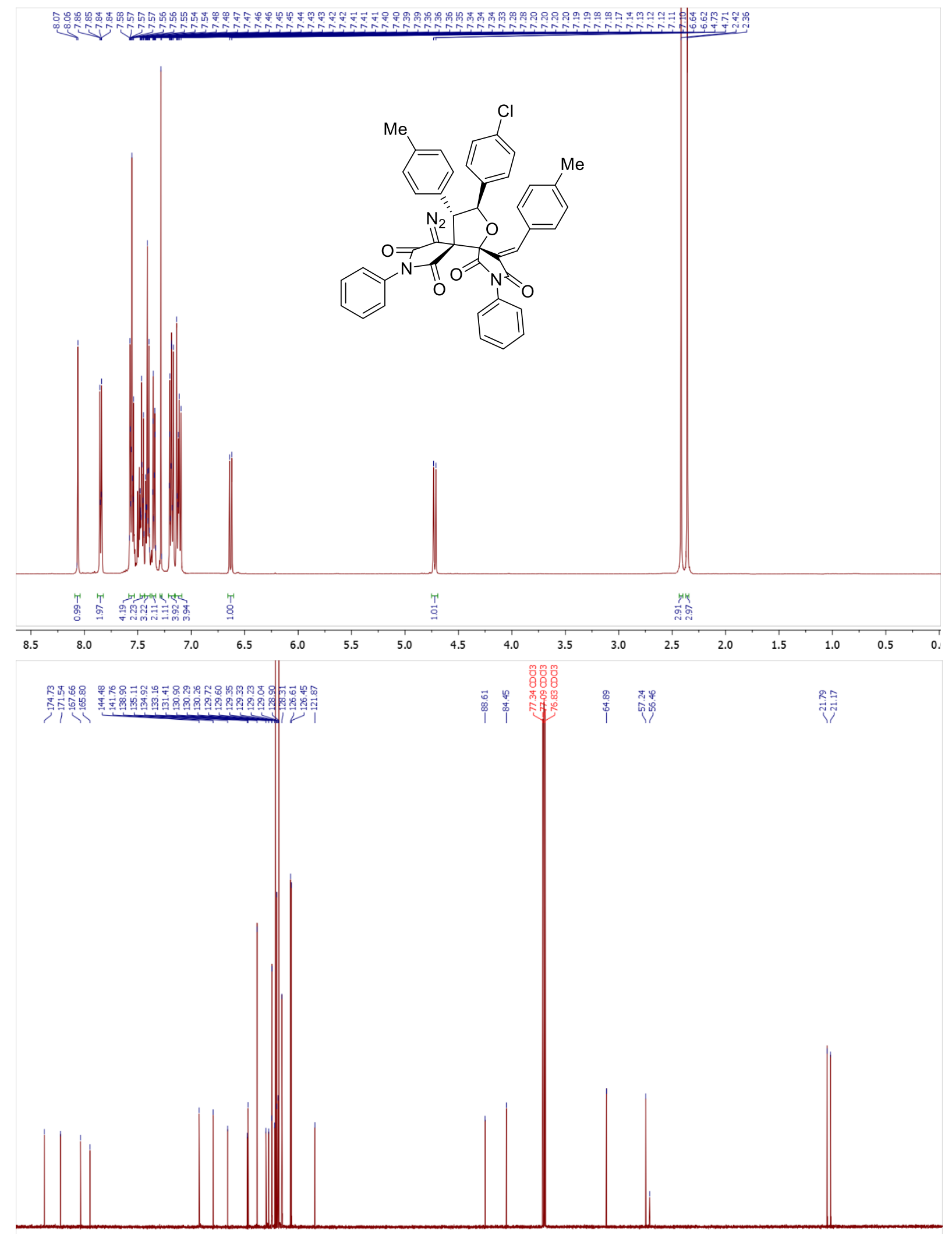

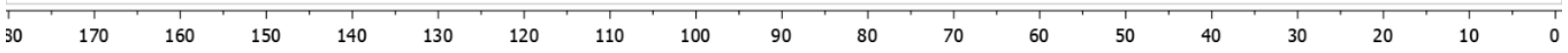


Copies of ${ }^{1} \mathrm{H}\left(400.13 \mathrm{MHz}, \mathrm{CDCl}_{3}\right)$ and ${ }^{13} \mathrm{C}\left\{{ }^{1} \mathrm{H}\right\}\left(100.61 \mathrm{MHz}, \mathrm{CDCl}_{3}\right)$ spectra of $\mathbf{2 u}$

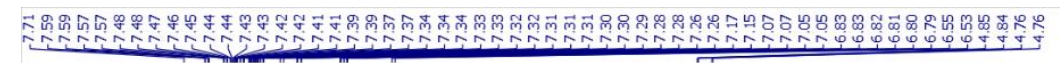
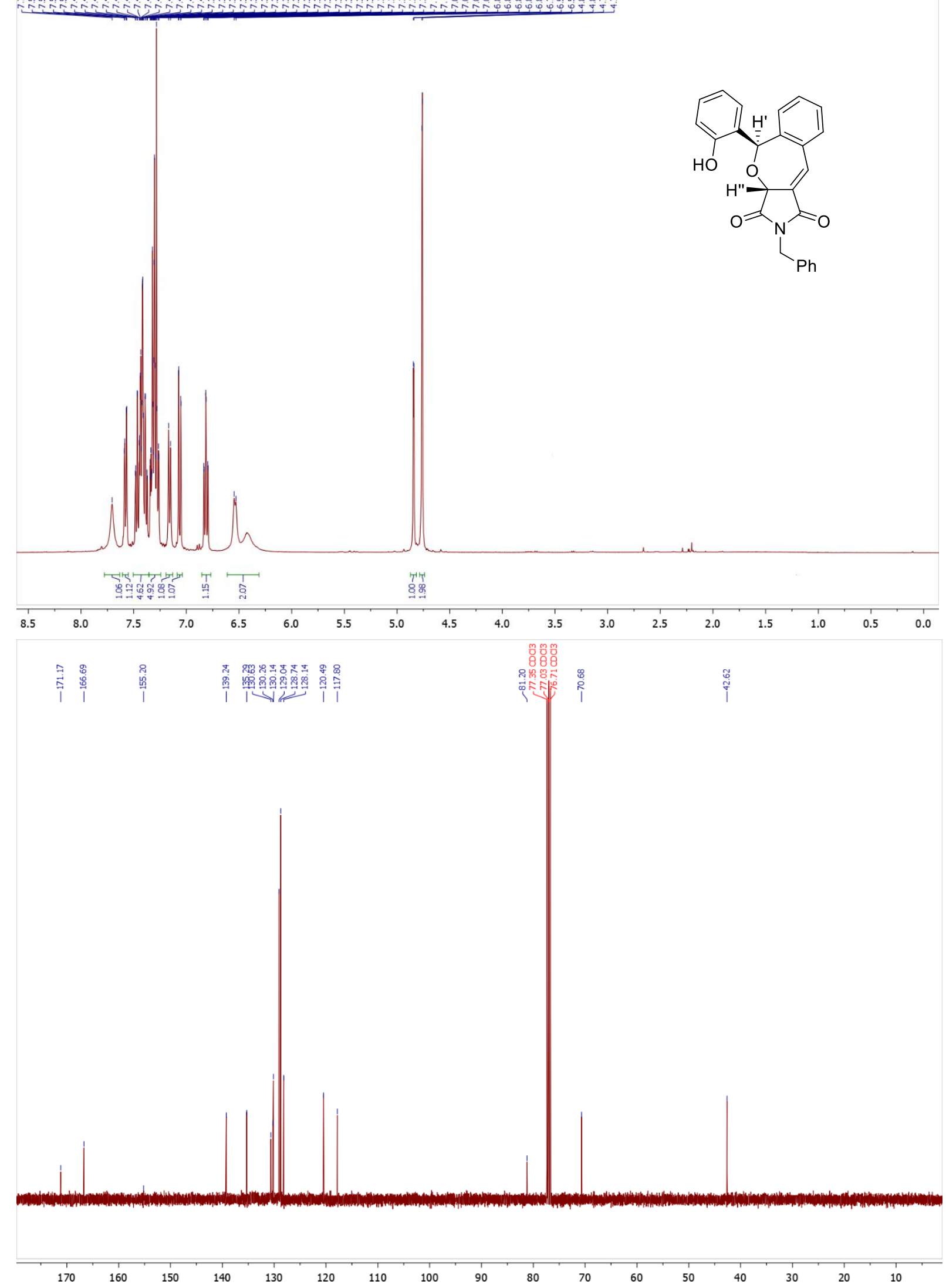
Copy of NOESY spectrum of $\mathbf{2} \mathbf{u}$

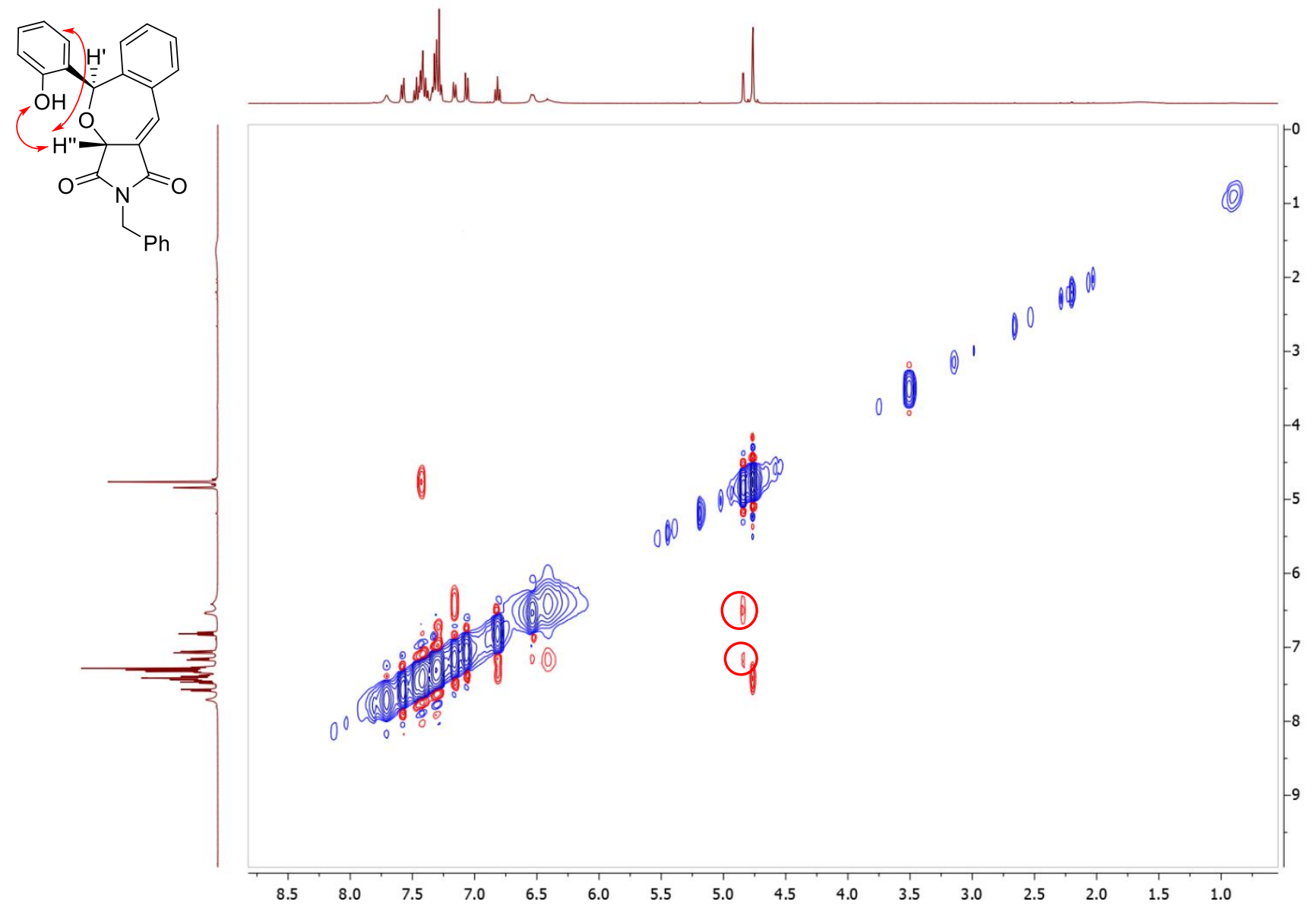


Copies of ${ }^{1} \mathrm{H}\left(400.13 \mathrm{MHz}, \mathrm{CDCl}_{3}\right)$ and ${ }^{13} \mathrm{C}\left\{{ }^{1} \mathrm{H}\right\}\left(100.61 \mathrm{MHz}, \mathrm{CDCl}_{3}\right)$ spectra of $\mathbf{2 v}$

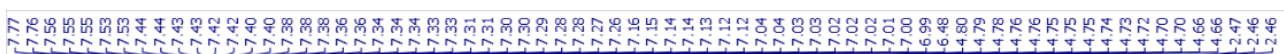

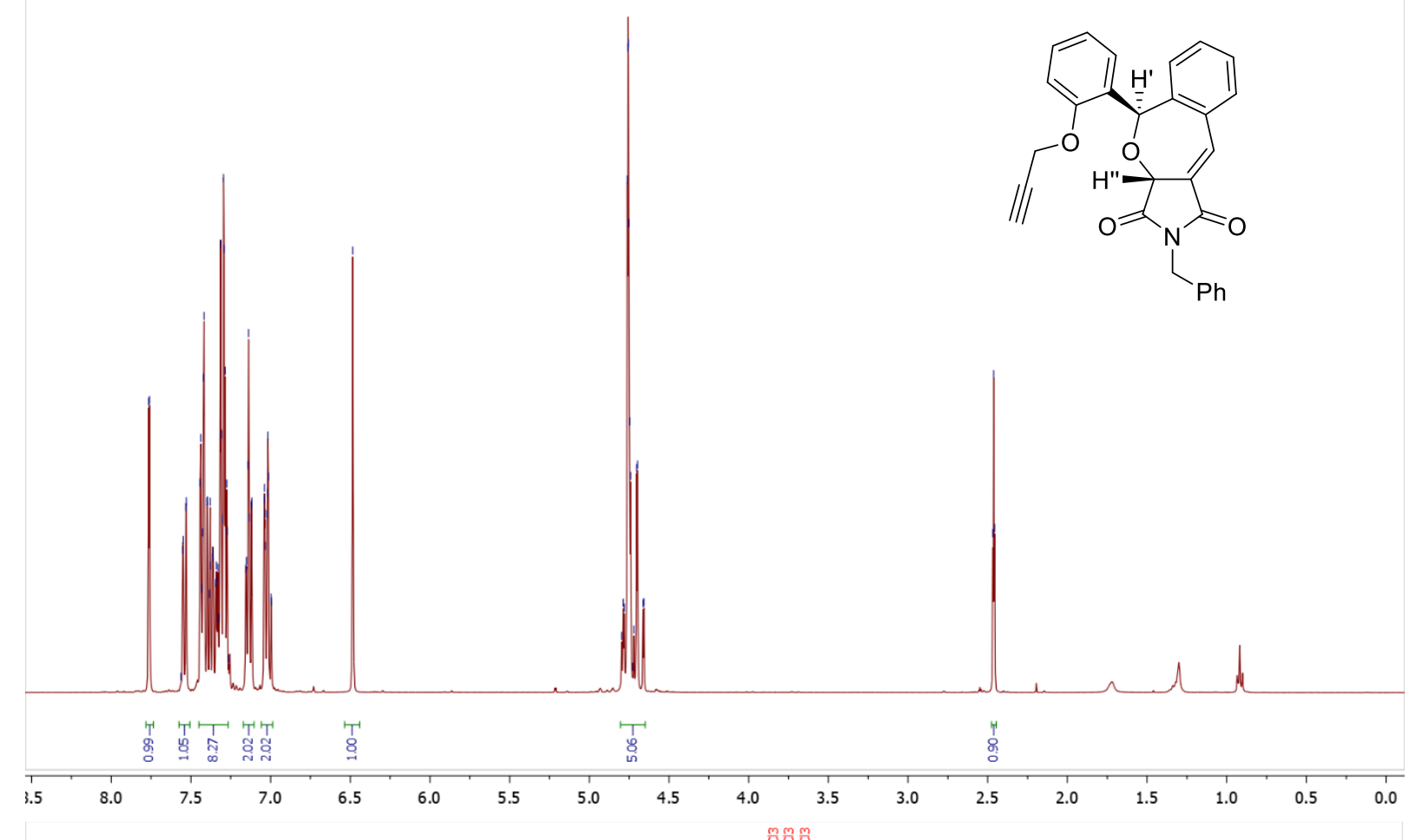

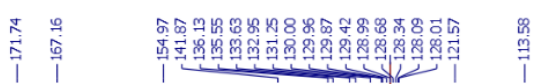

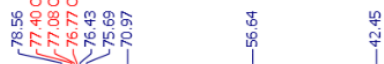
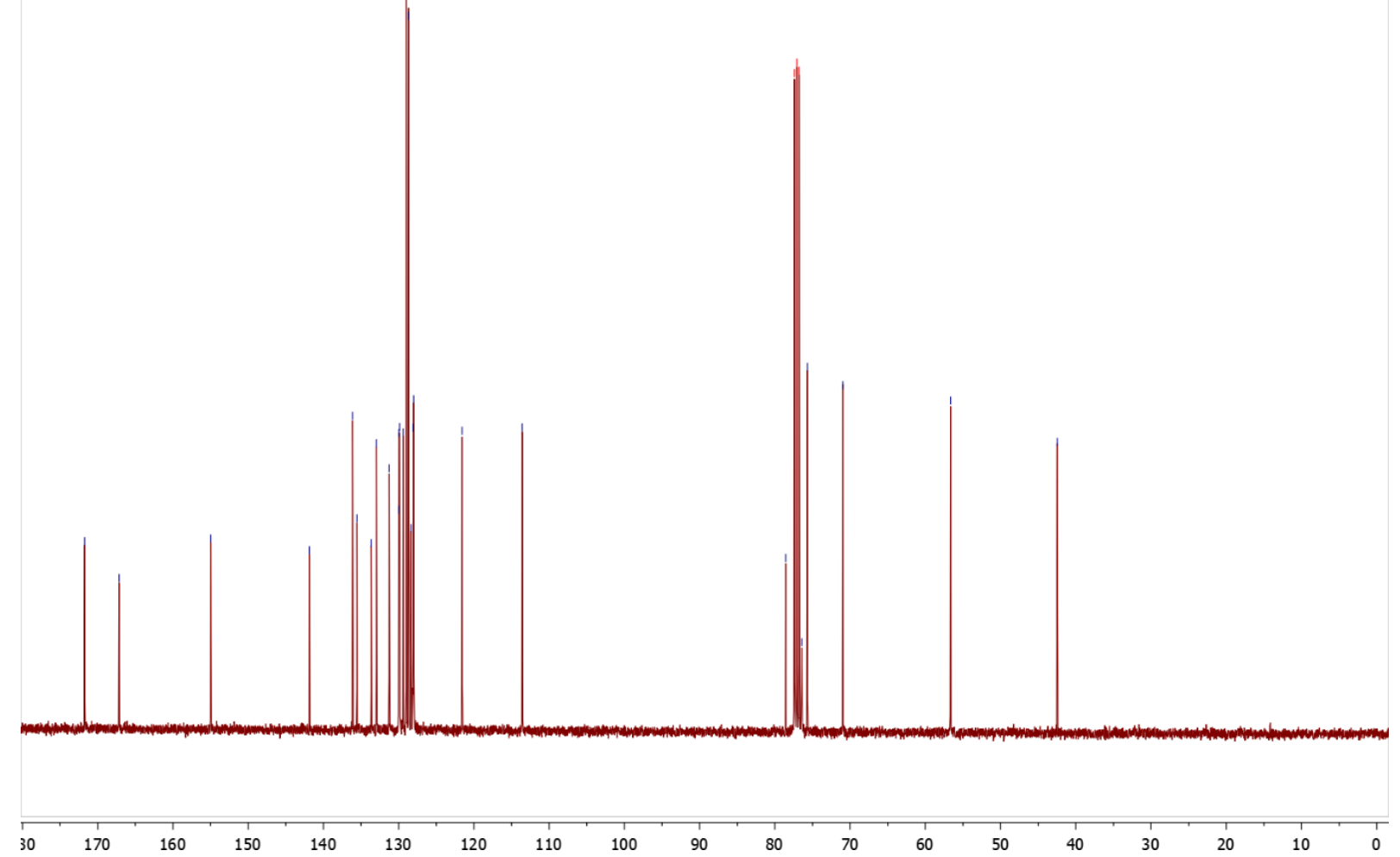
Copies of ${ }^{1} \mathrm{H}\left(400.13 \mathrm{MHz}, \mathrm{CDCl}_{3}\right)$ and ${ }^{13} \mathrm{C}\left\{{ }^{1} \mathrm{H}\right\}\left(100.61 \mathrm{MHz}, \mathrm{CDCl}_{3}\right)$ spectra of $4 \mathbf{a}$
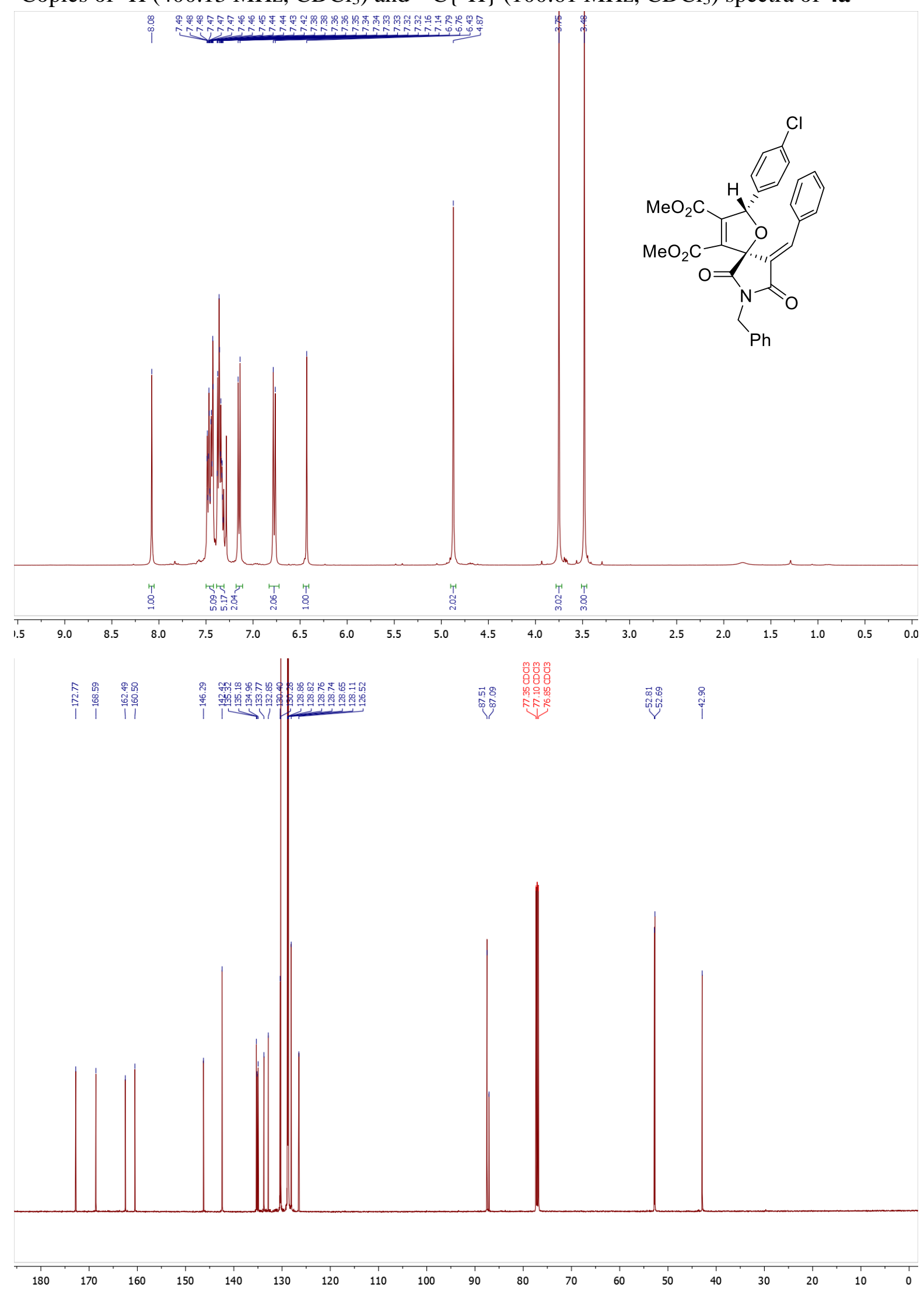
Copy of NOESY spectrum of $\mathbf{4 a}$

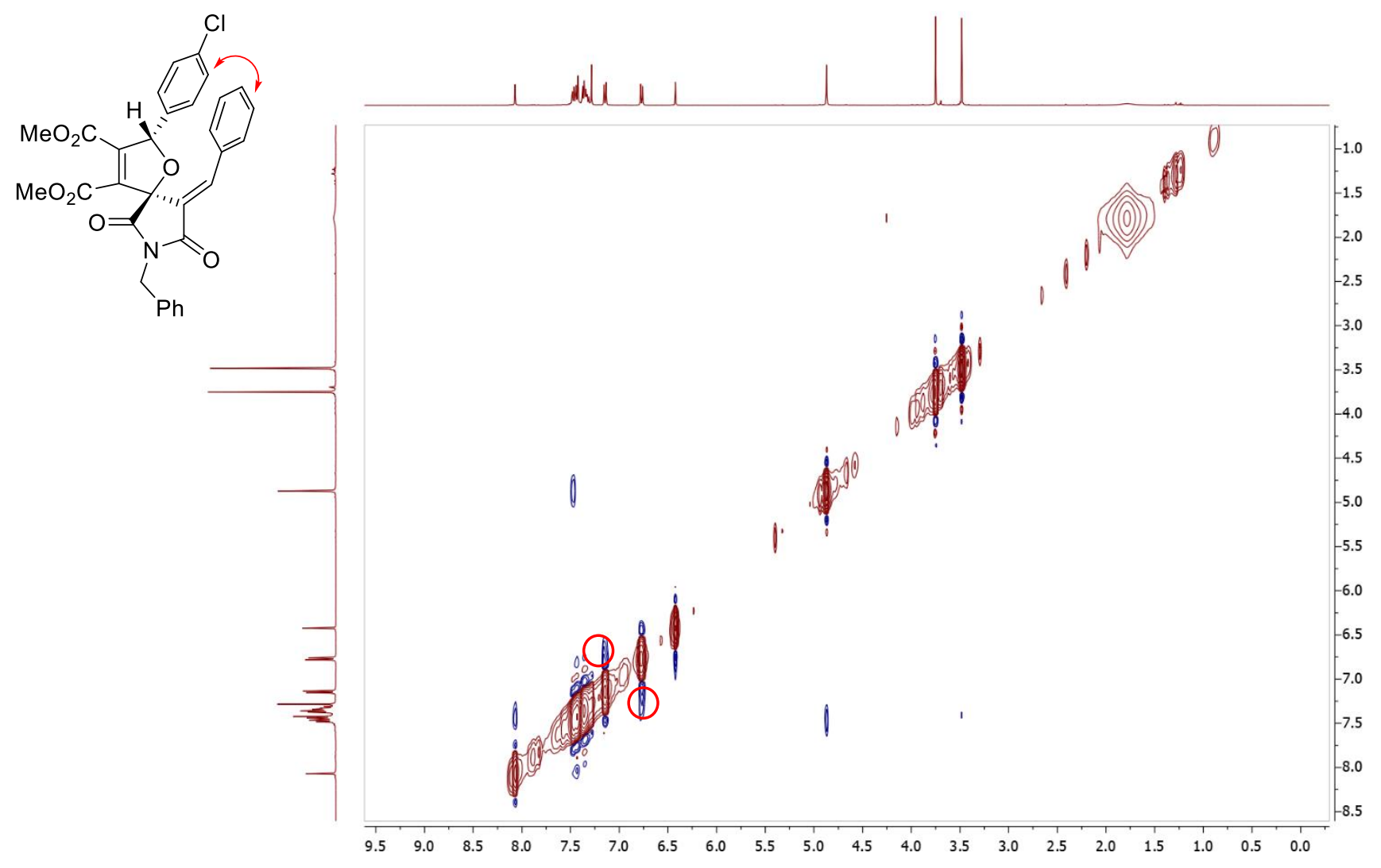


Copies of ${ }^{1} \mathrm{H}\left(400.13 \mathrm{MHz}, \mathrm{CDCl}_{3}\right)$ and ${ }^{13} \mathrm{C}\left\{{ }^{1} \mathrm{H}\right\}\left(100.61 \mathrm{MHz}, \mathrm{CDCl}_{3}\right)$ spectra of $\mathbf{4} \mathbf{b}$
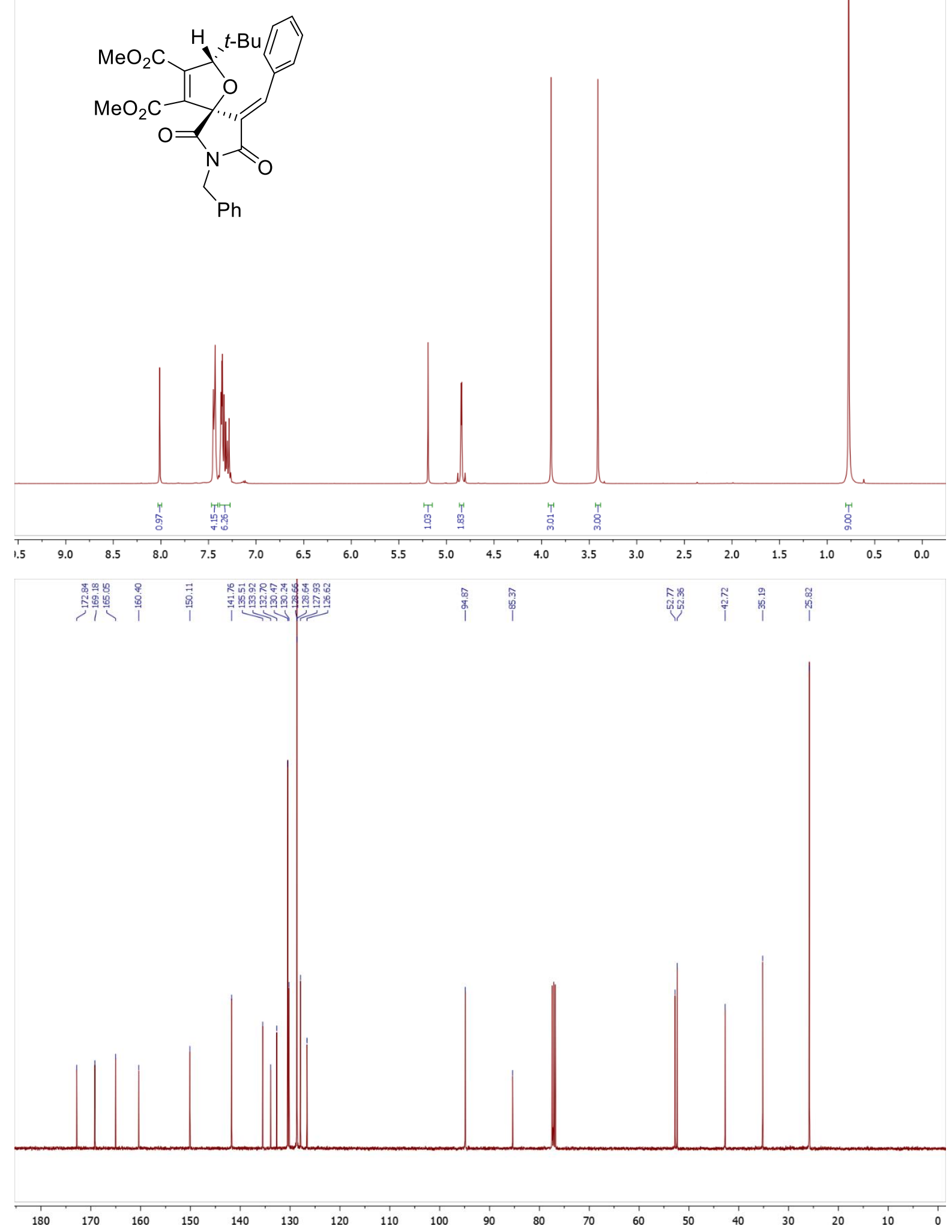


\section{Copy of NOESY spectrum of $\mathbf{4 b}$}

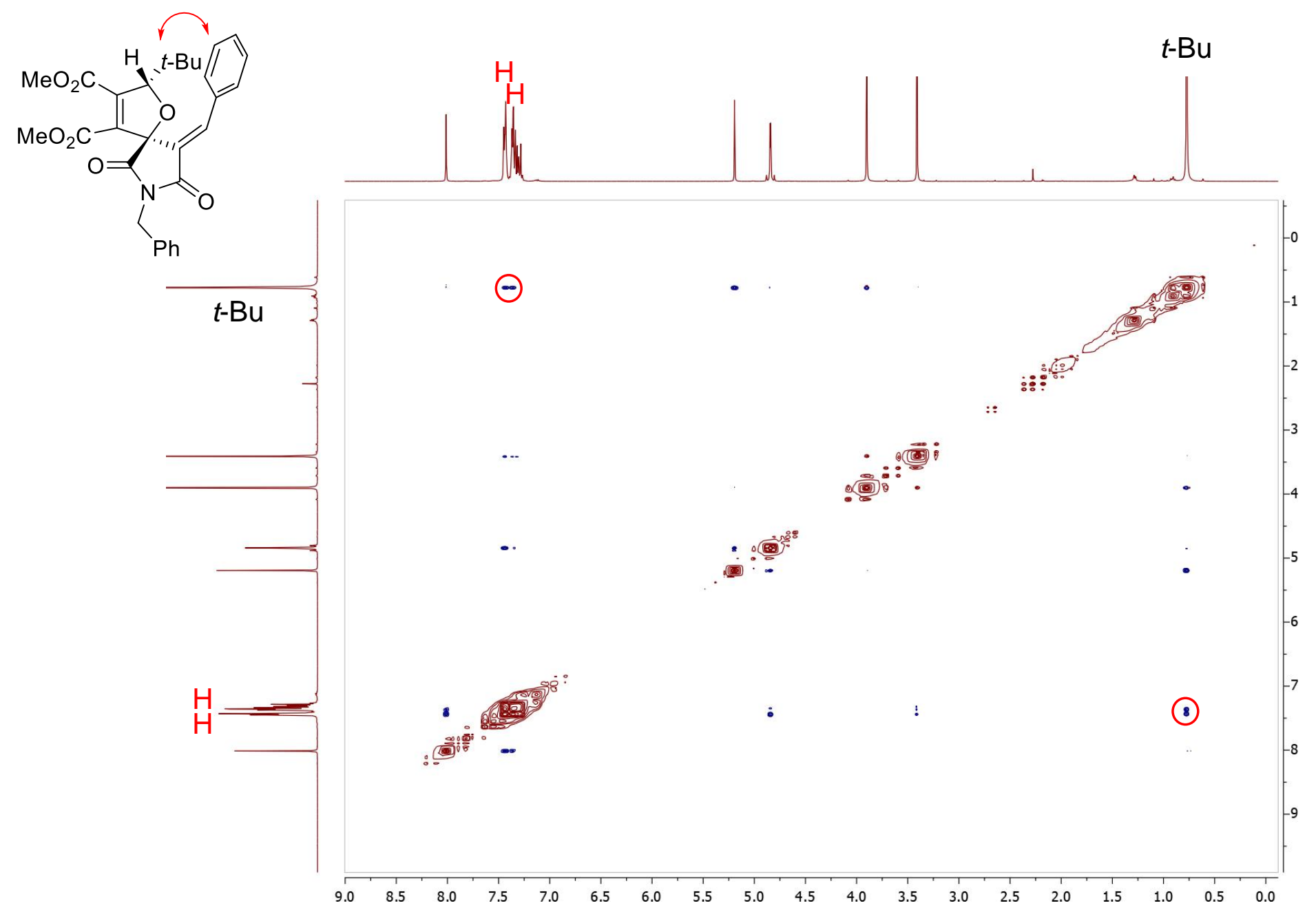

